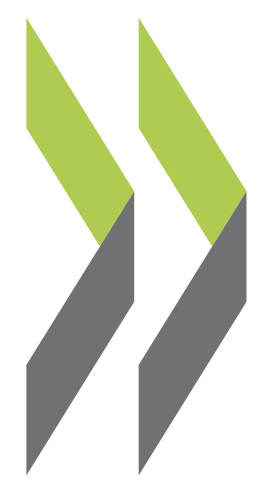

OECD Science, Technology and Industry Working Papers $2013 / 04$

\title{
Careers of Doctorate
} Holders: Analysis of Labour Market and Mobility Indicators

\section{Laudeline Auriol,}

Max Misu,

Rebecca Ann Freeman 
Organisation de Coopération et de Développement Économiques

Organisation for Economic Co-operation and Development

05-Nov-2013

DIRECTORATE FOR SCIENCE, TECHNOLOGY AND INDUSTRY

English - Or. English

CAREERS OF DOCTORATE HOLDERS: ANALYSIS OF LABOUR MARKET AND MOBILITY INDICATORS

STI Working Papers 2013/4

By Laudeline Auriol, Max Misu and Rebecca Freeman (OECD)

Complete document available on OLIS in its original format

This document and any map included herein are without prejudice to the status of or sovereignty over any territory, to the delimitation of international frontiers and boundaries and to the name of any territory, city or area. 


\section{STI WORKING PAPER SERIES}

The Working Paper series of the OECD Directorate for Science, Technology and Industry is designed to make available to a wider readership selected studies prepared by staff in the Directorate or by outside consultants working on OECD projects. The papers included in the series cover a broad range of issues, of both a technical and policy-analytical nature, in the areas of work of the DSTI. The Working Papers are generally available only in their original language - English or French - with a summary in the other.

Comments on the papers are invited, and should be sent to the Directorate for Science, Technology and Industry, OECD, 2 rue André-Pascal, 75775 Paris Cedex 16, France.

The opinions expressed in these papers are the sole responsibility of the author(s) and do not necessarily reflect those of the OECD or of the governments of its member countries.

www.oecd.org/sti/working-papers

OECD/OCDE, 2013

Applications for permission to reproduce or translate all or part of this material should be made to: OECD Publications, 2 rue André-Pascal, 75775 Paris, Cedex 16, France; e-mail: rights@oecd.org 


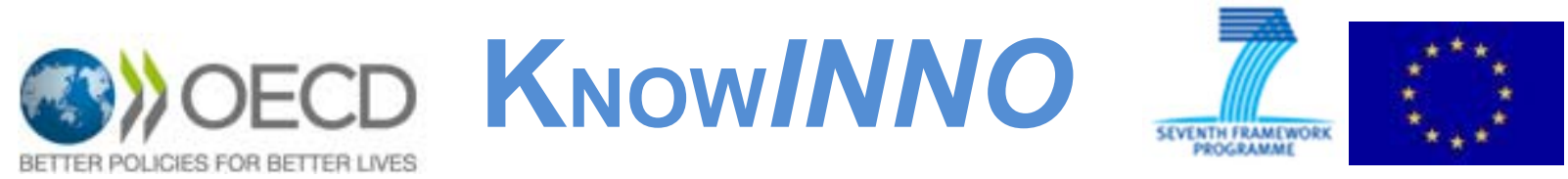

Making the most of knowledge

\title{
CAREERS OF DOCTORATE HOLDERS: ANALYSIS OF LABOUR MARKET AND MOBILITY INDICATORS
}

Laudeline Auriol, Max Misu and Rebecca Freeman, OECD

\begin{abstract}
This paper presents an analysis of the labour market and mobility indicators generated by the second large-scale data collection on Careers of Doctorate Holders (CDH), a joint project by the OECD, UNESCO Institute for Statistics and Eurostat ${ }^{1}$.

There has been a steady increase in the number of doctoral degrees being awarded across the OECD and the evidence points to a sustained labour market premium of doctorate holders relative to other highly qualified individuals in 2009, prior to the potential impact of the economic crisis. Women and younger doctoral graduates, however, fare relatively worse in terms of employment rates, but these results are less marked than for lower degree holders. While temporary positions are increasingly common in academics, coinciding with the rise of postdoctoral positions, they are less so in business. Natural scientists and engineers are those who are more likely to be engaged in research, while social scientists find more opportunities in non-research occupations. Doctorate holders in the medical and health sciences are generally better paid. Earnings are also typically higher in the business sector than in other sectors, but there are exceptions. Job mobility patterns differ markedly across countries, with mobility being more frequent among doctorates not working in research. Oftentimes mobility from the business sector to the higher education sector is higher than the other way around. International mobility, as well as migration of doctoral graduates, have kept increasing over the decade.
\end{abstract}

1. This analysis, carried out in 2011-12, has partly been financed by the European Commission (DG Research and Innovation) as part of the FP7 Programme. It has greatly benefitted from comments by the participants in the project and in the final conference held on 3 December 2012 in Brussels. 


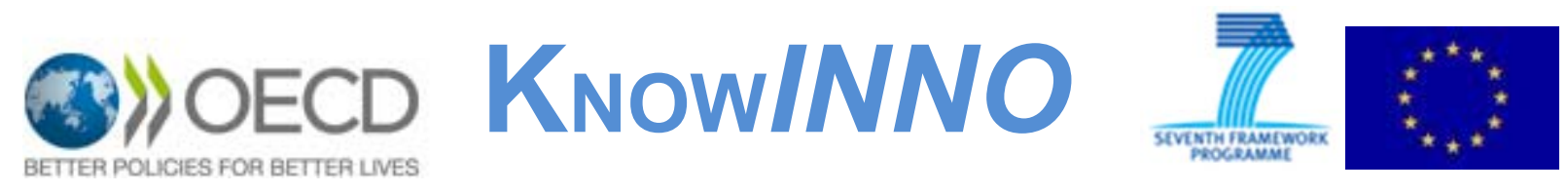

Making the most of knowledge

\title{
LES CARRIÈRES DES TITULAIRES DE DOCTORAT : ANALYSE DES INDICATEURS DU MARCHÉ DU TRAVAIL ET DE LA MOBILITÉ
}

\section{Laudeline Auriol, Max Misu and Rebecca Freeman, OCDE}

\begin{abstract}
RÉSUMÉ
Ce document présente une analyse des indicateurs du marché de du travail et de la mobilité résultant de la seconde collecte de données de grande échelle sur les Carrières des Titulaires de Doctorat (CTD), un projet conjoint de l'OCDE, de l'Institut Statistique de l'UNESCO et d'Eurostat ${ }^{2}$.

Le nombre de diplômes de doctorat décernés augmente de façon continue dans les pays de l'OCDE et les résultats montrent un avantage des titulaires de doctorat sur le marché du travail comparé aux autres individus qualifiés en 2009, ceci avant les éventuels effets de la crise économique. Les femmes et les plus jeunes parmi les diplômés de doctorat, affichent néanmoins de moins bonnes performances en termes de taux d'emplois, mais ces tendances sont moins marquées qu'à des niveaux de diplôme inférieurs. Tandis que les postes à durée déterminée sont de plus en plus fréquents dans le secteur de l'enseignement supérieur, ce qui coïncide avec l'augmentation des 'postdocs', les emplois temporaires sont moins courants dans les entreprises. Les spécialistes des sciences exactes, naturelles et de l'ingénieur sont ceux qui sont le plus susceptibles d'être embauchés dans la recherche tandis que les spécialistes des sciences sociales ont davantage d'opportunités dans d'autres professions. Les titulaires de doctorat en médecine et autres disciplines de santé sont en général les mieux rémunérés. Les revenus sont aussi plus élevés dans le secteur des entreprises, mais il existe des exceptions. Les situations au regard de la mobilité d'un emploi à l'autre varient entre pays mais la mobilité est davantage répandue parmi les diplômés de doctorat ne travaillant pas dans la recherche. Les mouvements du secteur des entreprises vers celui de l'enseignement supérieur sont plus fréquents que l'inverse. La mobilité internationale et les mouvements migratoires des titulaires de doctorat ont continué d'augmenter au cours de la décennie.
\end{abstract}

2. Cette analyse, menée en 2011-12, a été en partie financée par la Commission Européenne (DG Recherche et Innovation) dans le contexte du $7^{\mathrm{e}}$ Programme Cadre. Elle a grandement bénéficié des commentaires des participants au projet, ainsi qu'à la conférence finale qui s'est tenue le 3 décembre 2012 à Bruxelles. 


\section{TABLE OF CONTENTS}

ABSTRACT

CAREERS OF DOCTORATE HOLDERS: ANALYSIS OF LABOUR MARKET AND MOBILITY

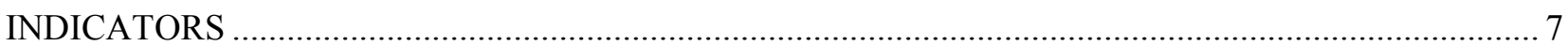

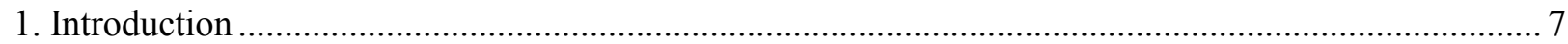

2. Increasing flow of new graduates and share of doctorates in the population...................................... 8

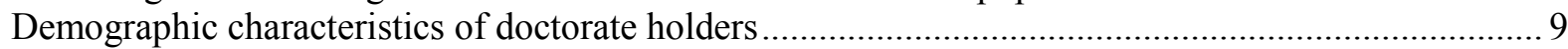

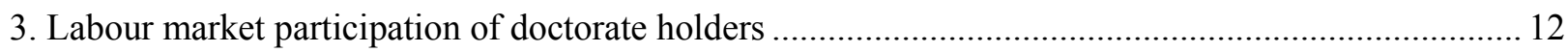

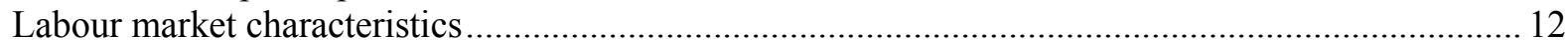

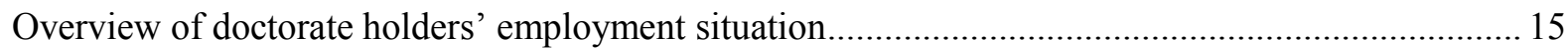

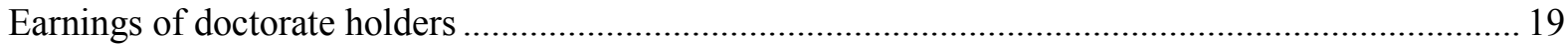

Doctorate holders' perception of their professional positions ........................................................ 21

4. Career as a researcher and attractiveness of research careers …................................................... 22

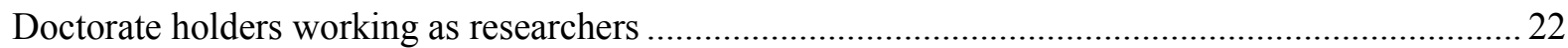

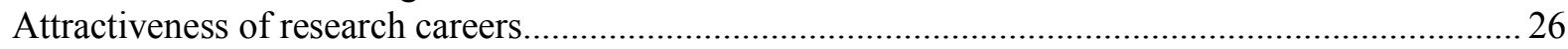

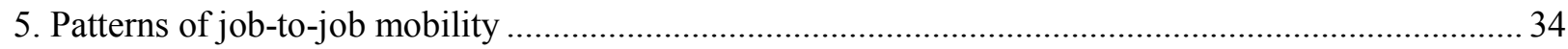

6. International mobility and the competition for talent ........................................................................ 37

Mobility and emigration of doctorate holders to the United States ................................................. 42

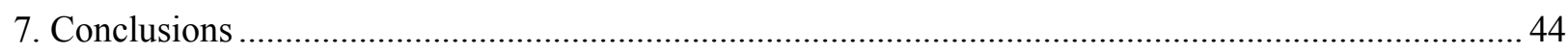

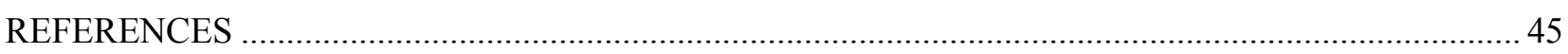

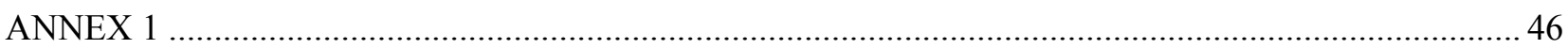

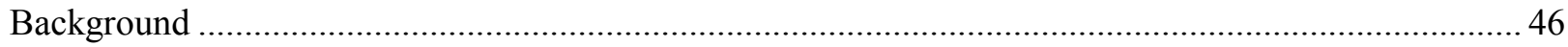

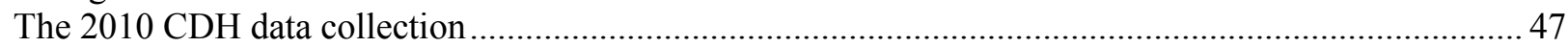

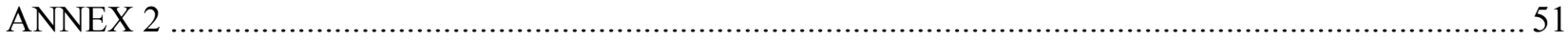

\section{Boxes}

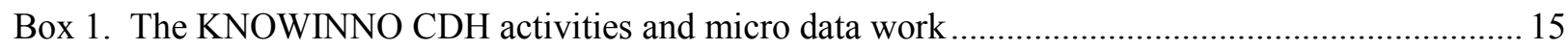

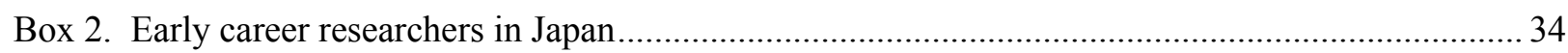

Box 3. The Database on Immigrants in OECD Countries...................................................................... 41 


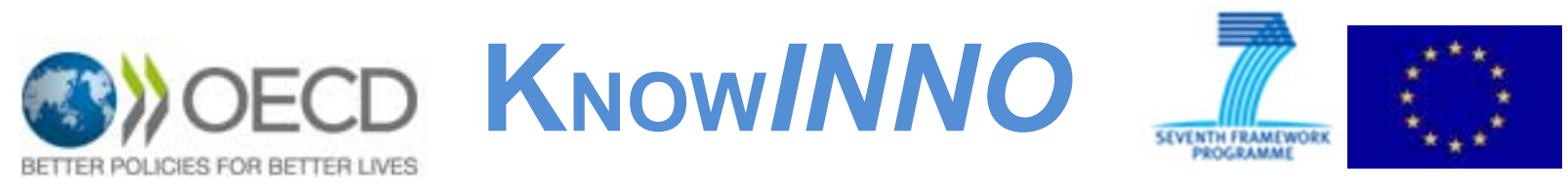

Making the most of knowledge

\section{CAREERS OF DOCTORATE HOLDERS: ANALYSIS OF LABOUR MARKET AND MOBILITY INDICATORS}

\section{SUMMARY OF KEY FINDINGS}

- The past decade has witnessed a steady increase in the number of doctoral degrees being awarded across the OECD, rising by 38\% from 154000 new doctoral graduates in 2000 to 213000 in 2009.

- There is only a weak association between the proportion of doctor graduates in the labour force and a country's R\&D intensity. Switzerland has the highest workforce share of doctorates, close to 2.8 per cent.

- Despite the growing supply of doctorates, the available evidence points to a sustained -possibly increasing- labour market premium on individuals holding doctoral qualifications, relative to other highly qualified individuals.

- Although female and younger doctorate holders fare relatively worse in terms of employment rates than their older and male counterparts, these biases are less marked for doctorate holders than for individuals with lower levels of educational attainment.

- Employment rates for recent doctorates are also high, but figures for 2009 still do not account for the wave of fiscal adjustment in many countries and its potential impact on the public funding of R\&D. Temporary positions are increasingly common in the academic sector, but less so in business.

- Although the higher education sector is the main sector of employment for doctorates, demand for doctorates is apparent across other sectors of the economy. The take up of jobs outside higher education is not necessarily, but often related to take-up of non research occupations.

- Natural scientists and engineers are more likely to be engaged in research while social scientists find more opportunities in non-research occupations.

- Job mobility patterns differ markedly across countries but mobility is more frequent among doctorates not working in research. Very few countries have more mobility from the higher education to the business sector than vice versa.

- Earnings in agricultural sciences and humanities are below the overall median in most countries, whereas doctorate holders in medical and health sciences tend to be paid above. Doctorates in the business sector are typically better paid than in other sectors, but not in all countries.

- International mobility is a widespread and increasingly important phenomenon, although less common than it might be assumed for researchers.

- Even when not in research, jobs are in most cases related to the subject of doctoral degrees and doctoral graduates are satisfied with their employment situation. A wide range of monetary and non pecuniary factors contribute to explaining the reported attractiveness of research careers. Satisfaction levels on aspects other than pay are particularly high for individuals working in research. 


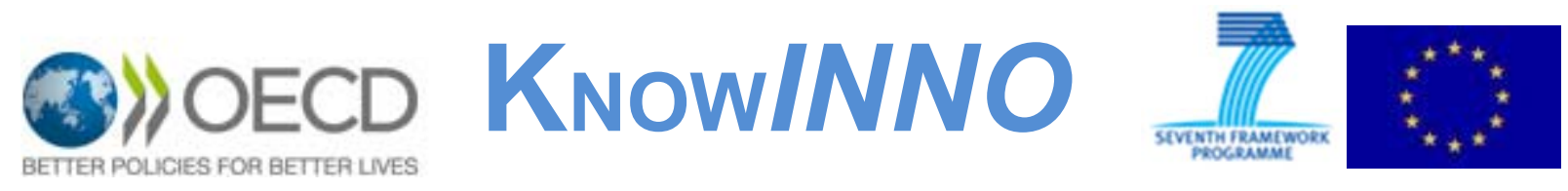

Making the most of knowledge

\title{
CAREERS OF DOCTORATE HOLDERS: ANALYSIS OF LABOUR MARKET AND MOBILITY INDICATORS
}

\author{
Laudeline Auriol, Max Misu and Rebecca Freeman, OECD
}

\section{Introduction}

1. Doctoral graduates account for a relatively small proportion of the overall population but their importance is widely appreciated (OECD, 2010). Having benefitted from highly specialised research training and produced an original contribution to science, doctoral holders are expected to play a key role in the knowledge economy as they stand in a position to drive forward advances in science, technology and knowledge about society. Evidence on the careers of doctorate holders $(\mathrm{CDH})$ and their contribution to science, innovation and the economy is of high relevance not only to policy decision makers and governments who finance the training of this group of individuals and support their integration in the innovation system; but also to prospective employers in search of specific skills for their workforce; and the individuals themselves who consider whether to pursue doctorate studies and proceed with research or unrelated careers. Unfortunately, evidence is limited and sparse owing, for example, to the fact that standard statistical sources are typically far too small to produce statistically robust results for this population. The CDH-KNOWINNO project stems from a relatively recent initiative initiated by the OECD, the UNESCO Institute for Statistics and Eurostat under which internationally co-ordinated data collections have been carried out among participating countries to obtain statistically reliable data on doctorate holders and their professional careers.

2. This paper ${ }^{3}$ provides an overview of the key statistical and analytical findings that draw on data from the second international CDH data collection conducted in 2010, as well as some complementary sources. This paper also analyses the labour market and employment patterns of doctorate holders. Then, it looks at an important specificity of the doctoral job market, which is employment in research. Finally, it studies another marked property of the doctoral population, which is their mobility both across sectors and at the international level. Annex 1 provides further details on the description and methodology of the project.

3. The statistical data for Israel are supplied by and under the responsibility of the relevant Israeli authorities. The use of such data by the OECD is without prejudice to the status of the Golan Heights, East Jerusalem and Israeli settlements in the West Bank under the terms of international law. 


\section{Increasing flow of new graduates and share of doctorates in the population}

3. The past decade has witnessed the continued development of higher education and research systems worldwide. The expansion of higher education has resulted in not only a massive increase of tertiary level graduates but also marked increases in the number of individuals with postgraduate degrees, including doctorate awards In 2009, around 213000 new doctoral graduates graduated from universities in OECD countries, an increase of $38 \%$ with respect to the 154000 who graduated in 2000 .

Figure 1. Graduation rates at doctoral level 2000 and 2009

As a percentage of population in reference age cohort

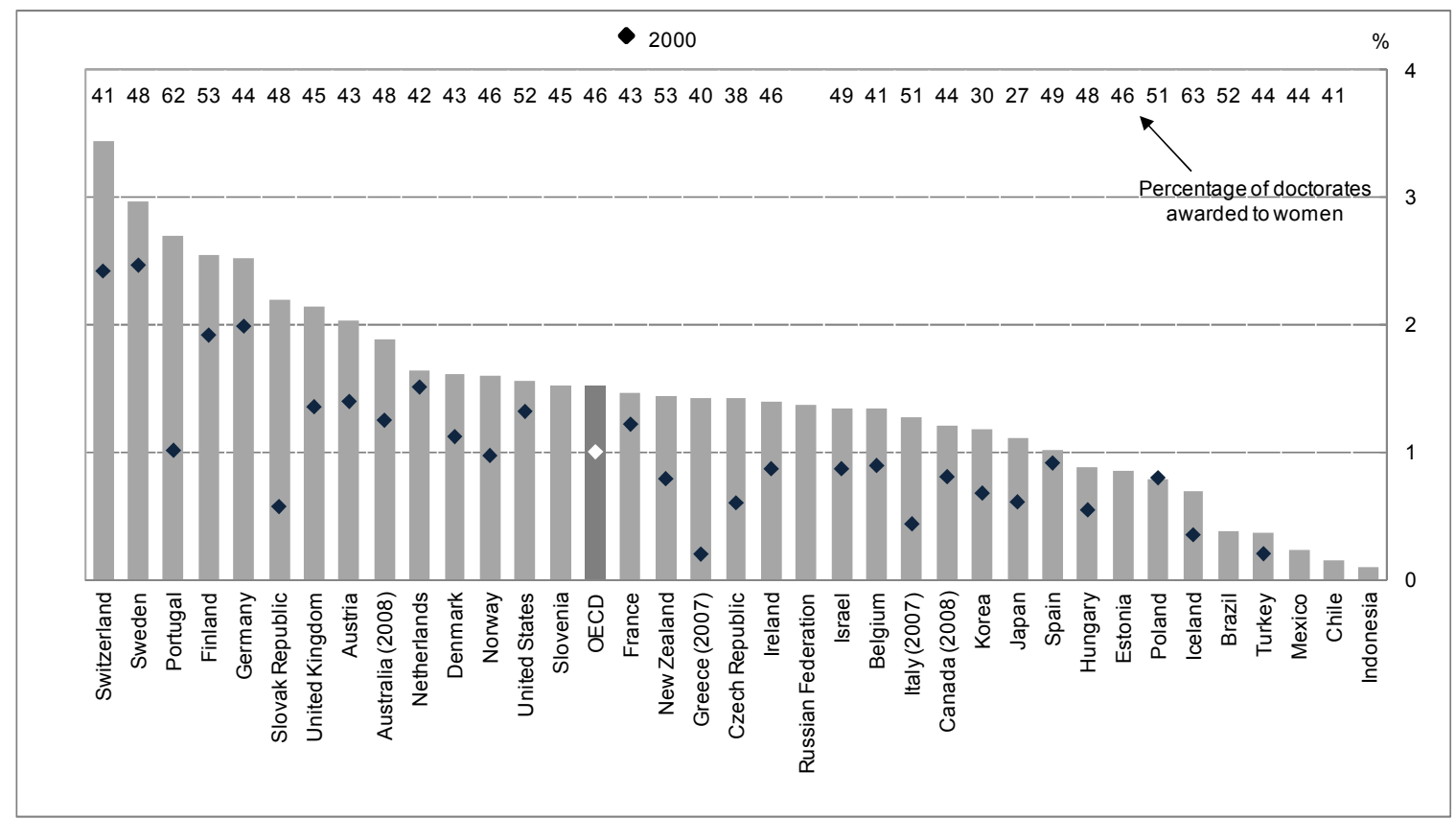

Source: OECD (2011), Education at a Glance 2011: OECD Indicators and (2009) Education at a Glance 2009: OECD Indicators, OECD, Paris.

4. Figure 1 shows that nearly 1.5 per cent of individuals in a comparable age cohort received a doctoral degree, a figure as high as 3.4\% in Switzerland and 3\% in Sweden. The increasing presence of women in doctoral programmes partly explains the overall increase in doctorates over the past decade. Women were awarded on average almost half (46\%) of OECD's new doctorate degrees.

5. There are rather marked differences in the doctorate intensity of labour markets across countries. The high performance of Switzerland in terms of doctoral training is reflected in estimates of the stock of doctorate holders in the total population and labour force (Figure 2). Luxembourg shows a similar pattern due the presence of a large share of foreign doctoral graduates. Germany, the United States and the United Kingdom also display particularly high shares of doctoral graduates, with doctorates respectively accounting for 1.4, 1.3 and 1.2 per cent of the total labour force. 
Figure 2. Doctorate holders per thousand total population and per thousand total labour force 2009

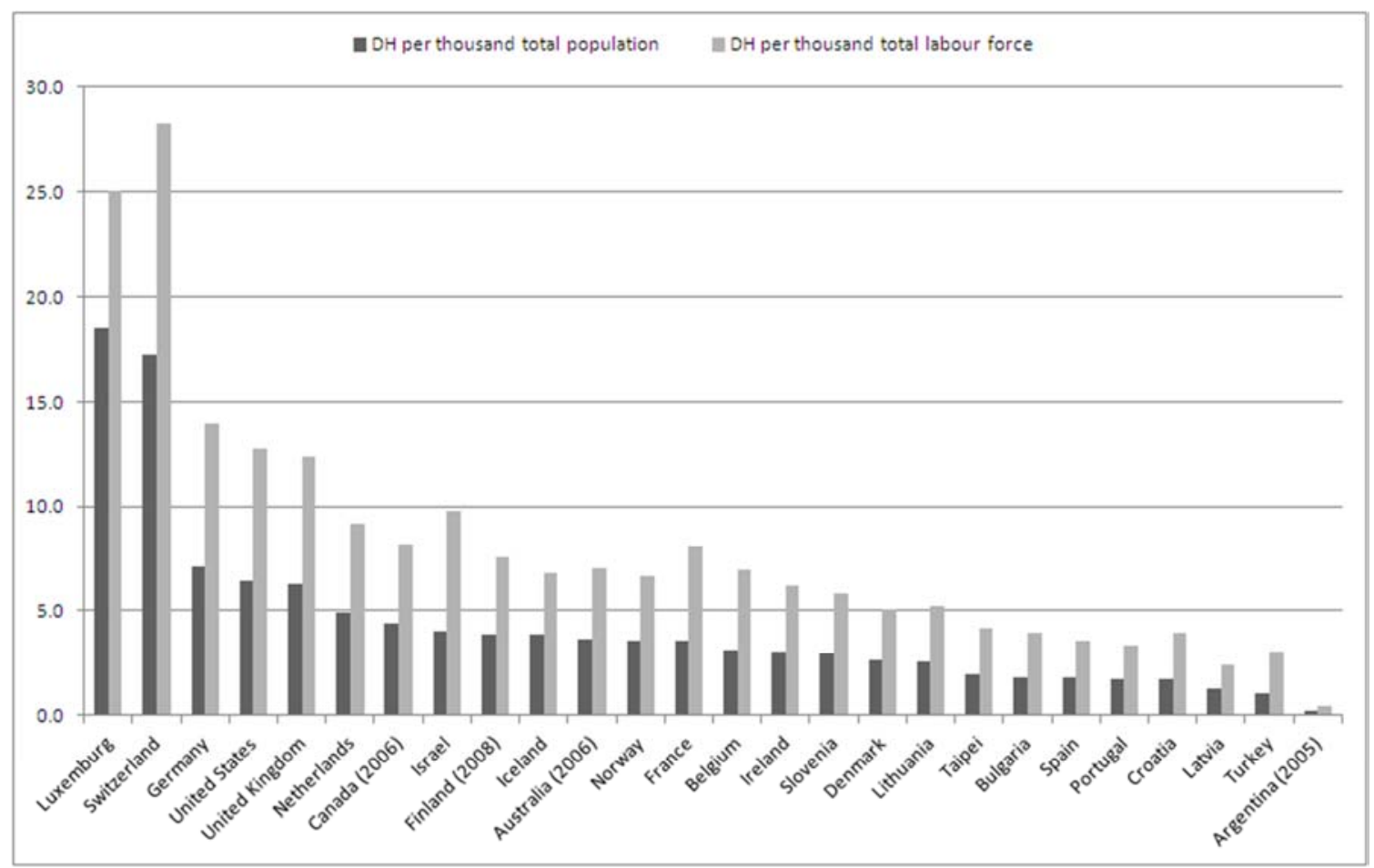

Notes:

*Data for the Netherlands and Spain refer to graduation years 1990 onwards. .For Spain, there is limited coverage of doctorate holders for the years 2007 to 2009.

*Data for Chinese Taipei only include those PhD in National Profiles of Human Resources in Science and Technology (NPHRST) made by STPI, NARL, Chinese Taipei (http://hrst.stpi.narl.org.tw/index.htm\#noticeChinese).

Source: OECD, based on OECD/UNESCO Institute for Statistics/Eurostat data collection on careers of doctorate holders 2010; OECD Main science and technology indicators, OECD Education attainment database, US Census Bureau (ACS, 2009).

\section{Demographic characteristics of doctorate holders}

6. Demographic characteristics of doctorate holders are influenced by the length of doctoral education. In the best case, a full time student will get its doctoral degree after at least eight years of study (five years for a master degree plus three years for a doctoral degree). In practice, this will however vary according to different factors such as duration of programmes, available funding during education, field of study and other personal and unpredicted factors. Some students will also interrupt their studies between a bachelor and master degree or a master and doctoral degree to get a professional experience.

7. A look at the age at doctoral graduation (Figure 3) reveals wide variations across countries, as well as across fields of doctorate. Median age at graduation is generally comprised between 30 and 35 years old. The lowest median age is found in Belgium (27 years old ) while the highest are in Croatia, Israel, Romania, Bulgaria, Latvia and Malta (36 and above). In general, median age at doctoral graduation is lowest in the natural sciences and engineering and highest in the humanities. 
Figure 3. Median age at graduation of recent doctorate recipients 2009

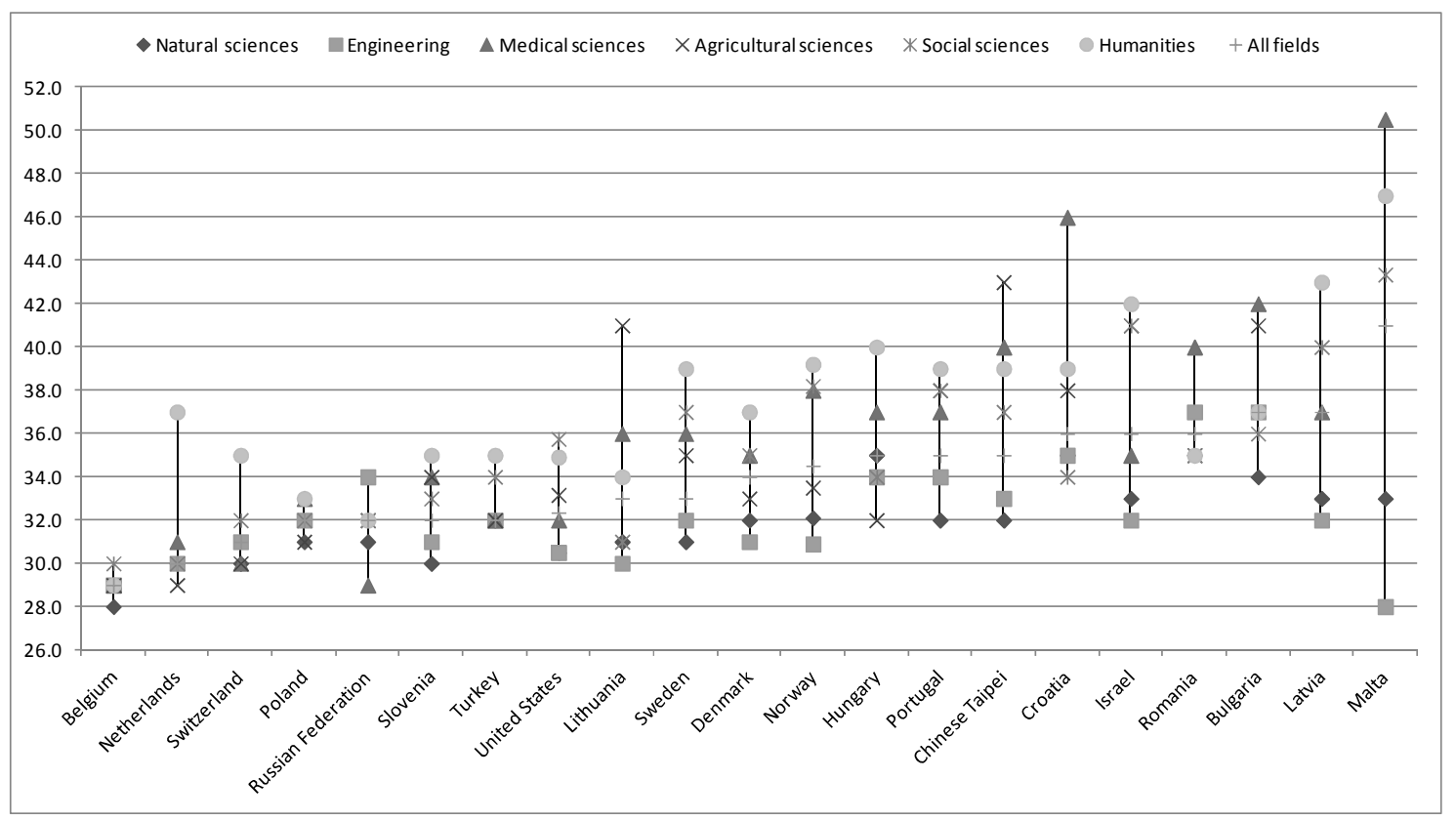

Notes:

*For Spain, there is limited coverage of doctorate holders for the years 2007 to 2009.

*Data for Chinese Taipei only include those PhD in National Profiles of Human Resources in Science and Technology (NPHRST) made by STPI, NARL, Chinese Taipei (http://hrst.stpi.narl.org.tw/index.htm\#noticeChinese).

Source: OECD, based on OECD/UNESCO Institute for Statistics/Eurostat data collection on careers of doctorate holders 2010.

8. Consequently, doctoral graduates arrive late on the labour market and this is reflected in the structure of the population (Figure 4). At least $30 \%$ of doctorate holders are less than 45 years old, but in the majority of the countries at least $20 \%$ are also more than 55 years old and may retire in the next ten years. In Bulgaria, Russia, Israel and Latvia, it is more than 35\% who are above 55 years old. In Israel and Russia, this situation is associated with graduation rates at the doctoral level that are lower than the OECD average (Figure 1), while in Bulgaria, Israel and Latvia this is combined with a relatively high age at graduation as mentioned above. In the medium and long term, these patterns could have a negative effect on the research capabilities of these nations.

9. The continued progression in the number of doctoral degree awards could however offset this situation. In particular, the already mentioned increased women participation has a clear impact on the age structure of the population in all the economies for which data are available as may be seen from Figure 5. There is still room for improvement on this aspect since women remain generally underrepresented in the doctoral population. In 2009, they represented less than $40 \%$ of total doctorate holders in 13 out of the 22 countries shown in Figures 4 and 5. 
Figure 4. Age distribution of total doctorate holders, 2009 As a percentage of total doctorate holders

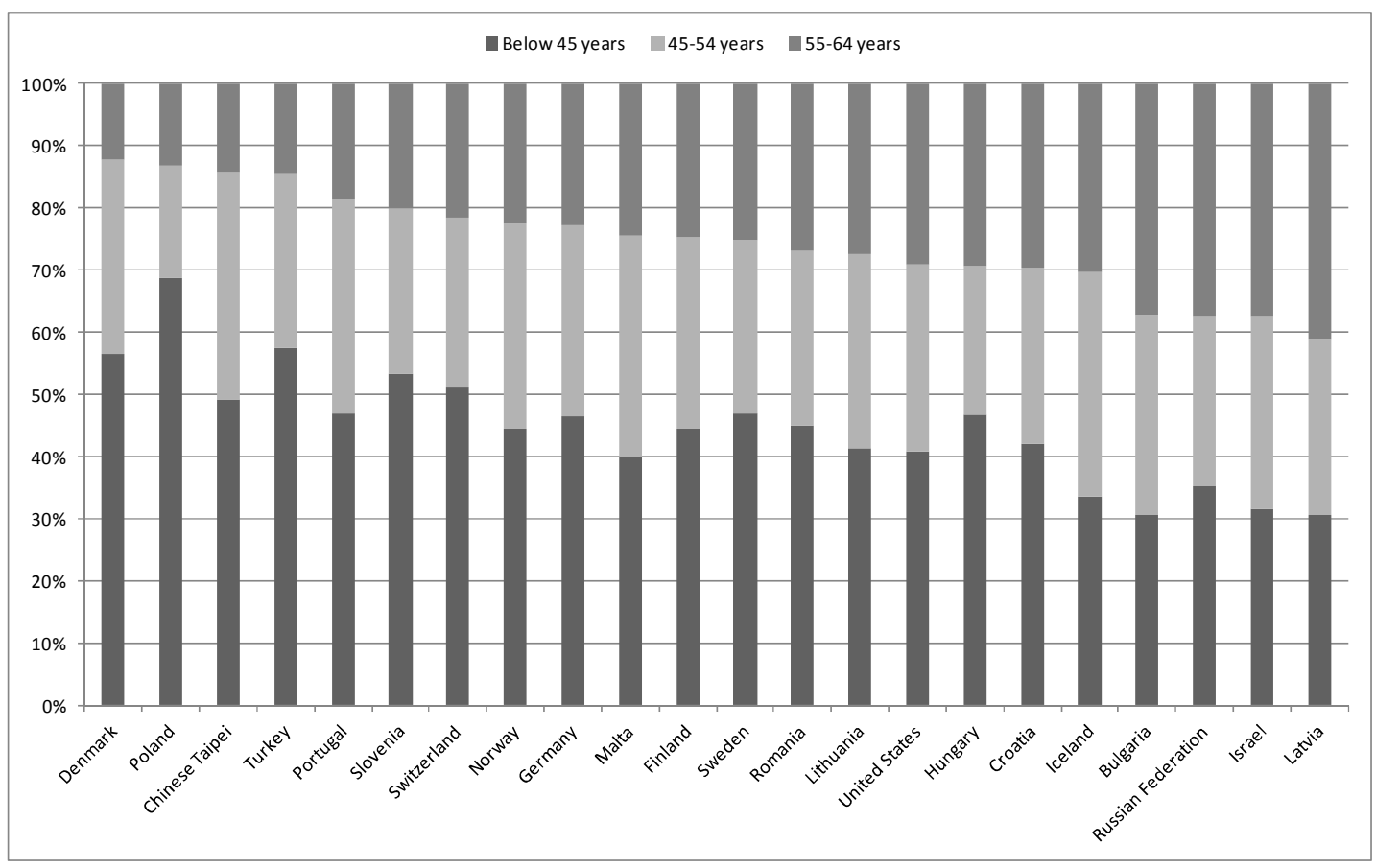

Figure 5. Share of doctorate holders below 45 years old, 2009

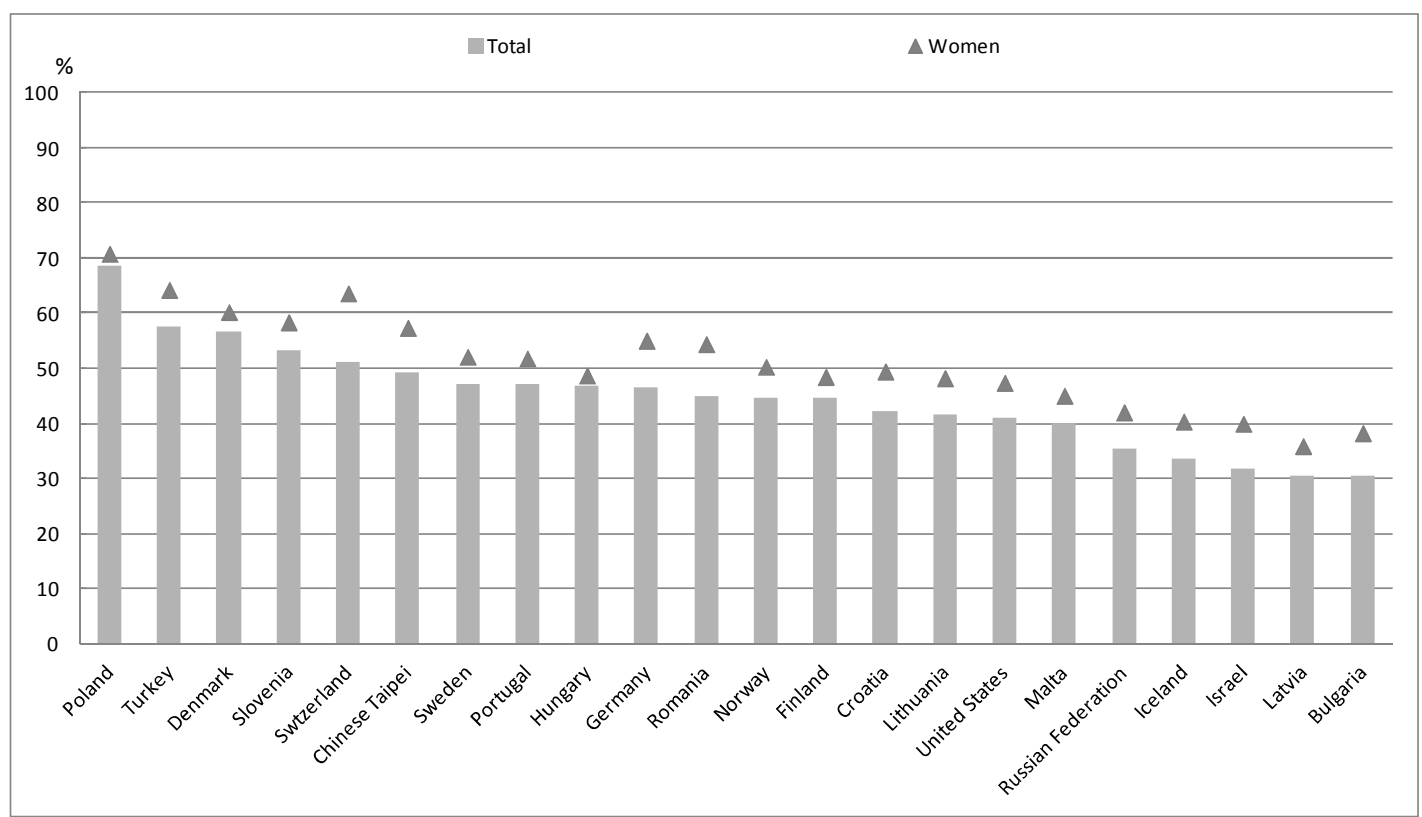

Notes:

*Data for Sweden are for the total employed population only.

*Data for Chinese Taipei only include those PhD in National Profiles of Human Resources in Science and Technology (NPHRST) made by STPI, NARL, Chinese Taipei (http://hrst.stpi.narl.org.tw/index.htm\#noticeChinese).

*Data for Turkey exclude foreign citizens.

*For the United States, data exclude doctorate holders who received their degree abroad and who received a doctorate in humanities.

Source: OECD, based on OECD/UNESCO Institute for Statistics/Eurostat data collection on careers of doctorate holders 2010. 


\section{Labour market participation of doctorate holders}

10. Despite reported concerns in the media about excessive graduation rates and claims that advanced skills are being underutilised, there is no evidence to suggest that the growth in the number of individuals at the highest level of qualification has resulted in some form of excess supply that the labour market struggles to accommodate. Most indicators point to a sustained, if not increasing premium on doctorate skills, which is consistent with rising demand for individuals with such skills. A considerable body of literature has shown that labour market outcomes improve with the level of education. Comparisons between doctorate holders and other individuals at the upper end of the educational attainment distribution should always take into account possible differences in competencies and skills that are not attributable to the pursuit of additional education and the role these play in driving education and future labour market participation decisions.

11. This section describes the labour market situation of doctorate holders, placing it in the broader context of that for tertiary graduates where possible. It starts with a broad overview of principal labour market indicators, and then addresses more specific questions on occupational status, contract duration and type, sector of employment, and field of study. Earnings and earnings differentials between male and female doctorate holders are also considered, followed by a review of doctorate holder's perception regarding the relation of their current job to their doctorate degree and an overview of their satisfaction level by various criteria.

\section{Labour market characteristics}

12. Comparing $\mathrm{CDH}$ statistics with standard labour force statistics, individuals with doctoral degrees had higher employment rates than the average higher education graduates in 2009, which confirms the findings based on the first CDH data collection back in 2006, prior to the onset of the economic crisis. Due to differences in survey design, comparisons across different databases are hazardous and therefore differences may not be as large as implied by the chart. However, this result is replicated across countries with surveys that cover the broad set of higher education graduates.

13. The average employment rate of male and female doctorate holders who obtained their degrees after 1970 is $93 \%$, compared to $81 \%$ for all tertiary graduates aged 25 to 69 within the economies for which data are available (Figure 6). The high employment rate found among doctorate holders compared to other tertiary graduates signals the attractiveness of this group as job market candidates and underscores the employment premium linked to doctoral education, even in times of economic downturn. The difference between the employment rate for doctoral graduates and that for all tertiary level graduates is particularly marked for Croatia, Hungary, Poland and Turkey. In most economies, male employment rates slightly exceed those of females. Exceptions are found for Chinese Taipei, Bulgaria, Finland and Malta. For Malta, the female employment rate exceeds that for males by 6 percentage points. Economies in which male employment rates most exceed those of females include Germany ( 8 percentage points), Hungary (5 percentage points) and Israel (6 percentage points). 
Figure 6. Employment rate of doctorate holders by gender, 2009 As a percentage of total doctorate holders

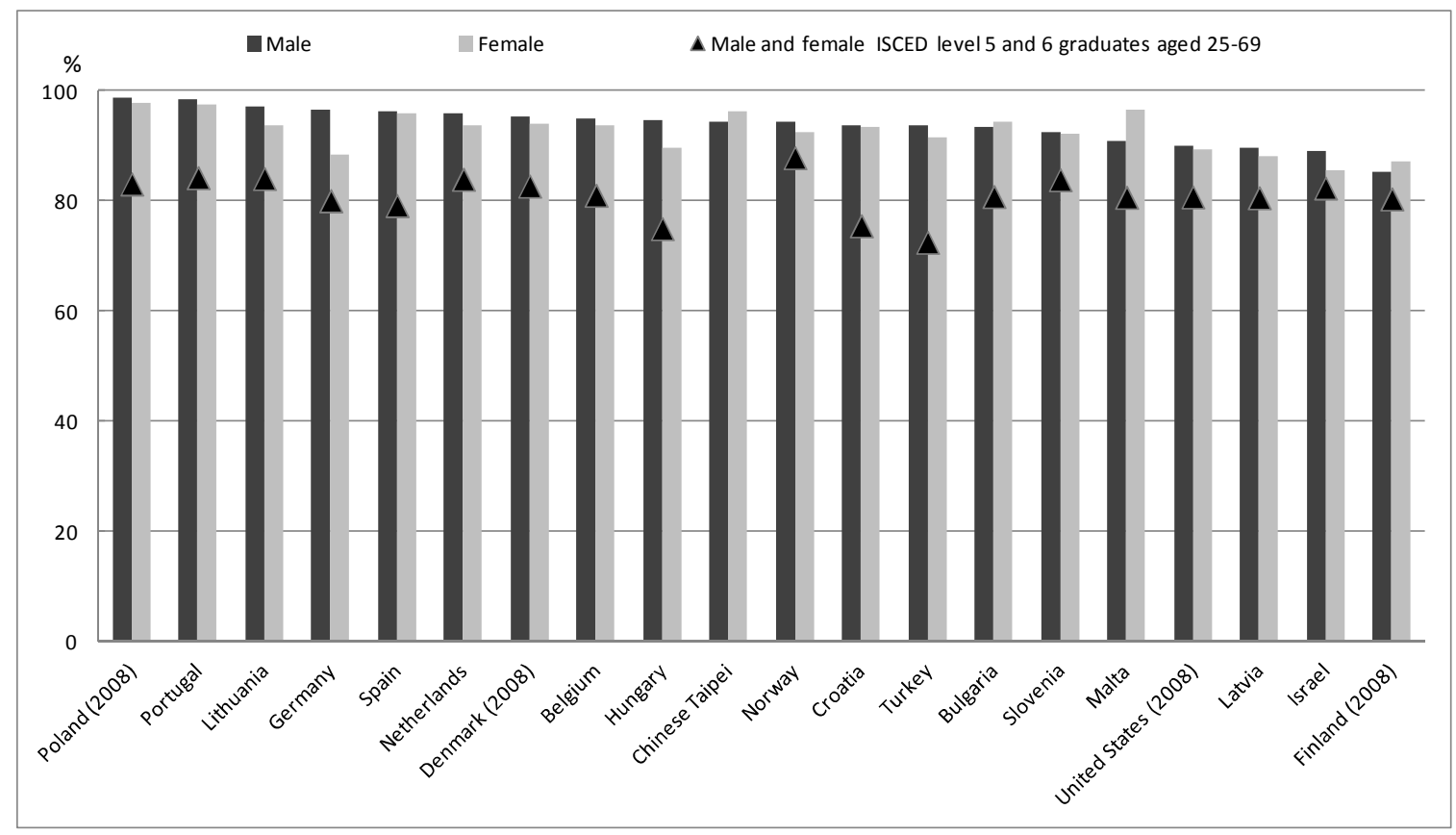

Notes:

*Data for Belgium, Germany, Hungary, the Netherlands and Spain refer to graduation years 1990 onwards.

*For Belgium and Malta, data for the 65-69 age class include doctorate holders aged 70 years and above.

*For Spain, there is limited coverage of doctorate holders for the years 2007 to 2009.

*Data for Chinese Taipei only include those PhD in National Profiles of Human Resources in Science and Technology (NPHRST) made by STPI, NARL, Chinese Taipei (http://hrst.stpi.narl.org.tw/index.htm\#noticeChinese).

*Data for Turkey exclude foreign citizens.

*For the United States, data exclude doctorate holders who received their degree abroad and who received a doctorate in humanities.

Source: OECD, based on OECD/UNESCO Institute for Statistics/Eurostat data collection on careers of doctorate holders 2010; Eurostat 2012; Education at a Glance 2012.

14. The position of recent doctoral graduates may be less favourable than for those who have received their doctorate a longer time ago. Unemployment rates of doctoral graduates actually vary both throughout their career paths and depending on field of study. Indeed, as highlighted in Figure 7, unemployment rates among total doctoral graduates do not exceed $2 \%$ when all time periods are considered but are typically higher in the first five years after graduation. Exceptions are found for Chinese Taipei, Croatia, Germany, Latvia and Lithuania. This may be the sign of a higher demand for new doctoral graduates in these economies. Data through 2008 for the United States indicate that the unemployment rate is unaffected by the amount of time that has passed since completion of one's doctorate. Annex table 1 also shows that there is a higher share of unemployed women in the population of doctorate holders that men in 13 out of the 19 economies for which data are available as well as a higher share of inactive women that men in 15 economies. The average unemployment rate for total graduates at the doctorate level is roughly three percentage points lower than that for other tertiary level graduates aged 25 to 64 for the economies for which data are available, confirming the already well established fact that employment prospects improve with the level of degree. 
Figure 7. Unemployment rates of doctorate holders over career path, 2009 As a percentage of total doctorate holders

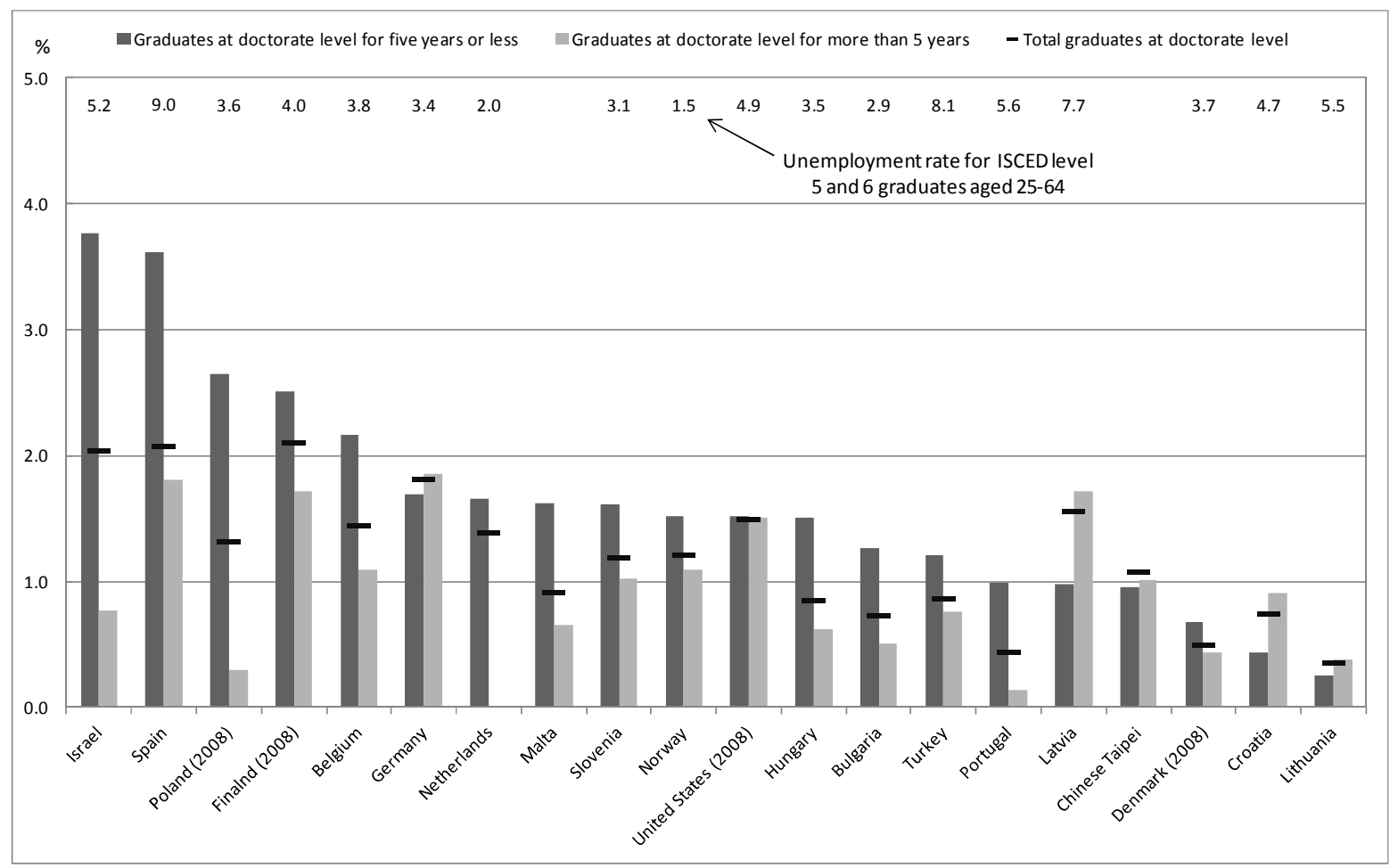

Notes:

*Data for Belgium, Germany, Hungary, the Netherlands and Spain refer to graduation years 1990 onwards.

${ }^{*}$ For Belgium and Malta, data for the 65-69 age class include doctorate holders aged 70 years and above.

*For Spain, there is limited coverage of doctorate holders for the years 2007 to 2009.

*Data for Chinese Taipei only include those PhD in National Profiles of Human Resources in Science and Technology (NPHRST)

made by STPI, NARL, Chinese Taipei (http://hrst.stpi.narl.org.tw/index.htm\#noticeChinese).

*Data for Turkey exclude foreign citizens.

*For the United States, data exclude doctorate holders who received their degree abroad and who received a doctorate in humanities.

Source: OECD, based on OECD/UNESCO Institute for Statistics/Eurostat data collection on careers of doctorate holders 2010; Eurostat 2012; Education at a Glance 2012.

15. A noticeable exception to this is the case of France. While this country does not participate in the $\mathrm{CDH}$ project, there exist in France first destination surveys allowing comparison of the labour market outcome of doctoral graduates with that of other degree holders three years after graduation ${ }^{4}$. The data show that, in contrast to the pattern in the other countries, unemployment rates of French doctoral graduates three years after receipt of their degree were higher than for graduates at lower level of education during the 2000s (see Harfi and Auriol 2010). The latest survey however shows that this is not the case anymore in 2010 although graduates from engineering schools fare better on the labour market (Calmand and Vera 2011). Indeed, it would seem that the French dual education system has an impact on the labour market outcome of those graduated from universities compared to those from the so-called 'grandes écoles' (higher schools). Still, the 2010 unemployment rate of French doctoral graduates three years after the receipt of their doctorate remains high (at 7\%) as compared to that of the other countries as shown from the results of the KNOWINNO-CDH micro data work (Box 1).

4. The so-called 'Enquêtes Générations' conducted in France by the CEREQ (http://www.cereq.fr/). 
16. How do employment prospects vary across fields of doctoral degree? Annex table 2 shows that the unemployment rate is lowest among doctorates having completed their degree in engineering and social sciences, followed by medical sciences. In the natural sciences, unemployment rates remain above the overall unemployment rate of doctorate holders in a majority of countries. Doctorate holders in humanities exhibit the highest unemployment rates compared to other fields of study. Nonetheless, differences in unemployment rates among doctorates from all fields of study remain minor. One exception is the unemployment rate for doctorate holders who studied agricultural sciences in Israel. The unemployment rate for this particular group is 9.9 percent, compared to an average of 1.4 percent for all other economies for which there are data.

\section{Box 1. The KNOWINNO CDH activities and micro data work}

Over the 2011-2012 biennium, the OECD activity on CDH has been partly sponsored by the European Union's Seventh Framework Programme as part of the broad OECD KNOWINNO project. This supported the development of the CDH database by the OECD and has helped produce a set of internationally-comparable indicators based on the results from the $2010 \mathrm{CDH}$ data collection. In order to address a number of policy and analytical questions, four key areas of work were identified for detailed investigation: 1) early career of doctorate holders; 2) job-to-job mobility; 3 ) international mobility and 4) competences and skills of doctorate holders. Each topic was led by a participant organisation: NISTEP/Japan for early careers, DGEEC/Portugal for job-to-job mobility, CSIC/Spain for international mobility and ECOOM/University of Ghent/Belgium for competences and skills.

In order to extend the number of countries for which comparisons could be carried out, a special effort was made to define common populations of doctorate holders among surveys of university graduates available for France, Japan and the United Kingdom, and subsamples within CDH surveys carried out in other countries. Access to and use of micro data has been instrumental in facilitating these comparisons that were carried out under the "early career module" of the project. Using a data coding guide provided by the OECD, ten volunteer countries harmonised their micro data sets in order to implement tabulations and econometric analyses using a common programming code developed by CSIC and NISTEP. The OECD secretariat also carried out for demonstration purposes a comparative analysis of micro data on doctorate holders and individuals holding other postgraduate qualifications for the United States and the United Kingdom.

\section{Overview of doctorate holders' employment situation}

17. Despite generally low unemployment rates, the prospects for doctorate holders to obtain indefinite contracts are more uncertain than for all employees in more than half of the economies for which data are available. Indeed, this is the case for Belgium, Germany, the Netherlands, Portugal, Latvia, Lithuania, Malta and Slovenia. Figure 8 shows that the percentage point difference between the share of doctorate holders and all employees under temporary contracts is particularly marked for Portugal (11\%), Latvia (19\%) and Belgium (13\%).

18. One important condition that young doctoral graduates have to meet when choosing a research career is the increasing necessity to occupy at least one, if not several postdoctoral positions. These 'postdocs', which are short-term temporary positions, are in principle aimed at consolidating or improving the research training of new doctorate recipients and prepare them to a research career. They can be the first step in the pipeline leading to a tenured research position at a university lab. The length of these postdoc positions, as well as their frequency and recurrence have however generated concerns with respect to their potential deterring effect on the attractiveness of research careers for a population that has already gone through long academic training and reaches an age at which they legitimately aspire to a more secured position. In some cases, postdoc positions have even been considered as a way to employ cheap research manpower (see for example Science, 2012). 


\section{DSTI/DOC(2013)4}

19. Unfortunately, it proves extremely difficult to measure the 'postdoc' phenomenon. The diversity of contracts both across institutions and across countries, under which postdocs are administered, makes it impossible to come up with a definition that can be operational in a statistical survey. The CDH project however attempts to look at the early career stage of doctoral graduates and finds a higher prevalence of temporary contracts among younger doctorate holders, which may coincide to some extent with the existence of postdoctoral positions.

20. Indeed, graduates at the doctorate level for five years or less have a higher share of temporary contracts than those who received their degree more than five years ago in all economies except Malta. Nonetheless, the share of temporary contracts remains above $12 \%$ in nine out of 16 economies for doctorates who received their degrees more than 5 years ago. The share of doctorates under temporary contracts less than five years after receipt of their degree is particularly high in Portugal (57\%), Germany $(45 \%)$ and the Netherlands (41\%). It is above $23 \%$ for 10 out of the 16 economies. It is interesting to note as well that the incidence of temporary employment differs across fields of study. Cross-country averages reveal that nearly $20 \%$ of doctorate holders are on a temporary contract in Humanities, followed by nearly $16 \%$ in Natural and Social Sciences and 15\% in Medical sciences.

Figure 8. Doctorate holders on temporary contracts over career path, 2009

As a percentage of employed doctorate holders

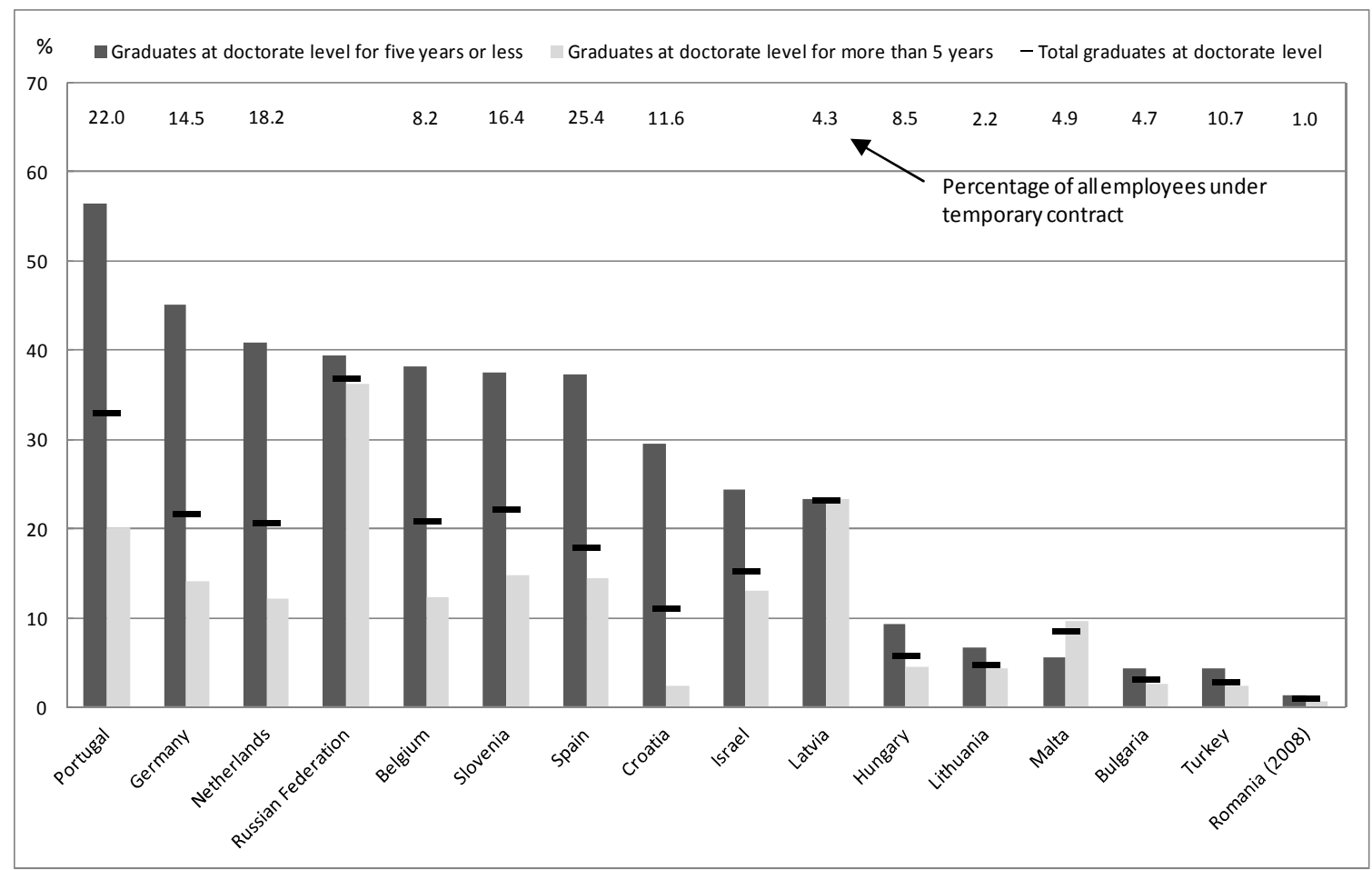

Notes:

*Data for Belgium, Germany, Hungary, the Netherlands and Spain refer to graduation years 1990 onwards.

*For the Netherlands, data refer to employees only.

*For the Russian Federation, data relate only to those doctoral graduates employed as researchers and teachers.

*For Spain, there is limited coverage of doctorate holders for the years 2007 to 2009.

*For Spain, doctorate holders with "unspecified contracts" refer to self-employed.

*Data for Turkey exclude foreign citizens.

Source: OECD, based on OECD/UNESCO Institute for Statistics/Eurostat data collection on careers of doctorate holders 2010; Eurostat 2012 
21. Compared to the other countries, Germany and Sweden, while both exhibiting a relatively high share of employees ( $81 \%$ and $82 \%$, respectively), have a higher proportion of their doctoral population which is self-employed. Else, all economies for which data are available exhibit a high share of employees among its doctoral population. Indeed, this labour force group accounts for $90 \%$ or more of total doctorate holders in 19 out of 21 economies. ${ }^{5}$

22. The share of part-time contracts ranges between $1 \%$ and $9 \%$ for most economies. Exceptions are Lithuania, Latvia, Germany and Israel, for which the share of doctoral graduates with part time contracts is higher, i.e. $10 \%$ to $16 \%$. The share of doctoral graduates working part time is less than or equal to that for ISCED level $5 \& 6$ graduates for only slightly under half of the economies for which data are available. In Latvia and Lithuania, the amount of doctoral graduates with part time contracts surpasses that of tertiary graduates by 8 percentage points and 6 percentage points, respectively.

Figure 9. Percentage of doctorate holders working part time, by gender, 2009 As a percentage of employed doctorate holders

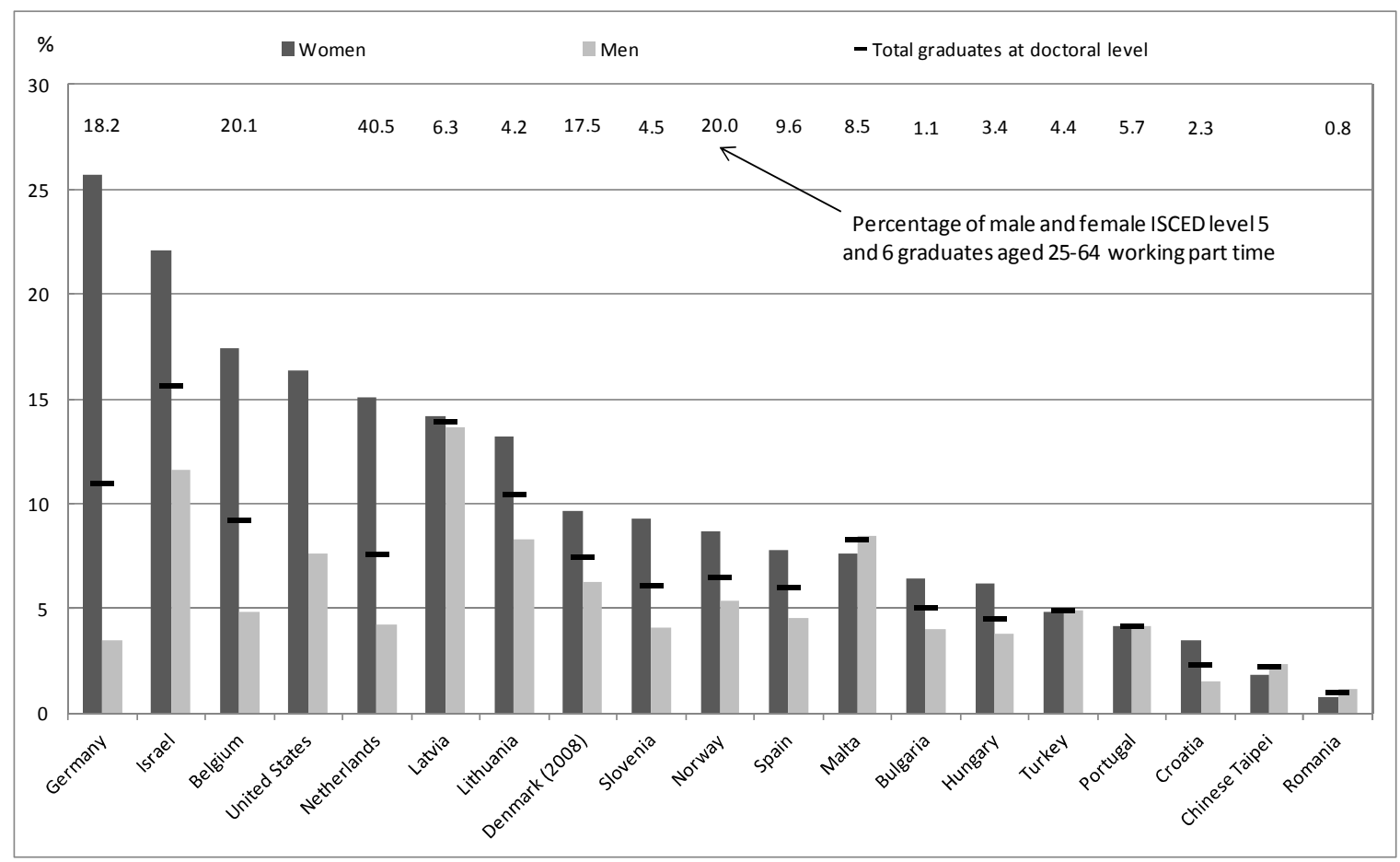

Notes:

*Data for Belgium, Germany, Hungary, the Netherlands and Spain refer to graduation years 1990 onwards.

*For the Russian Federation, data relate only to those doctoral graduates employed as researchers and teachers.

*For Slovenia, "part-time" refers to doctorate holders working less than 30 hours per week.

*For Spain, there is limited coverage of doctorate holders for the years 2007 to 2009.

*Data for Turkey exclude foreign citizens.

Source: OECD, based on OECD/UNESCO Institute for Statistics/Eurostat data collection on careers of doctorate holders 2010; Eurostat 2012.

5. Belgium, Bulgaria, Chinese Taipei, Croatia, Denmark, Finland, Hungary, Israel, Latvia, Lithuania, Malta, the Netherlands, Poland, Portugal, Russian Federation, Slovenia, Spain, and Turkey. 
23. Not surprisingly, gender dynamics reveal that the share of part time contracts is higher among women doctoral graduates in all but 5 economies: Malta, Turkey, Portugal, Chinese Taipei and Romania (Figure 9). The difference is particularly marked in Germany, Israel, Belgium, the United States, and the Netherlands. This situation to some extent differs from that for all tertiary level graduates, where the prevalence of part time employees among females exceeds that among males in all cases.

24. Over $90 \%$ of doctorate holders are employed as either professionals or managers (Figure 10). Yet, $\mathrm{CDH}$ data suggests that roughly $6 \%$ of doctorate holders in Norway, $8 \%$ in the Netherlands and between 3\% and 4\% in Latvia and Lithuania are employed in other occupations, indicating possible over qualification of some doctorate holders in these economies. In the Netherlands and Lithuania doctorate holders employed in occupations other than managers and professionals tend to have degrees in Humanities and/or Social sciences while those in Norway and Latvia tend to have degrees in Engineering and technology. Economies that report a high share of doctorate holders in unspecified occupations include Poland (11\%) and Belgium (9\%).

Figure 10. Employed doctorate holders, by main occupation, 2009 As a percentage of employed doctorate holders

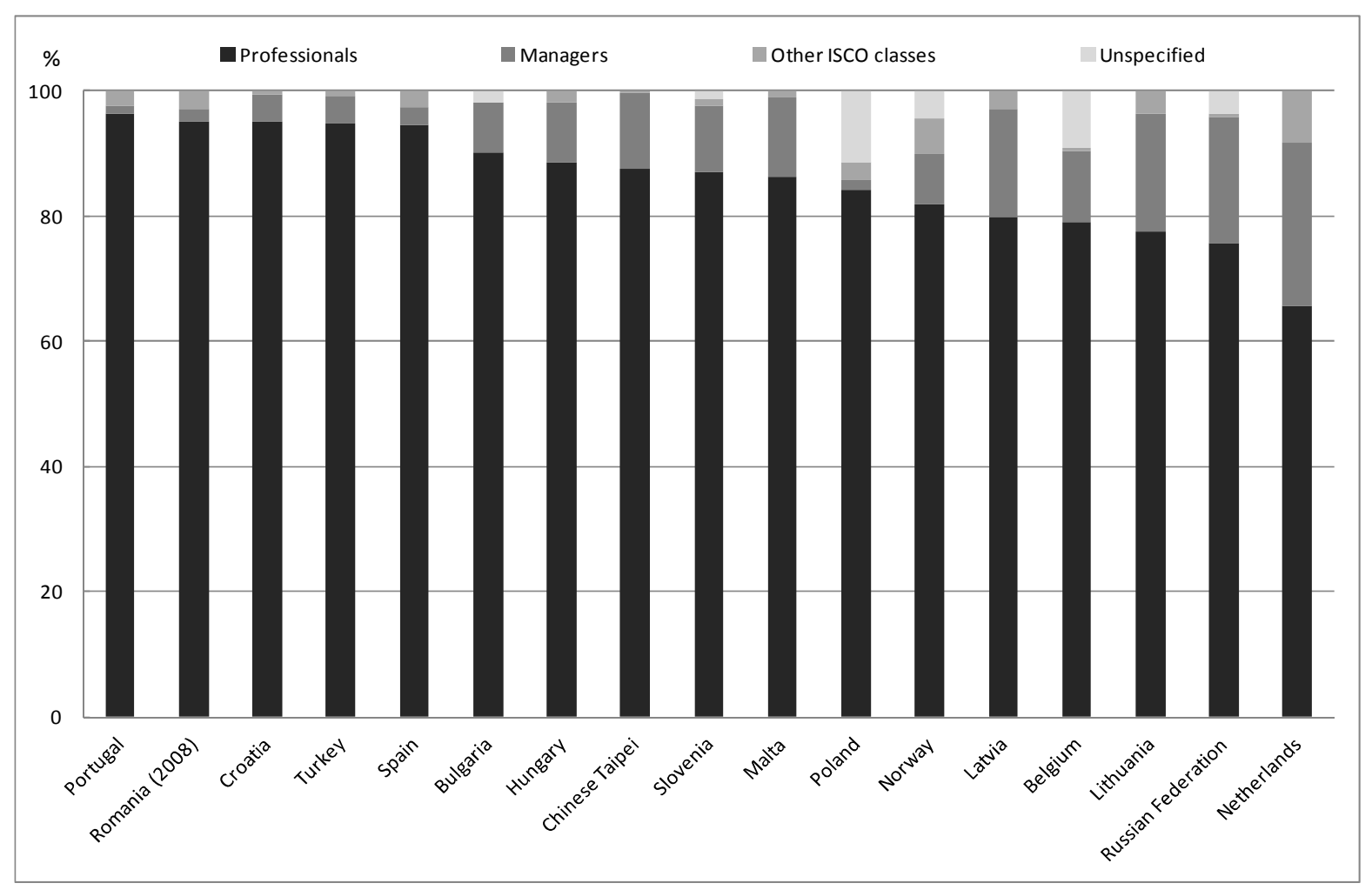

Notes:

*Data for Belgium, Hungary, the Netherlands and Spain refer to graduation years 1990 onwards.

*For the Russian Federation, data relate only to those doctoral graduates employed as researchers and teachers.

*For Spain, there is limited coverage of doctorate holders for the years 2007 to 2009.

*Data for Turkey exclude foreign citizens.

Source: OECD, based on OECD/UNESCO Institute for Statistics/Eurostat data collection on careers of doctorate holders 2010. 
25. What are the major sectors of employment for doctoral graduates? $\mathrm{CDH}$ data indicate that the education sector is indeed the main institutional sector ${ }^{6}$ of employment for individuals with a doctorate degree, accounting for a rather variable proportion of doctorates, from around one-third of the total in the Netherlands, Denmark and Belgium, to nearly four-fifths in Poland and Portugal. Government and business sectors alternate as the second most important destination. In Belgium, Denmark and the United States, at least one out of three employed doctorate holders works in the business sector (Figure 11).

Figure 11. Doctorate holders, by sector of employment, 2009 As a percentage of employed doctorate holders

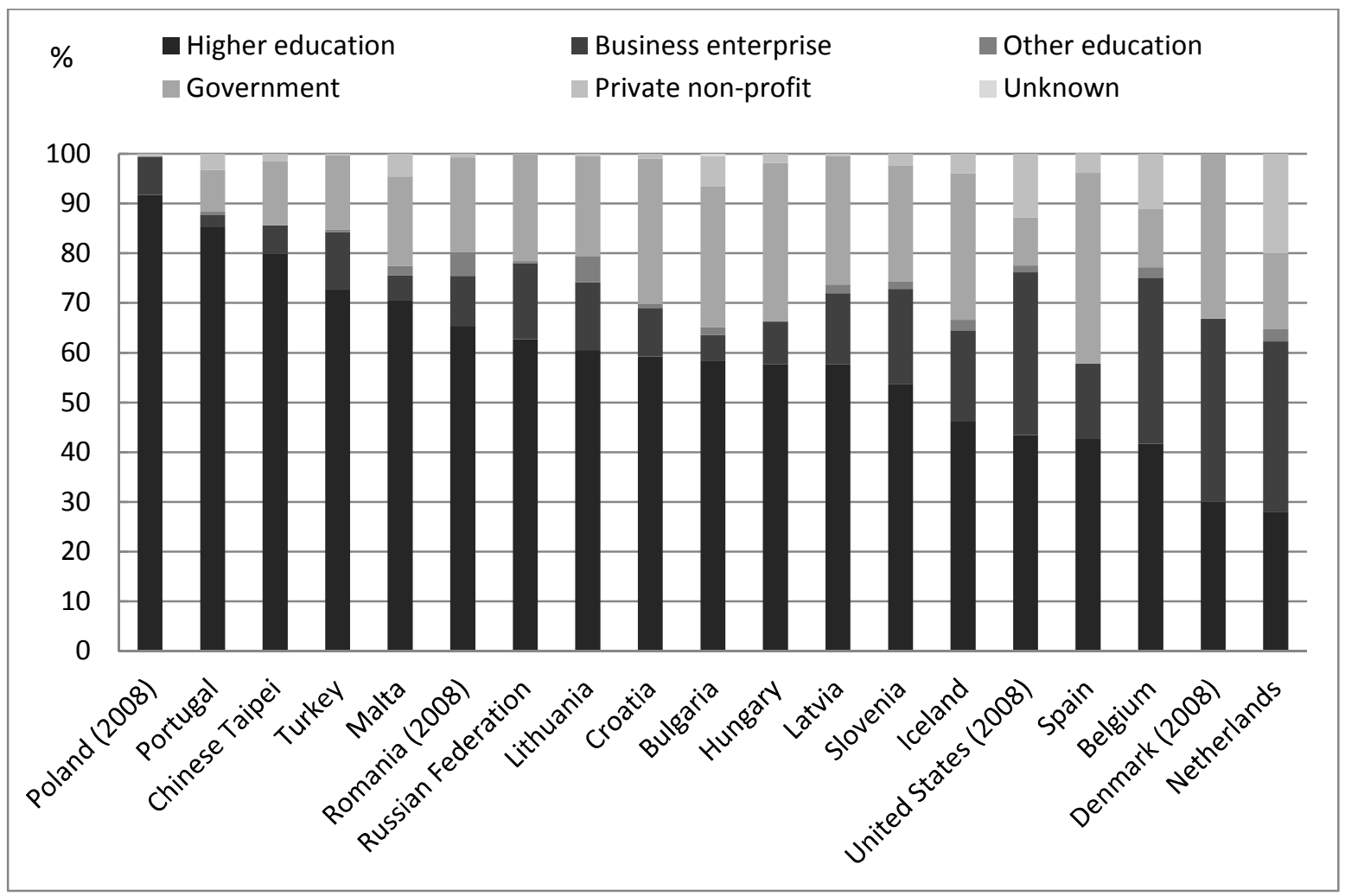

Notes:

*Data for Belgium, Hungary, the Netherlands and Spain refer to graduation years 1990 onwards.

*For the Russian Federation, data relate only to those doctoral graduates employed as researchers and teachers.

*For Spain, there is limited coverage of doctorate holders for the years 2007 to 2009.

*Data for Turkey exclude foreign citizens.

*Data for the United States exclude doctorate holders who received degree abroad and who received a doctorate in humanities.

Source: OECD, based on OECD/UNESCO Institute for Statistics/Eurostat data collection on careers of doctorate holders 2010.

\section{Earnings of doctorate holders}

26. The level of earnings may be determinant in the choice of a particular career. Earning differentials between sectors of employment and between countries may also influence preferences for specific occupations or locations. Earnings of doctorate holders have been collected for 18 countries as part of the $\mathrm{CDH}$ project. Further down this paper, earning differentials are analysed according to several variables, but the first striking result emerging from the levels of median gross annual earnings converted in purchasing power parities (PPPs) is the wide variation existing across countries, ranging from 18306

6. Based on the sectoral classification for R\&D performing units in the OECD Frascati Manual (OECD, 2002), which includes Higher Education, Business Enterprise, Government and Other Private non-Profit. 
US dollar PPPs in the Russian Federation to 93000 in the United States, i.e. a factor of 1 to $5^{7}$. Doctorate holders are the lowest paid in Central and Eastern European countries (with the exception of Slovenia), while the highest median gross annual earnings are found in the United States and the Netherlands (Figure 12). Although the target population was not the same, a large variation in the remuneration of researchers across countries at the global level, was also noted in a study conducted by the European Commission in 2007 (EC, 2007).

Figure 12. Median gross annual earnings of doctorate holders, 2009 USD PPPs

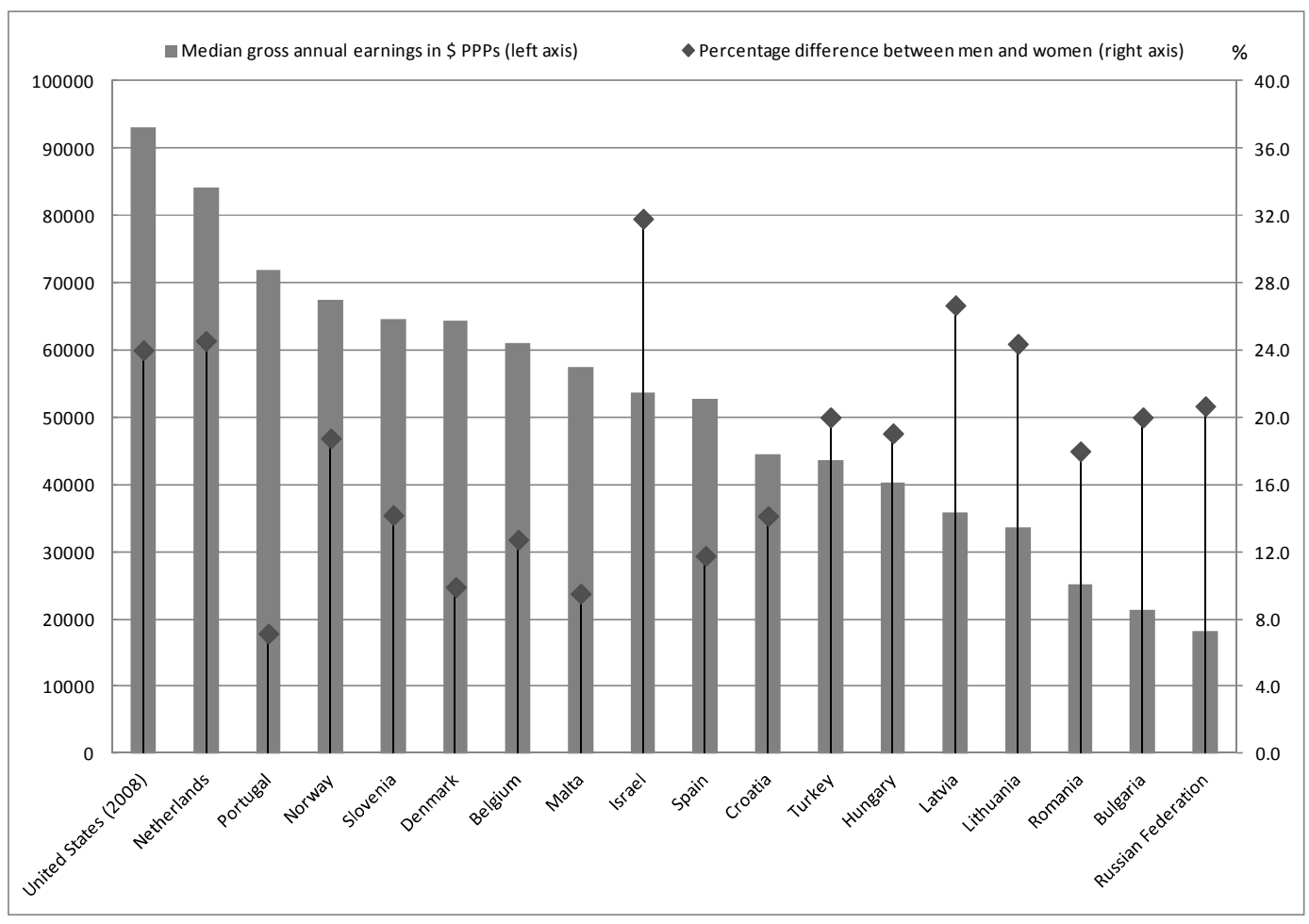

Notes:

*Data for Hungary, the Netherlands and Spain refer to graduation years 1990 onwards.

*For the Russian Federation, data relate only to those doctoral graduates employed as researchers and teachers.

${ }^{*}$ For Spain, there is limited coverage of doctorate holders for the years 2007 to 2009.

*Data for Turkey exclude foreign citizens.

* Data for the United States exclude doctorate holders who received degree abroad and who received a doctorate in humanities

Source: OECD, based on OECD/UNESCO Institute for Statistics/Eurostat data collection on careers of doctorate holders 2010.

27. Figure 12 also highlights differences in male and female median gross annual earnings. The percentage difference is calculated as the difference between male and female median gross annual earnings, divided by male median gross annual earnings. This figure brings to the forefront that male doctoral graduates have higher earnings than their female counterparts for all economies for which data are available. However, this indicator does not allow comparing earnings at the same position level. Therefore, in addition to possible inequalities, the differences may be explained by different factors such as a younger average age of women and consequently a lower seniority, as well as the fact that women are more frequently working part-time. For certain economies, such as Latvia, the Netherlands, Lithuania and the United States the difference is close to or above $25 \%$ at the total economy level.

7. The relative low level of median gross annual earnings in the Russian Federation may be partly explained by an under coverage of doctorate holders working in the business enterprise sector. 
28. At the sectoral level, the difference between male and female median gross annual earnings is most marked in the business enterprise and government sectors, as shown in figure 13. Indeed, the differential exceeds $20 \%$ for the Netherlands Turkey, Bulgaria, Hungary, Slovenia, Malta and Portugal in the business enterprise sector, and Latvia, the Netherlands, Lithuania, Russian Federation and Malta in the government sector.

Figure 13. Difference in median gross annual earnings of male and female doctorate holders, 2009 As a percentage of gross annual earnings of male doctorate holders

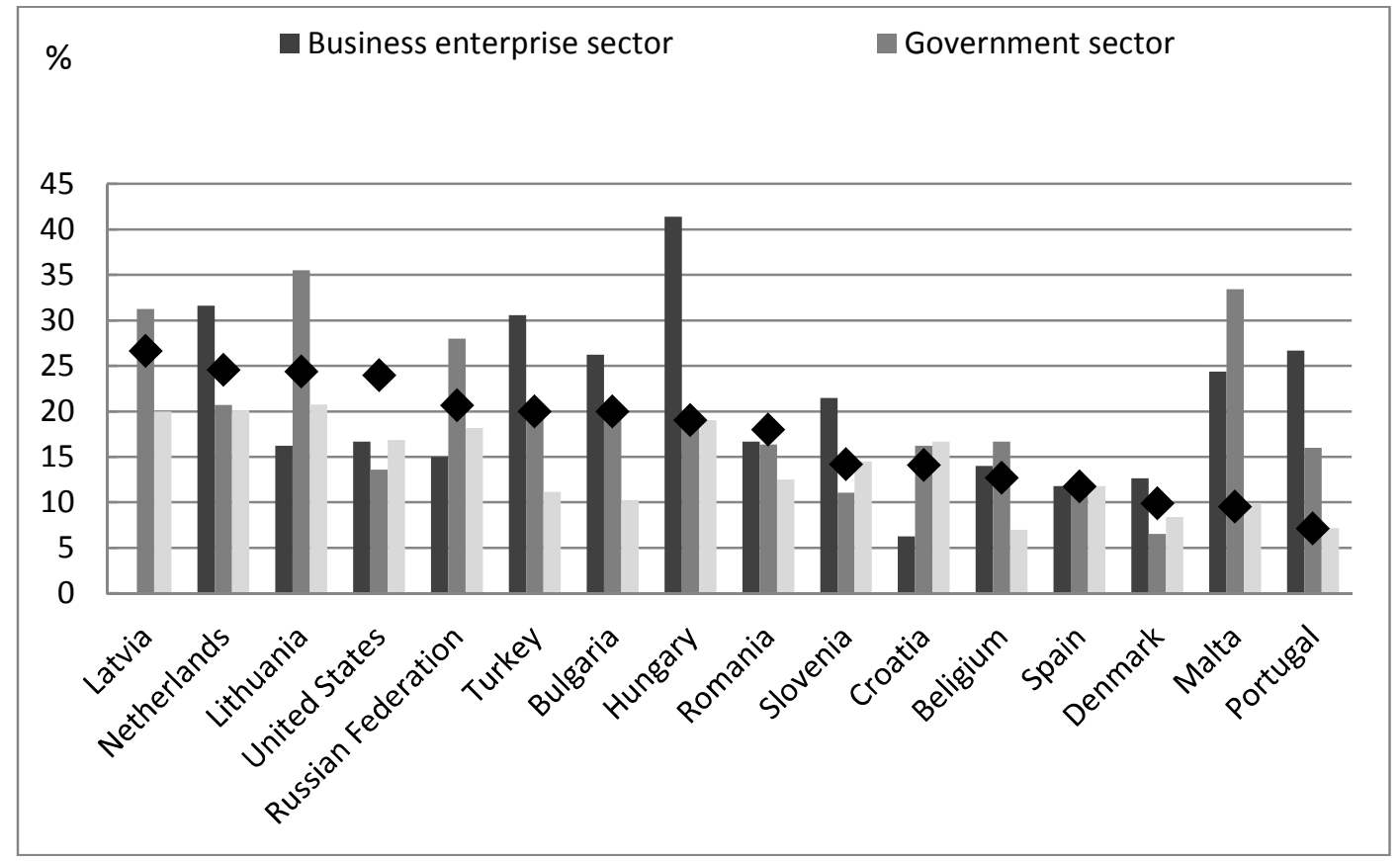

Notes:

*All sectors include the business enterprise, government, higher education, other education and private non-profit sectors.

*Data for Hungary, the Netherlands and Spain refer to graduation years 1990 onwards.

*For the Russian Federation, data relate only to those doctoral graduates employed as researchers and teachers.

${ }^{*}$ For Spain, there is limited coverage of doctorate holders for the years 2007 to 2009.

*Data for Turkey exclude foreign citizens.

*Data for the United States exclude doctorate holders who received degree abroad and who received a doctorate in humanities.

Source: OECD, based on OECD/UNESCO Institute for Statistics/Eurostat data collection on careers of doctorate holders 2010.

\section{Doctorate holders' perception of their professional positions}

29. How do jobs of doctorate holders relate to their degree? This question is fundamental given the time investment and heavy research training involved in obtaining a doctoral degree.This section relies upon qualitative $\mathrm{CDH}$ data on perception of employed doctorate holders to address this issue.

30. The share of doctorates employed in jobs that are related to their doctoral degree varies greatly across economies (figure 14). Whereas CDH data for Portugal, the Russian Federation, Croatia, Romania, Bulgaria, Hungary and Turkey indicate that over $95 \%$ of doctorate holders are employed in jobs that are related or partly related to their degree, this is not the case for Belgium, Spain, the Netherlands and Latvia. Indeed, for this latter group of economies, between $15 \%$ and $30 \%$ of doctoral graduates perceive that their job is not related to their field of specialisation. Individuals, when progressing into their career, may shift towards a broader range of topics, functions and to administrative or managerial tasks. Indeed, the data show that the share of doctorates employed in jobs that are related to their degrees is higher for the younger cohorts in nearly half of the economies shown in Figure 14. 
Figure 14. Doctorate holders whose jobs are not related to their field of study over career path, 2009 As a percentage of employed doctorate holders in all relation criteria

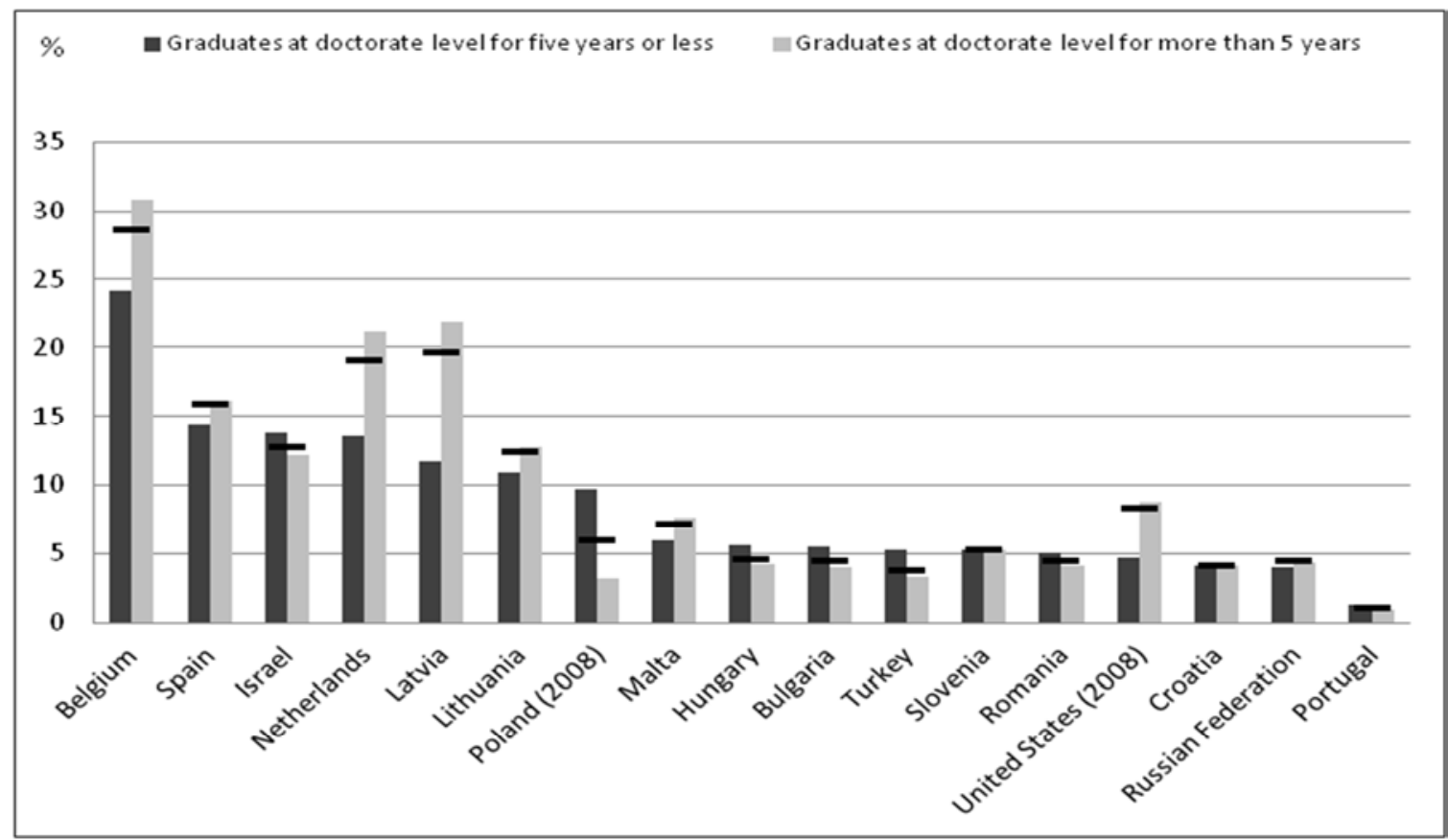

Notes:

*Data for Belgium, Hungary, the Netherlands and Spain refer to graduation years 1990 onwards.

*For Belgium, Malta and the Russian Federation, data for the 65-69 age class include doctorate holders aged 70 years and above.

${ }^{*}$ For the Russian Federation, data relate only to those doctoral graduates employed as researchers and teachers.

*For Spain, there is limited coverage of doctorate holders for the years 2007 to 2009.

*Data for Turkey exclude foreign citizens.

*For the United States, data exclude doctorate holders who received their degree abroad and who received a doctorate in humanities.

Source: OECD, based on OECD/UNESCO Institute for Statistics/Eurostat data collection on careers of doctorate holders 2010.

\section{Career as a researcher and attractiveness of research careers}

\section{Doctorate holders working as researchers}

31. The structure of labour markets and the organisation of research systems have undergone significant changes which have contributed to traditional linear research career paths giving way to a more diverse range of career experiences. In the run-up to the economic and financial crisis, "job hopping" among the highly skilled had become more common and tenured positions in the academic sector declined in importance relative to temporary ones. With the high growth in new doctoral awards, some observers have wondered whether innovation systems are mature enough to create research positions that fully utilise the skills of the doctorate population. Considering these questions requires a better understanding of differences between doctorates employed as researchers and those who are not, evaluating for example to what extent occupations are related to the doctoral studies, satisfaction, pay and their evolution in the short to longer term. Across countries for which data are available, at least $50 \%$ of doctorate holders are working in research. In Portugal and Poland, more than $80 \%$ of doctorate holders work as researchers, whereas the shares are lower (close to 60\%) in Belgium, the Netherlands and the United States (Figure 15).

32. Doctorate holders in the natural sciences and engineering are the most frequently employed as researchers, except in Portugal and Poland where there are no obvious differences across fields and the share of researchers is high. By contrast, large deviations across fields of study exist in countries where a non-research career is more common. 
Figure 4. Figure 15. Percentage of doctorate holders working as researchers, 2009

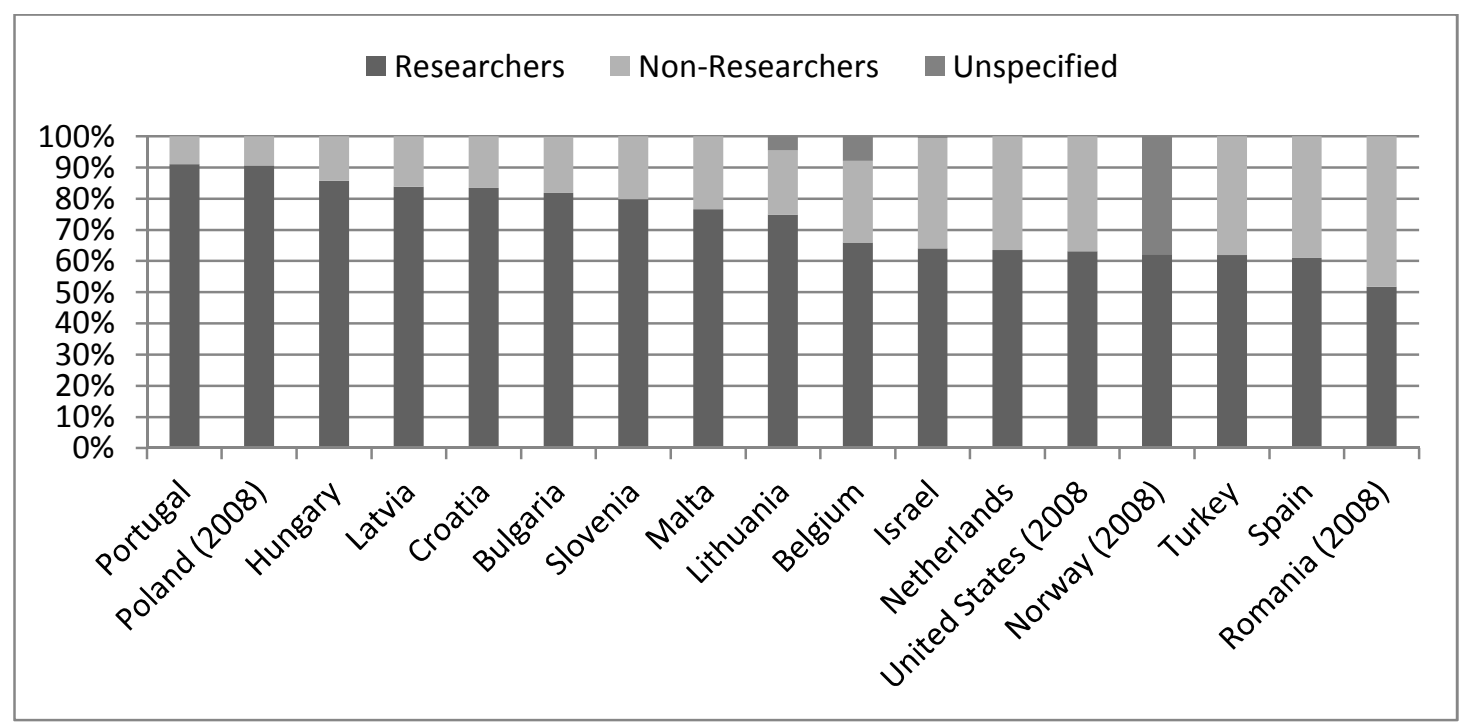

Notes:

*Data for Belgium, Hungary, the Netherlands and Spain refer to graduation years 1990 onwards.

*For Belgium, Malta and the Russian Federation, data for the 65-69 age class include doctorate holders aged 70 years and above.

*For Norway, data for researchers in the business sector only cover R\&D institutes and not enterprises.

*For Spain, there is limited coverage of doctorate holders for the years 2007 to 2009.

*Data for Turkey exclude foreign citizens.

Source: OECD, based on OECD/UNESCO Institute for Statistics/Eurostat data collection on careers of doctorate holders 2010.

Figure 16. Percentage of doctorate holders working as researchers by field of study, 2009

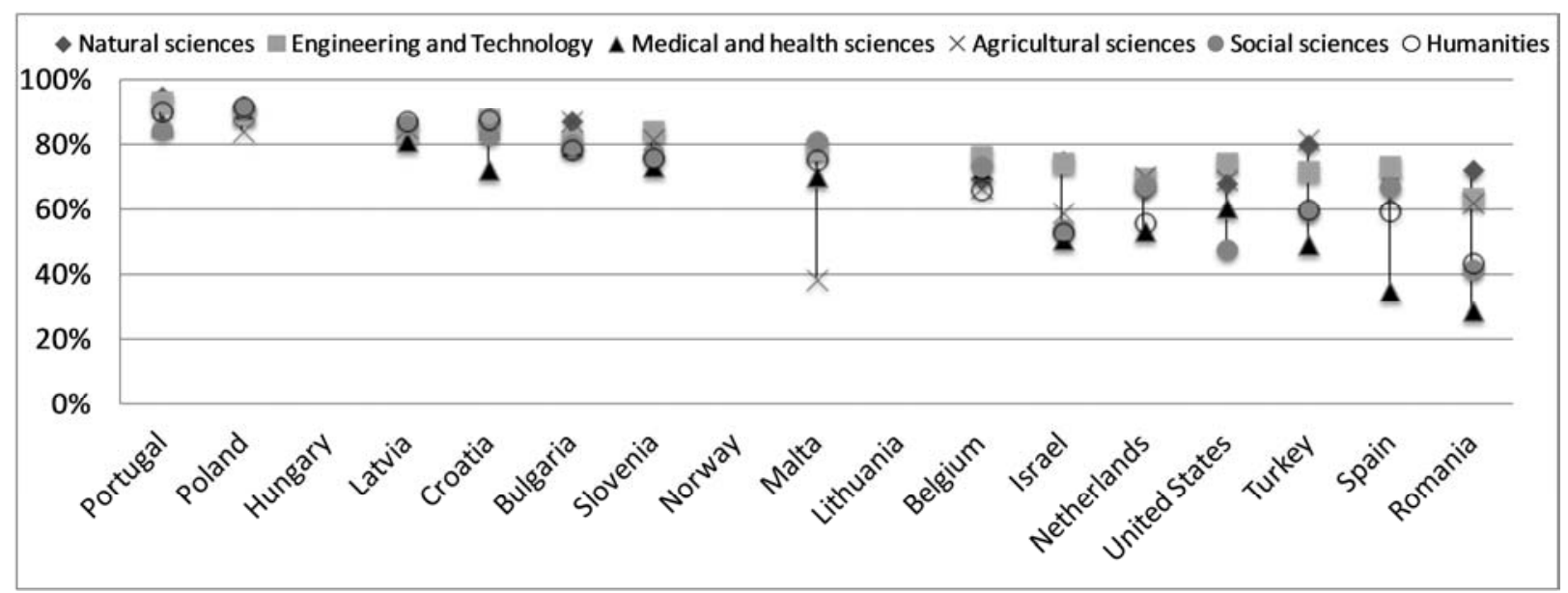

Notes:

*Data for Belgium, Hungary, the Netherlands and Spain refer to graduation years 1990 onwards.

*For Belgium, Malta and the Russian Federation, data for the 65-69 age class include doctorate holders aged 70 years and above.

*For Norway, data for researchers in the business sector only cover R\&D institutes and not enterprises.

${ }^{*}$ For Spain, there is limited coverage of doctorate holders for the years 2007 to 2009.

*Data for Turkey exclude foreign citizens.

*Data for the United States exclude doctorate holders who received degree abroad and who received a doctorate in humanities.

Source: OECD, based on OECD/UNESCO Institute for Statistics/Eurostat data collection on careers of doctorate holders 2010.

33. How is advanced research training related to the demand for researchers? Figure 17 shows that the main sector of employment for doctorate holders working as researchers is the higher education in most countries. In Belgium, the United States and the Netherlands, the business enterprise sector also employs a large share of doctorate holders as researchers. Since doctorate holders are traditionally keen to pursue an 
academic research career, such a large share of doctorate holders employed as researchers in the business enterprise sector may reflect a greater demand for highly skilled personnel outside of academia and/or less available opportunities in the higher education sector. Since the business enterprise sector has been the main $R \& D$ performer in the OECD area in terms of the number of research personnel and R\&D expenditure (OECD 2011b), how well countries utilise the skills and knowledge of advanced degree holders in this sector may have some impacts on the transfer of new academic knowledge to the private sector and on enhancing university-industry ties for further innovation.

Figure 17. Sector of employment of doctorate holders working as researchers, 2009

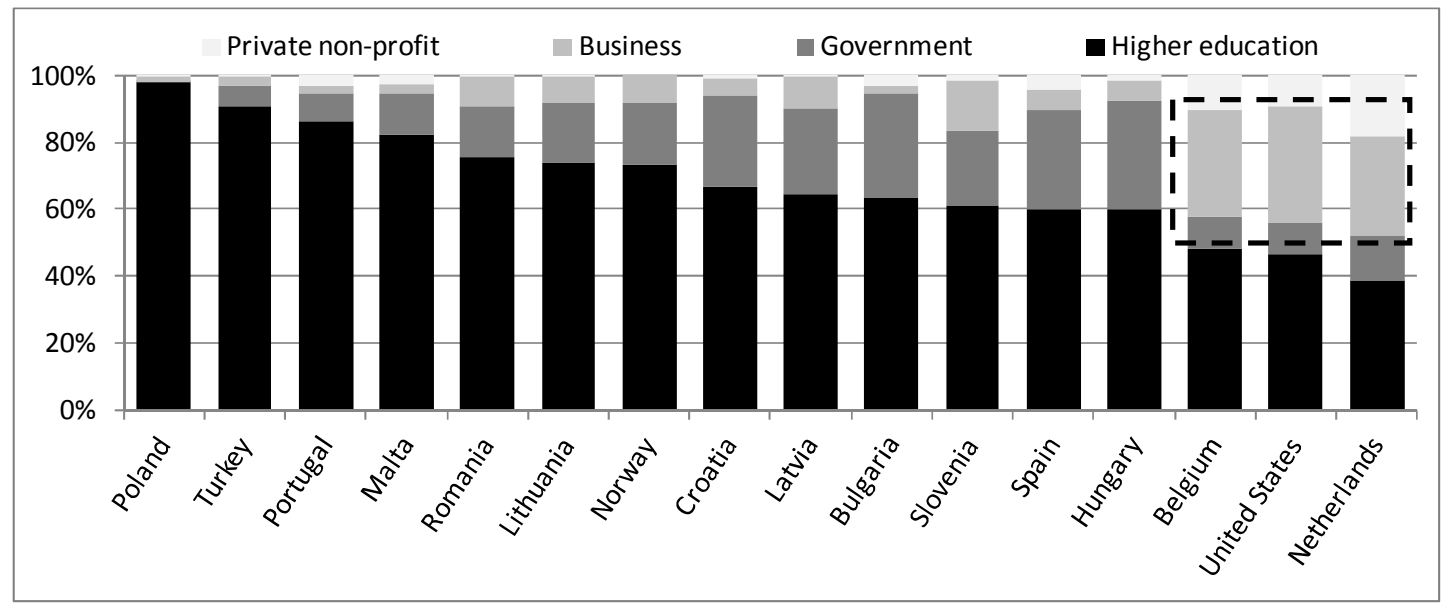

Notes;

*Data for Belgium, Hungary, the Netherlands and Spain refer to graduation years 1990 onwards.

*For Spain, there is limited coverage of doctorate holders for the years 2007 to 2009.

*Data for Turkey exclude foreign citizens.

Source: OECD, based on OECD/UNESCO Institute for Statistics/Eurostat data collection on careers of doctorate holders 2010.

34. The previous $\mathrm{CDH}$ data collection already found that the business enterprise sector primarily employs doctorate holders who studied natural sciences or engineering. (Auriol, 2010) This is also the case for doctorate holders working as researchers. Figure 18 shows that the business enterprise sector also engage natural scientists and engineers as researchers, especially in countries such as Belgium, the Netherlands and the United States. In particular, approximately half of doctoral graduates in engineering and technology working as researchers are employed in the business enterprise sector in these countries. These countries are, to some extent, also able to empower the business enterprise sector with the supply of doctoral graduates specialised in social sciences and humanities; however, the supply from these two fields remain around $10 \%$ or less and quite low as compared to other graduates in S\&E fields (Figure 19). It is also interesting to see that a comparatively high percentage of doctoral graduates are employed as researchers in the private non-profit sector in these countries. While natural scientists and engineers are generally expected to be in higher demand in the business enterprise sector, the supply of these two types of specialists to the business enterprise sector is quite minimal in countries like Poland, Portugal and Turkey. 
Figure 18. Employment sector of doctorate holders with doctoral education in S\&E fields working as researchers, 2009

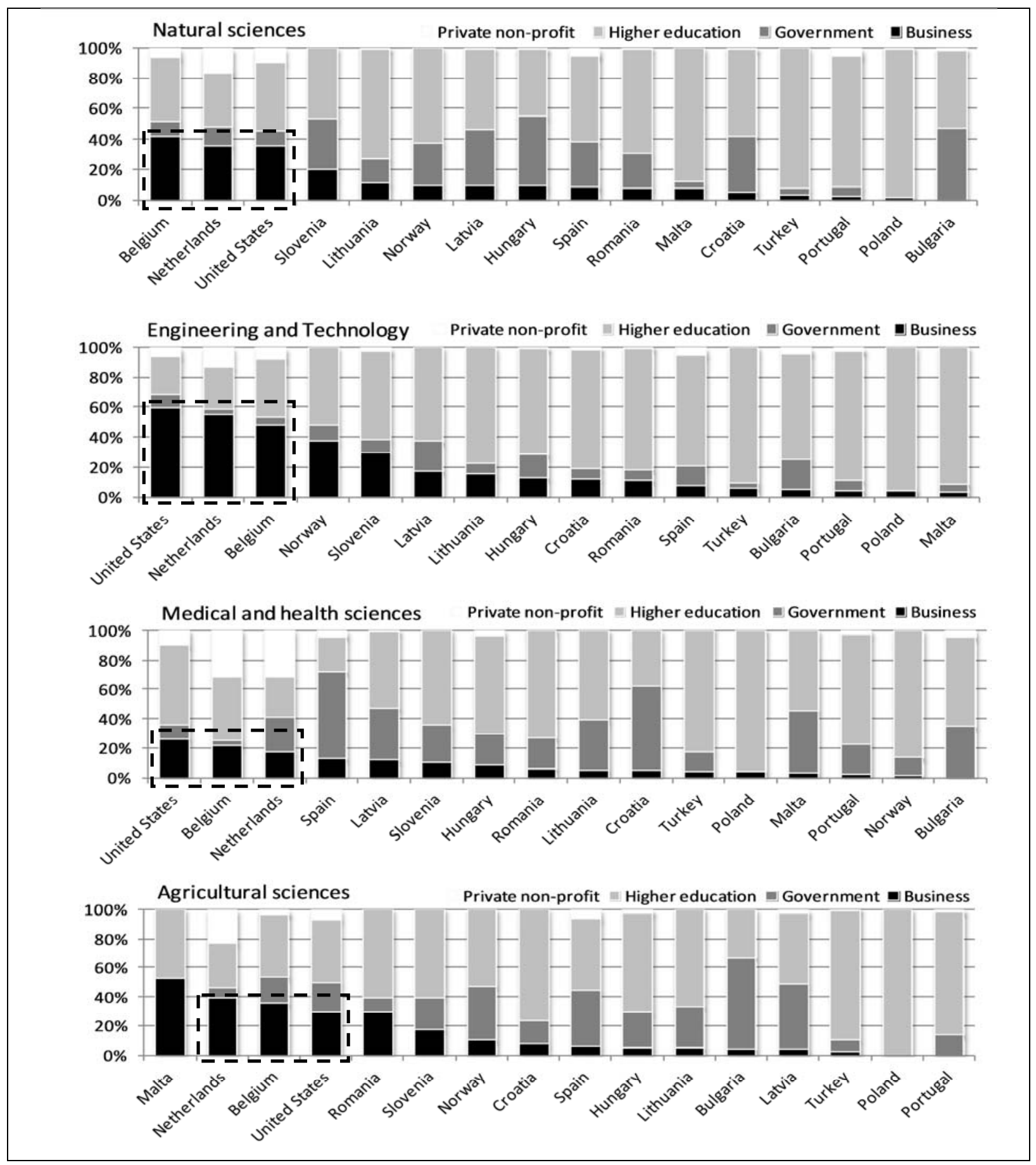

Notes:

*Data for Belgium, Hungary, the Netherlands and Spain refer to graduation years 1990 onwards.

*For Belgium, Malta and the Russian Federation, data for the 65-69 age class include doctorate holders aged 70 years and above.

*For Norway, data for researchers in the business sector only cover R\&D institutes and not enterprises.

*For Spain, there is limited coverage of doctorate holders for the years 2007 to 2009.

*Data for Turkey exclude foreign citizens.

*Data for the United States exclude doctorate holders who received degree abroad and who received a doctorate in humanities. Source: OECD, based on OECD/UNESCO Institute for Statistics/Eurostat data collection on careers of doctorate holders 2010. 
Figure 19. Employment sector of doctorate holders with doctoral education in Social sciences and Humanities working as researchers, 2009

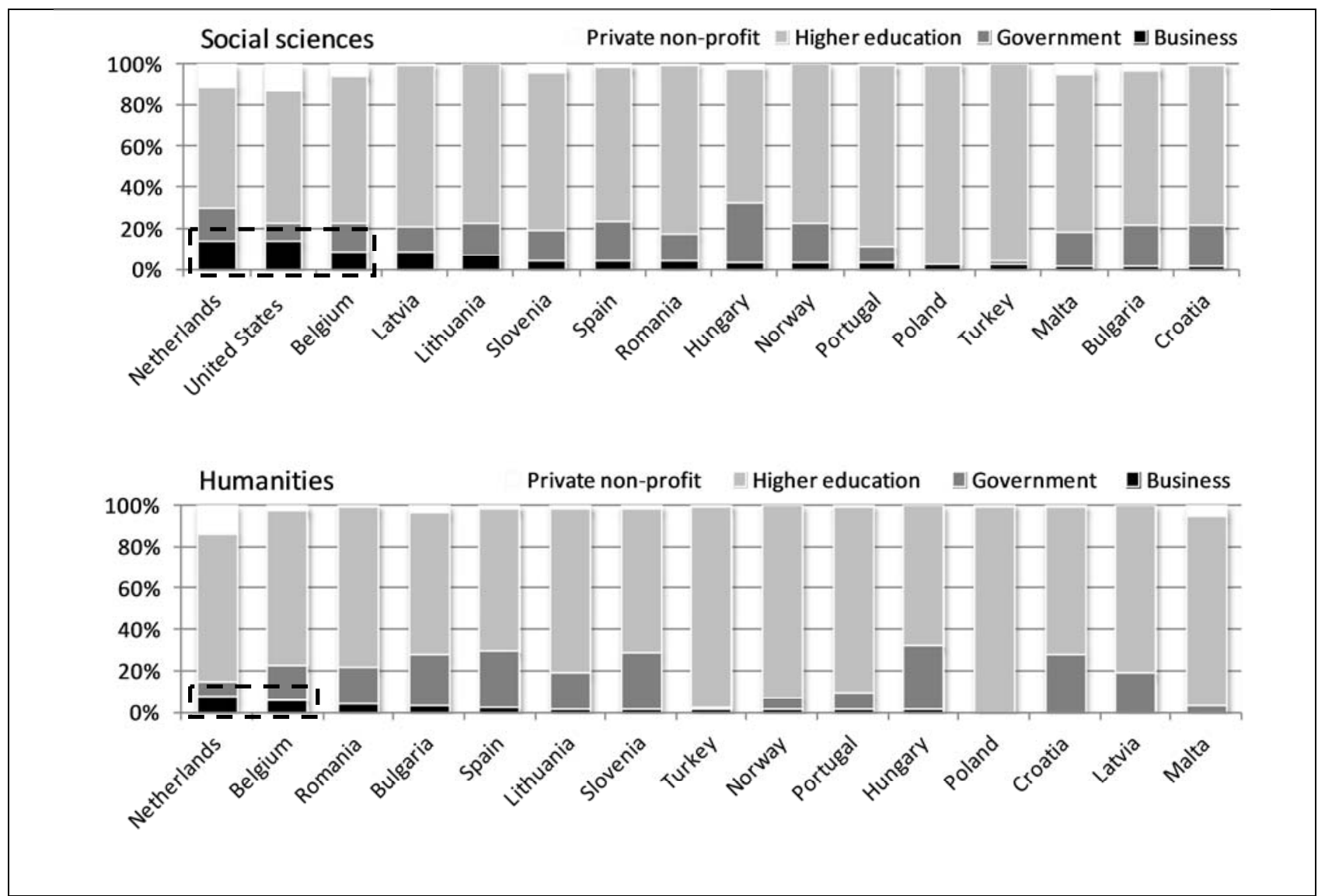

Notes:

${ }^{*}$ Data for Belgium, Hungary, the Netherlands and Spain refer to graduation years 1990 onwards.

${ }^{*}$ For Belgium, Malta and the Russian Federation, data for the 65-69 age class include doctorate holders aged 70 years and above.

${ }^{*}$ For Norway, data for researchers in the business sector only cover R\&D institutes and not enterprises.

*For Spain, there is limited coverage of doctorate holders for the years 2007 to 2009.

${ }^{*}$ Data for Turkey exclude foreign citizens.

*Data for the United States exclude doctorate holders who received degree abroad and who received a doctorate in humanities.

Source: OECD, based on OECD/UNESCO Institute for Statistics/Eurostat data collection on careers of doctorate holders 2010.

\section{Attractiveness of research careers}

35. It is of common interest in both OECD member and non-member countries to attract the brightest and most innovative researchers by promoting research careers. In reality, some countries have been facing a declining interest for careers in science and technology among younger generations. The report by the President's Council of Advisors on Science and Technology (OSTP, 2004) in the United States identified some of the crucial factors for this declining interest being related to the lengthy training periods in early career such as the long duration for obtaining an advanced degree and the additional unstable postdoctoral training before securing a tenured position. Such situations may lead to lowering researchers' lifetime earnings expectations and finding a balance between family decisions and research career may be difficult especially for female researchers. Similar situations also exist in other OECD countries (OECD, 2008). 
36. How are careers of doctoral researchers valued on the labour market with respect to the return on investment for their long academic training? The available data show that gross annual earnings of doctorate holders employed as researchers exceed those of non-researchers in several countries (Figure 20). Among doctorate holders employed in the higher education sector, the earnings of those working as researchers exceed those of their non-researcher counterparts in all countries for which data is available.

Figure 20. Difference in median gross annual earnings of doctorate holders working as researchers and as non-researchers, 2009

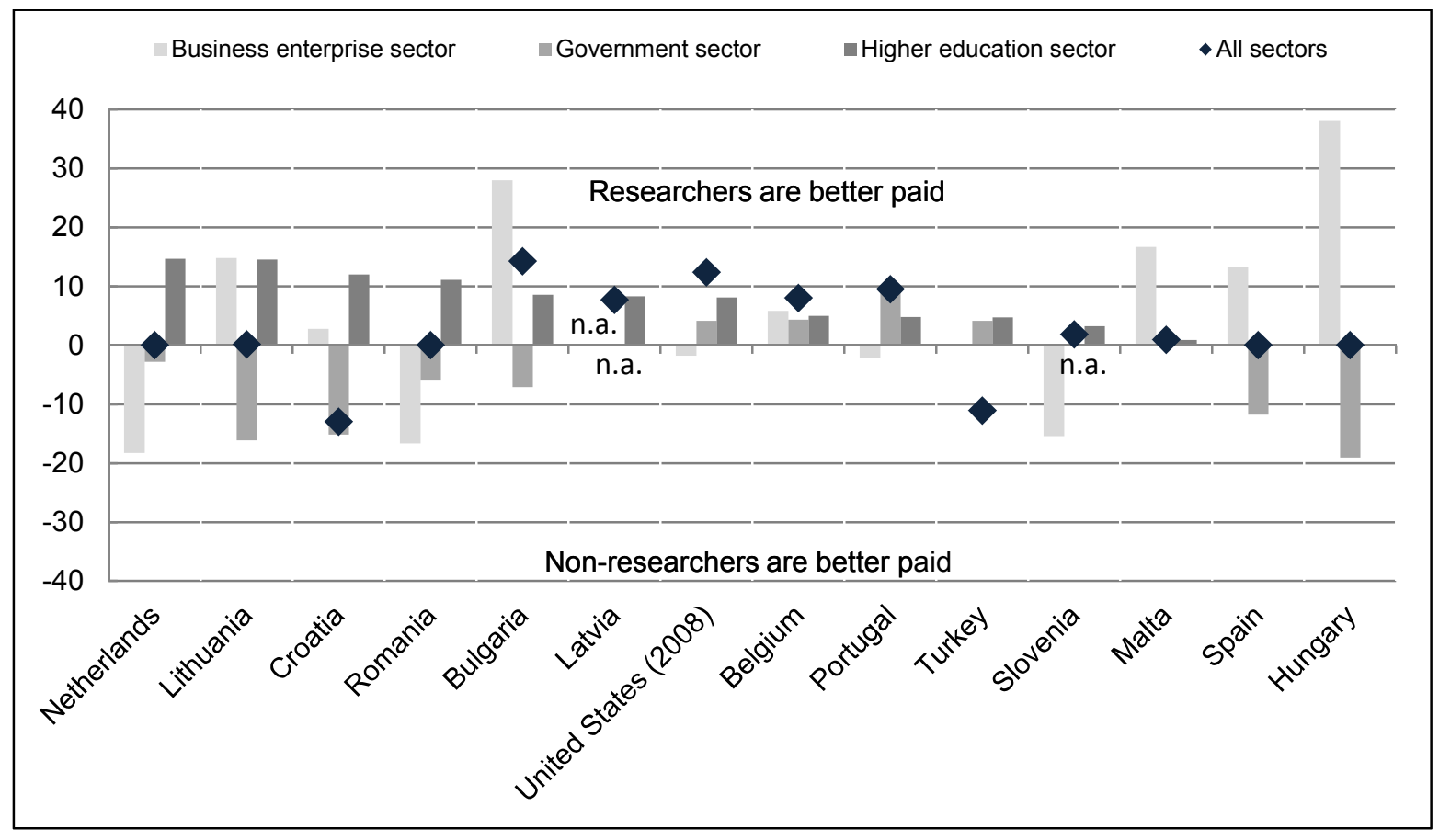

Notes:

*All sectors include the business enterprise, government, higher education, other education and private non-profit sectors.

*Data for Hungary, the Netherlands and Spain refer to graduation years 1990 onwards.

${ }^{*}$ For the Russian Federation, data relate only to those doctoral graduates employed as researchers and teachers.

*For Spain, there is limited coverage of doctorate holders for the years 2007 to 2009.

*Data for Turkey exclude foreign citizens.

*Data for the United States exclude doctorate holders who received degree abroad and who received a doctorate in humanities.

Source: OECD, based on OECD/UNESCO Institute for Statistics/Eurostat data collection on careers of doctorate holders 2010.

37. The median gross annual earnings of doctorate holders in research positions may however vary depending on the sector of employment and/or the specialized skills and knowledge acquired during doctoral studies.

38. Figure 21 shows that doctorate holders working as researchers are better paid in the business sector than in the higher education sector in most countries. As such, working as researcher in the business enterprise sector may be viewed as an attractive career option for doctorate holders; in most countries. However, a large share of doctorate holders actually favours research careers in the higher education sector over the business enterprise sector. For example, in Turkey and Hungary, the median earnings for those in the business sector are over 50\% above the overall median for all doctorate holders working as researchers, but the business sector does not seem to take advantage of doctorate holders' employment in these two countries. 
Figure 21. Percentage difference in median gross annual earnings of doctorate holders working as researchers by main sector of employment as compared to total doctorate holders working as researchers, 2009

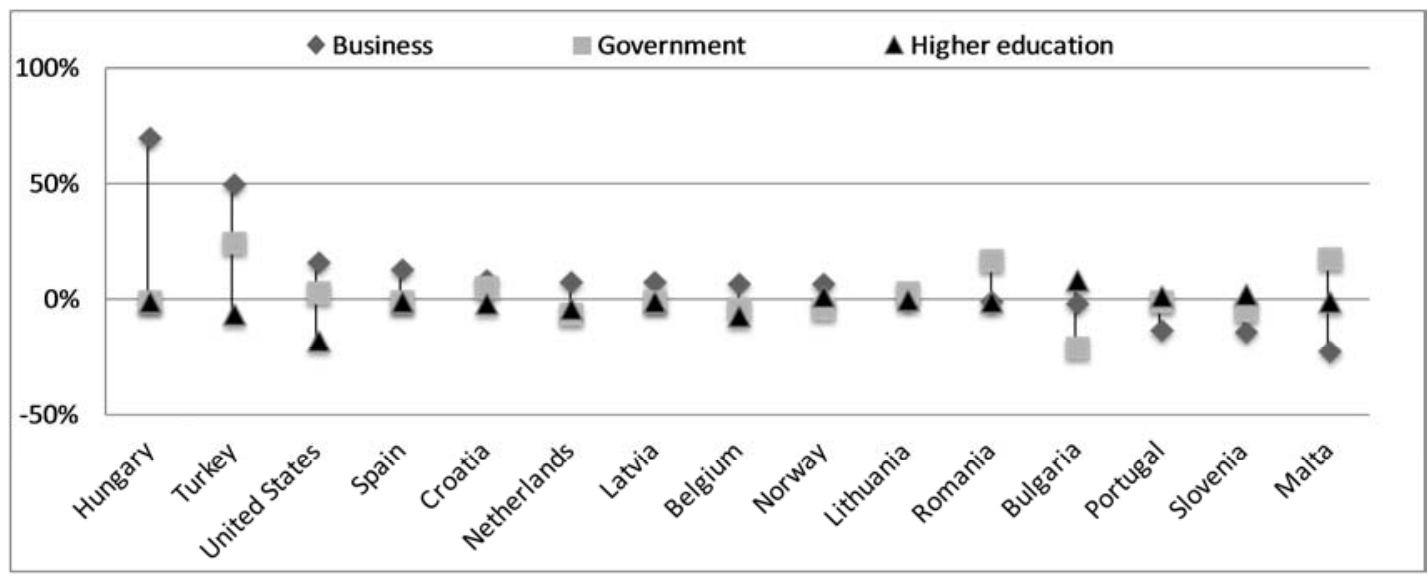

Notes:

${ }^{*}$ All sectors include the business enterprise, government, higher education, other education and private non-profit sectors.

*Data for Hungary, the Netherlands and Spain refer to graduation years 1990 onwards.

${ }^{*}$ For Spain, there is limited coverage of doctorate holders for the years 2007 to 2009.

*Data for Turkey exclude foreign citizens.

*Data for the United States exclude doctorate holders who received degree abroad and who received a doctorate in humanities.

Source: OECD, based on OECD/UNESCO Institute for Statistics/Eurostat data collection on careers of doctorate holders 2010.

39. In terms of fields of doctoral study, variations in the median gross annual earnings can be observed in several countries (see Figure 22). These variations may reflect the labour market demands for specialized skills and knowledge. In particular, the median earnings of doctoral graduates specialized in agricultural sciences and humanities are below the overall median in most countries, whereas those specialized in medical and health sciences are generally paid above the average in several countries.

Figure 22. Percentage difference in median gross annual earnings of doctorate holders working as researchers by field of doctoral study as compared to total doctorate holders working as researchers, 2009

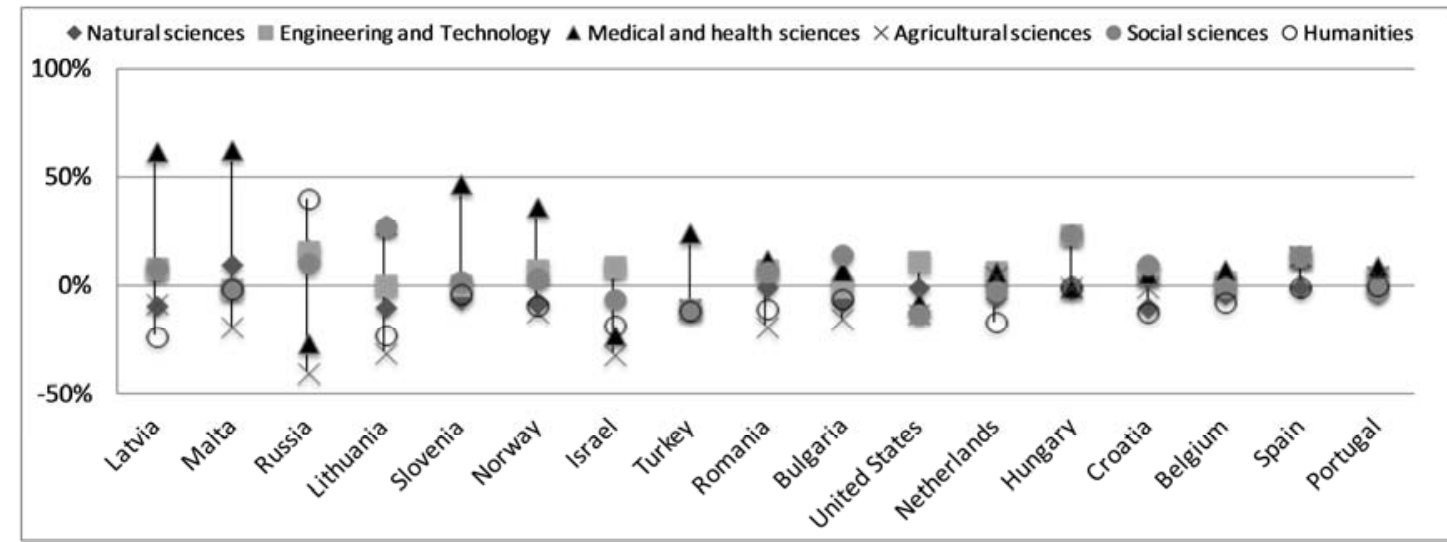

Notes:

${ }^{*}$ All sectors include the business enterprise, government, higher education, other education and private non-profit sectors.

*Data for Hungary, the Netherlands and Spain refer to graduation years 1990 onwards.

${ }^{*}$ For the Russian Federation, data relate only to those doctoral graduates employed as researchers and teachers.

*For Spain, there is limited coverage of doctorate holders for the years 2007 to 2009.

*Data for Turkey exclude foreign citizens.

*Data for the United States exclude doctorate holders who received degree abroad and who received a doctorate in humanities.

Source: OECD, based on OECD/UNESCO Institute for Statistics/Eurostat data collection on careers of doctorate holders 2010. 
40. Yet, earnings are not the only factor determining the attractiveness of research career. The CDH model questionnaire also asks doctorate holders to rate their satisfaction with their principal job in terms of (a) benefits, (b) contribution to society, (c) degree of independence, (d) intellectual challenge, (e) job security, (f) location, (g) opportunities for advancement, (h) level of responsibility, (i) salary, (j) social status, (k) working conditions, and (1) overall satisfaction. By assigning weighting values of " +2 ",", +1 ,,"1 ", and "-2" to four satisfaction levels of "very satisfied", "somewhat satisfied", "somewhat dissatisfied", and "very dissatisfied", respectively, the average satisfaction levels of doctorate holders in all countries for which data are available can be illustrated in Figure 23. It shows that doctorate holders working as researchers are overall satisfied at least as much as those working as non-researchers in most categories. In particular, satisfaction levels with two categories namely (d) intellectual challenges and (g) opportunities for advancement are remarkably higher for those working as researchers than for their counterparts. Other categories such as (c) degree of independence and (h) level of responsibility also show moderately higher satisfaction levels for those working as researchers. These elements may therefore be interpreted as making a research career attractive. Although large variations can be observed across countries, the county level data reveal similar overall patterns everywhere (Figures 24 to 26).

41. Among all categories, satisfaction levels with salary and benefits are the lowest in most countries, with no clear difference between those working as researchers and non-researchers. Since the need for introducing incentive earning schemes for excellent researchers has been recognized (Institut de France, 2008), improving satisfaction levels of researchers with salary and benefits as much as those of other categories may contribute to raising the attractiveness of research career.

Figure 23. Average satisfaction levels of doctorate holders with principal job across countries, 2009

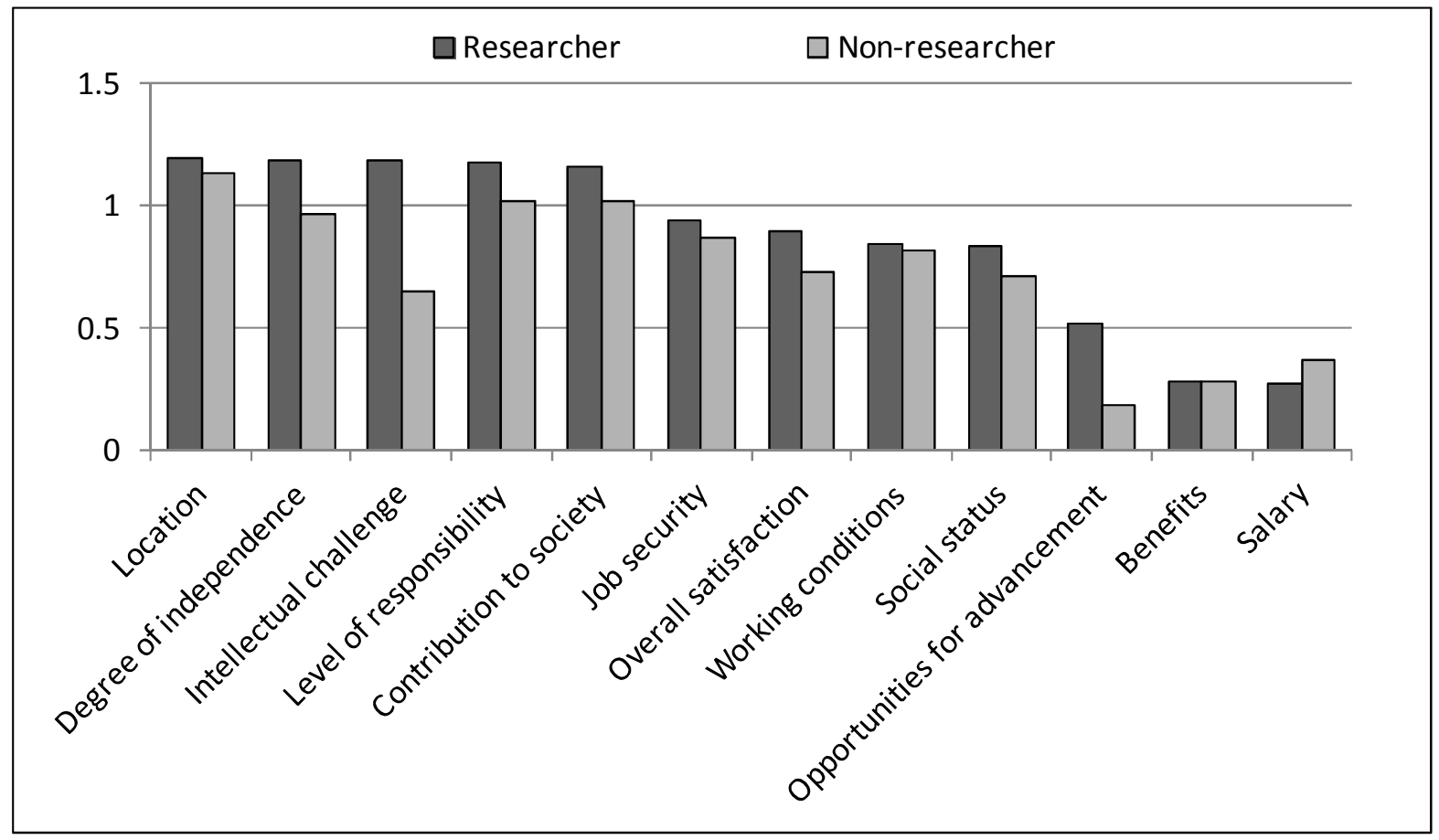

Note: The average satisfaction levels of doctorate holders are calculated by assigning values of "+2","+1","-1" and "-2" to four satisfaction levels of "very satisfied", "somewhat satisfied", "somewhat dissatisfied" and "very dissatisfied", respectively, Upper and lower ends of error bars correspond to the maximum and minimum satisfaction levels among all countries for which data are availabe.

Source: OECD, based on OECD/UNESCO Institute for Statistics/Eurostat data collection on careers of doctorate holders 2010. 
42. The above results were studied for the research career as a whole. However, since policy implications surrounding the career advancement in research are quite different depending on career stages, more careful investigations are necessary. One of the frequently asked questions is how long it takes to get a stable research position after doctoral training. This cannot be exactly answered with the present $\mathrm{CDH}$ data. Although satisfaction with job security is found to be high for doctorate holders in research and almost similar to those working as non-researchers (Figure 25), one may also expect that young researchers in early career may perceive the situation differently. The same holds true for young female researchers, at the time when some of the major life events like marriage and child care coincide with their career transition from the post-doctoral training phase to the independent researcher stages (see Box 2 as an example).

43. Under the KNOWINNO-CDH micro data work, additional tabulations and analyses will shed some light and provide a clearer understanding on the career advancement in research and also the early career stage of doctoral graduates by integrating the results of early destination surveys existing in some large non covered countries. 
Figure 24. Satisfaction levels of doctorate holders with principal job by selected criteria I, 2009

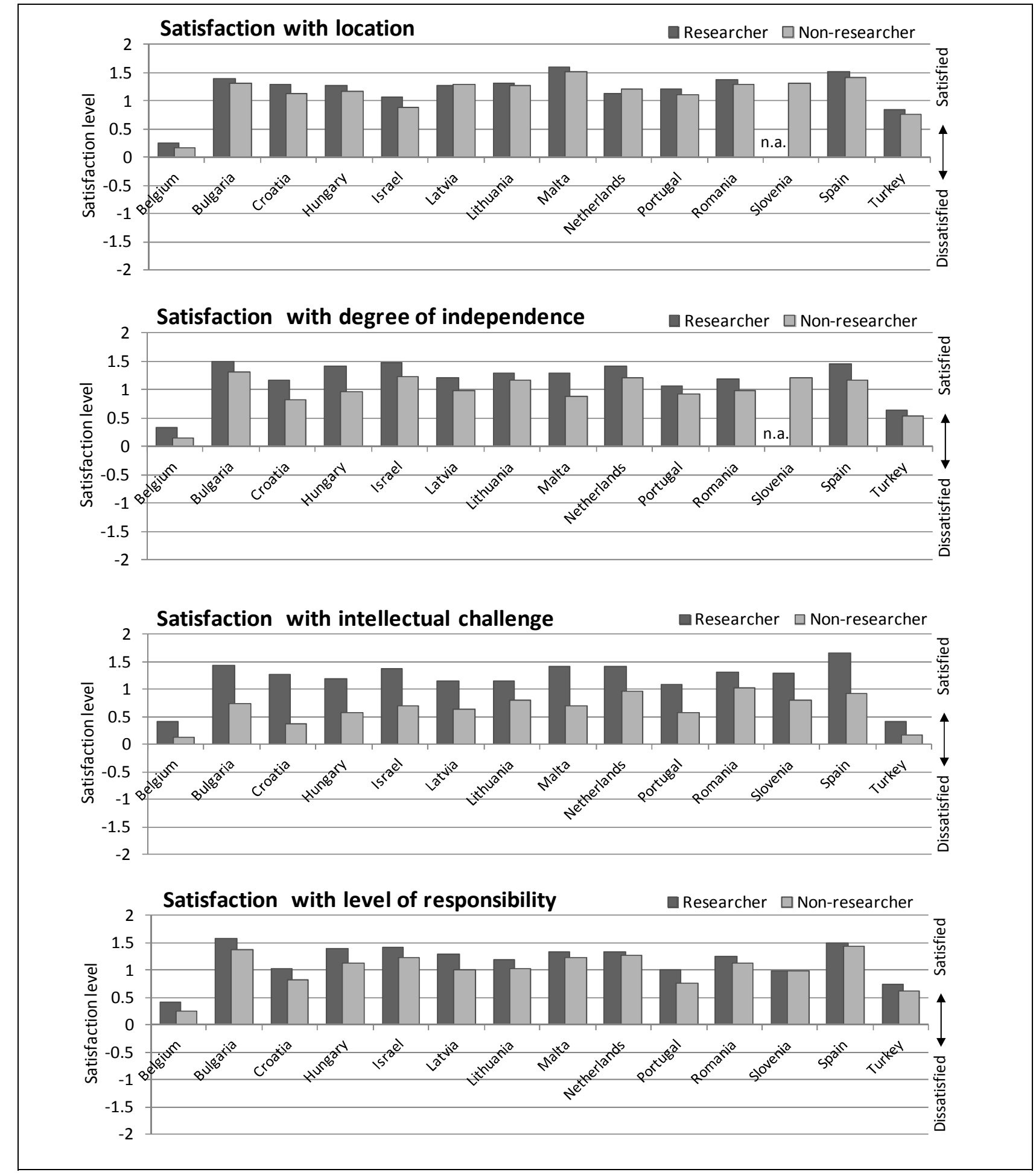

Notes:

* Satisfaction levels of doctorate holders are calculated by assigning values of "+2","+1","-1", and "-2" to four satisfaction levels of "very satisfied", "somewhat satisfied", "somewhat dissatisfied", and "very dissatisfied", respectively.

*Data for Belgium, Hungary, the Netherlands and Spain refer to graduation years 1990 onwards.

*For Spain, there is limited coverage of doctorate holders for the years 2007 to 2009.

*Data for Turkey exclude foreign citizens.

Source: OECD, based on OECD/UNESCO Institute for Statistics/Eurostat data collection on careers of doctorate holders 2010. 
Figure 25. Satisfaction levels of doctorate holders with principal job by selected criteria II, 2009

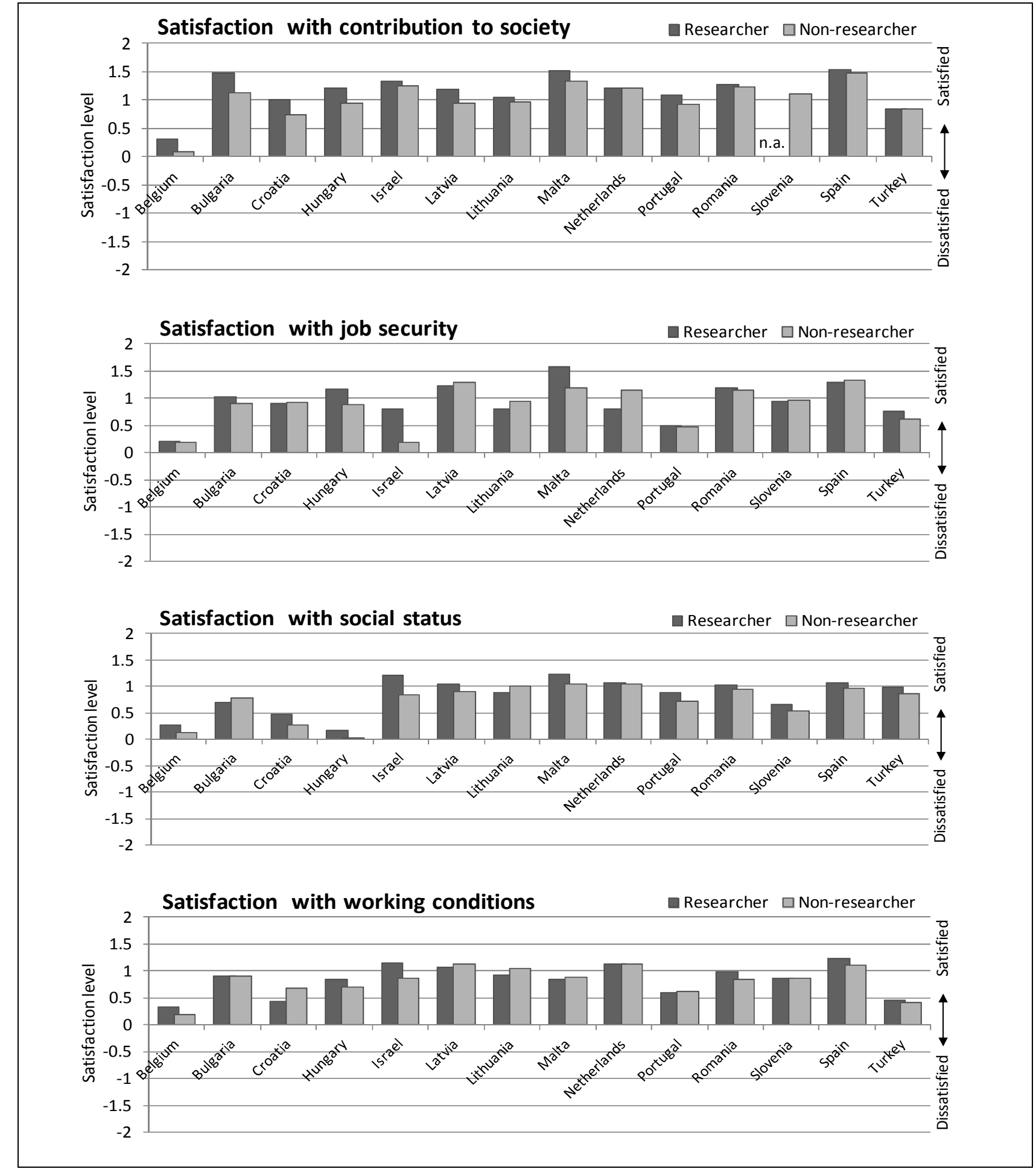

Notes:

* Satisfaction levels of doctorate holders are calculated by assigning values of "+2","+1","-1", and "-2" to four satisfaction levels of "very satisfied", "somewhat satisfied", "somewhat dissatisfied", and "very dissatisfied", respectively.

*Data for Belgium, Hungary, the Netherlands and Spain refer to graduation years 1990 onwards.

*For Spain, there is limited coverage of doctorate holders for the years 2007 to 2009.

*Data for Turkey exclude foreign citizens.

Source: OECD, based on OECD/UNESCO Institute for Statistics/Eurostat data collection on careers of doctorate holders 2010. 
Figure 26. Satisfaction levels of doctorate holders with principal job by selected criteria III, 2009

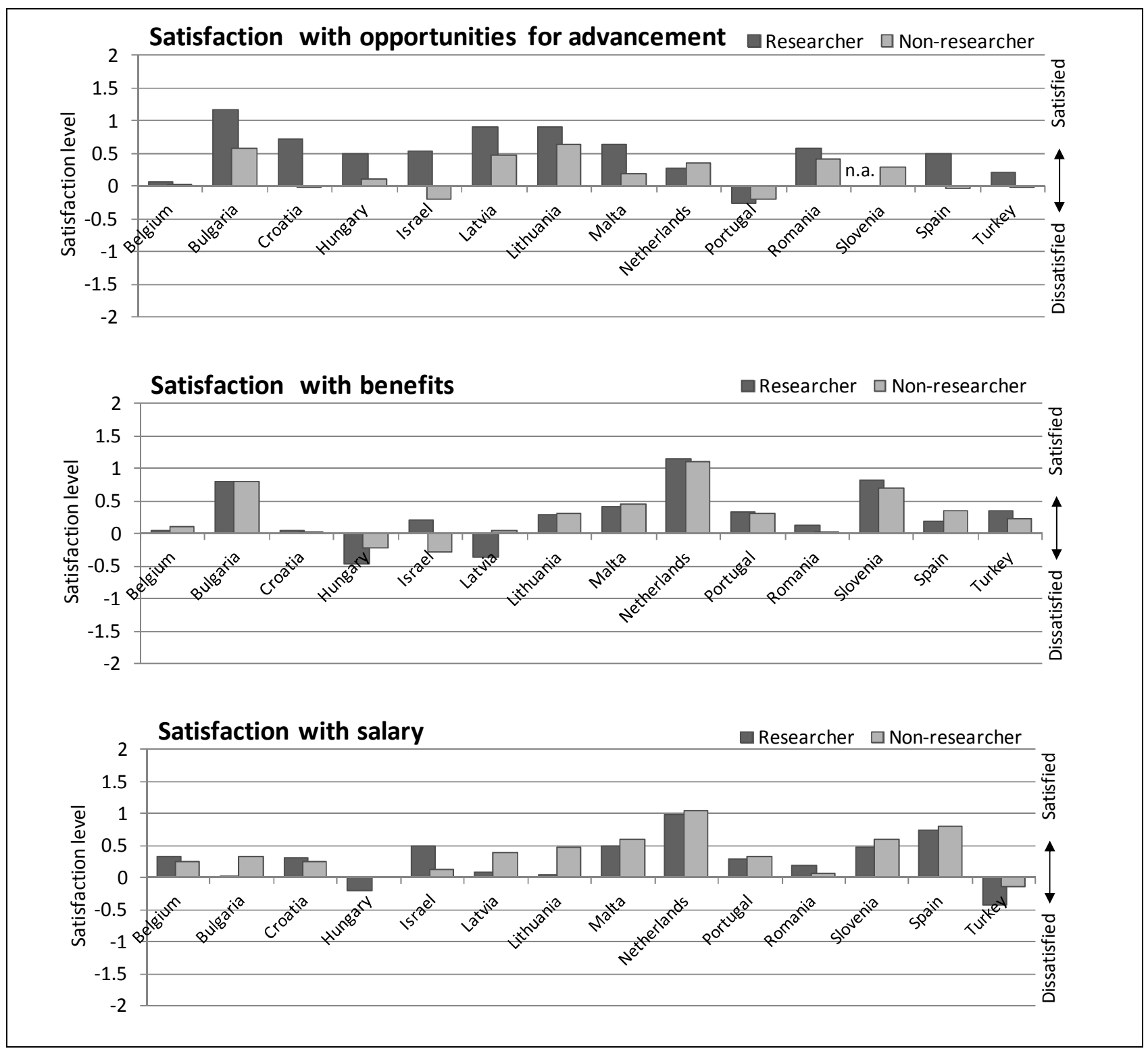

Notes:

* Satisfaction levels of doctorate holders are calculated by assigning values of "+2","+1","-1", and "-2" to four satisfaction levels of "very satisfied", "somewhat satisfied", "somewhat dissatisfied", and "very dissatisfied", respectively.

*Data for Belgium, Hungary, the Netherlands and Spain refer to graduation years 1990 onwards.

*For Spain, there is limited coverage of doctorate holders for the years 2007 to 2009.

*Data for Turkey exclude foreign citizens.

Source: OECD, based on OECD/UNESCO Institute for Statistics/Eurostat data collection on careers of doctorate holders 2010. 


\section{Box 2. Early career researchers in Japan}

At the expert group meeting on Careers of Doctorate Holders (CDH) held in Lisbon in January 2006, a possible international definition of post-doctorates for statistical purposes was discussed. However, it was felt difficult to come up with an agreed definition because of the diversity of status encountered among post-doctorates, not only across countries but also across institutions. The National Institute of Science and Technology Policy (NISTEP) in Japan has been conducting a series of surveys by using the following definition of postdoctoral researchers since FY 2005.

"Those who, after completed doctorates (including withdrawals upon obtaining required credits), (1) engage in research activities at a research organization such as a university, not as a professor, an associate professor, an assistant professor, or the like, or (2) engage in research activities at a research organization such as an independent administrative agency, assigned to the position for a fixed term and are not in a position such as a leader or a senior researcher of their research group."

According to the latest survey results (NISTEP, 2011), as of November 2009, the total number of postdoctoral researchers employed in universities and colleges and in public research institutes was 15,220. The breakdown by research field shows the field of natural sciences had the largest percentage at $31 \%$, followed by engineering at $28 \%$. Among all postdoctoral researchers, the proportions of female and foreign nationals accounted for $25 \%$ and $23 \%$ (the share by nationality was: China 38\%, South Korea 12\%, India 7\%, France 4\%, Bangladesh $3 \%$ ), respectively. Their career status as of April 2010 (12\% of unknown status) revealed that $74 \%$ continued postdoctoral training, $8 \%$ took a university faculty position, $4 \%$ found other R\&D positions including private sector, and $2 \%$ moved out of R\&D labour market after finishing their postdoctoral training.

Referring to the sampling survey carried out in FY2007 (NISTEP, 2008), although the average length of postdoctoral contract was approximately 3 years, individuals with 6 years or longer experience as postdoctoral researchers accounted for $16 \%$ of the total. In particular, it was in the field of natural sciences that the percentage of individuals who continued as postdoctoral researchers for 6 years or longer was the highest (25\%), followed by agricultural sciences (18\%). The detailed analyses based on the latest survey (NISTEP, 2011) can also highlight that for those who worked as postdoctoral researchers as of November 2009, obtaining tenured R\&D positions immediately after postdoctoral training took approximately 3-4 years since the completion of doctoral courses for an assistant professor or lecturer position, 6-7 years for an associate professor position, 8-9 years for a professor position, whereas it took only 3-4 years for those who found a tenured R\&D positions in the private sector. The longer the temporary employment, the harder it becomes for young researchers to balance between family matters and research career. Indeed, more than a half of those who wished to take a parental leave were not able to take one, because of the constraints on the contract, a fear of losing income and positions, etc. Child care issues are not the only limited factors. Among postdoctoral researchers, $52 \%$ of married female postdoctoral researchers are married to researchers, whereas only $12 \%$ of their male counterparts are married to researchers. With the high percentage of female researchers married to male researchers, there are issues linked to the dual-career of these married couples that also put constraints on job-seeking activities, especially for female postdoctoral researchers. Among female postdoctoral researchers with spouses, $44 \%$ of respondents said that they would "Limit range of applications based on circumstances of spouse's job" (compared to $11 \%$ of their married male counterparts); only $5 \%$ replied that their "Spouse adjusts job-searching activities like occupation and location in line with your(their) future career choices" (compared to $41 \%$ among males); and $26 \%$ said they would be forced to "Unavoidably live separately from spouse" (compared to $12 \%$ among males).

\section{Patterns of job-to-job mobility}

44. Knowledge exchange and transfer play an important role in the advancement of research and the dissemination of innovations. One vehicle for knowledge diffusion is the mobility of people between research institutions and different sectors of the economy. $\mathrm{CDH}$ data can be used to document the mobility of individuals with doctorate degrees, a priority question from the perspective of sponsors of $\mathrm{PhD}$ programmes whose objective is to maximise the social and economic benefit of their public investment in training researchers. Voluntary mobility can be expected to improve the quality of the match between doctorate holder and employee and promote knowledge transfer. However, mobility may also be the outcome of unintended separations and represent the breakdown of a stable match, for example as a result of a business closure, or reflect career instability and low attachment. 
45. The data are available for 15 countries and give information on whether doctorate holders have changed jobs over the previous ten years, as well as on their current and previous positions. It is therefore possible to compare mobility of those who are currently employed as researchers with those who are not, as well as the origin and destination sectors of mobility.

46. The data show an average rate of mobility, as measured by the percentage of those doctorate holders who have changed jobs over the previous ten years in total employment, of $26.9 \%$, ranging from $12.8 \%$ in Romania to $76.4 \%$ in Denmark. Mobility rates did not reach $20 \%$ of the total employed doctorate holders the Russian Federation (data are for researchers and teachers only), Bulgaria, Belgium and Romania. By contrast, in addition to Denmark, mobility appears to be particular high in Iceland (62.0\%), Germany $(57.3 \%)$, the Netherlands $(50.6 \%)$ and in Israel $(45.7 \%)$. In the United States, mobility is measured over the previous two years only but reaches an average rate of $25.7 \%$, comparable with that of the other countries for which it is measured over a ten year period, probably indicating a relatively higher rate of mobility over the decade.

47. Data for those doctorate holders having graduated from 1990 onwards, as well as for the total population, are available for two countries - i.e. Latvia and the United States - and reveal rates of mobility that are markedly higher for the most recently graduated population as compared to the total population. In Latvia, the mobility rate of those having graduated in 1990 and subsequent years reaches $30.9 \%$ against $25.4 \%$ for the whole population. In the United States the corresponding percentages are $33.2 \%$ and $25.7 \%$. The relative higher rates of mobility found in Denmark and the Netherlands may partially (but not totally) be explained by this phenomenon since the population covered in those countries are graduates from 1990 onwards. However mobility rates in Belgium and in Spain are also calculated over those doctoral graduates from 1990 and subsequent years and remain relatively low.

48. Although the majority of doctorate holders work as researchers, the average mobility rate is higher for those who are not researchers (32.8\%) compared to researchers (23.9\%), (Figure 27). The only exception to this is the United States where the rate of mobility is slightly higher for those working as researchers $(25.9 \%)$ compared to non-researchers $(25.4 \%)$. There may be different explanations for the fact that non researchers are more mobile than researchers: for example, a higher turnover in business enterprises where non-researchers are primarily employed or better opportunities for career advancement out of research positions. Another possible explanation may be that doctorate holders hop from one job to another until they can secure their position in a research post, especially at the start of the career.

49. Mobility patterns of doctorate holders vary greatly from one country to another (see annex table 3), but a number of similar patterns may be observed across countries. Unsurprisingly, intra-sectoral mobility represents a large share -- at least $45 \%$ in most countries for which data are available -- of total mobility of doctorate holders. In the case of Belgium, it reaches $68.2 \%$ of researcher mobility $(42.9 \%$ in the higher education sector only). For researchers, the higher education sector is the most prominent both in terms of origin and destination sector. In the case of doctoral graduates not working as researchers, it is the business sector which appears to be most prominent both in terms of origin and destination sector. ${ }^{8}$ In Spain however a large share of the mobility of non researchers ends up in the government sector (this is probably due to the importance of the health sector which is classified within the government sector). The patterns of mobility are also somewhat different in the United States: mobility destinations are more or less equally split between the business enterprise and higher education sectors both for researchers and nonresearchers.

8. The business enterprise sector represents the first employment sector of those doctorate holders not working as researchers in Belgium, Latvia, Lithuania, the Netherlands, Poland and Slovenia. 
Figure 27. Doctorate holders having changed jobs in the last 10 years, 2009

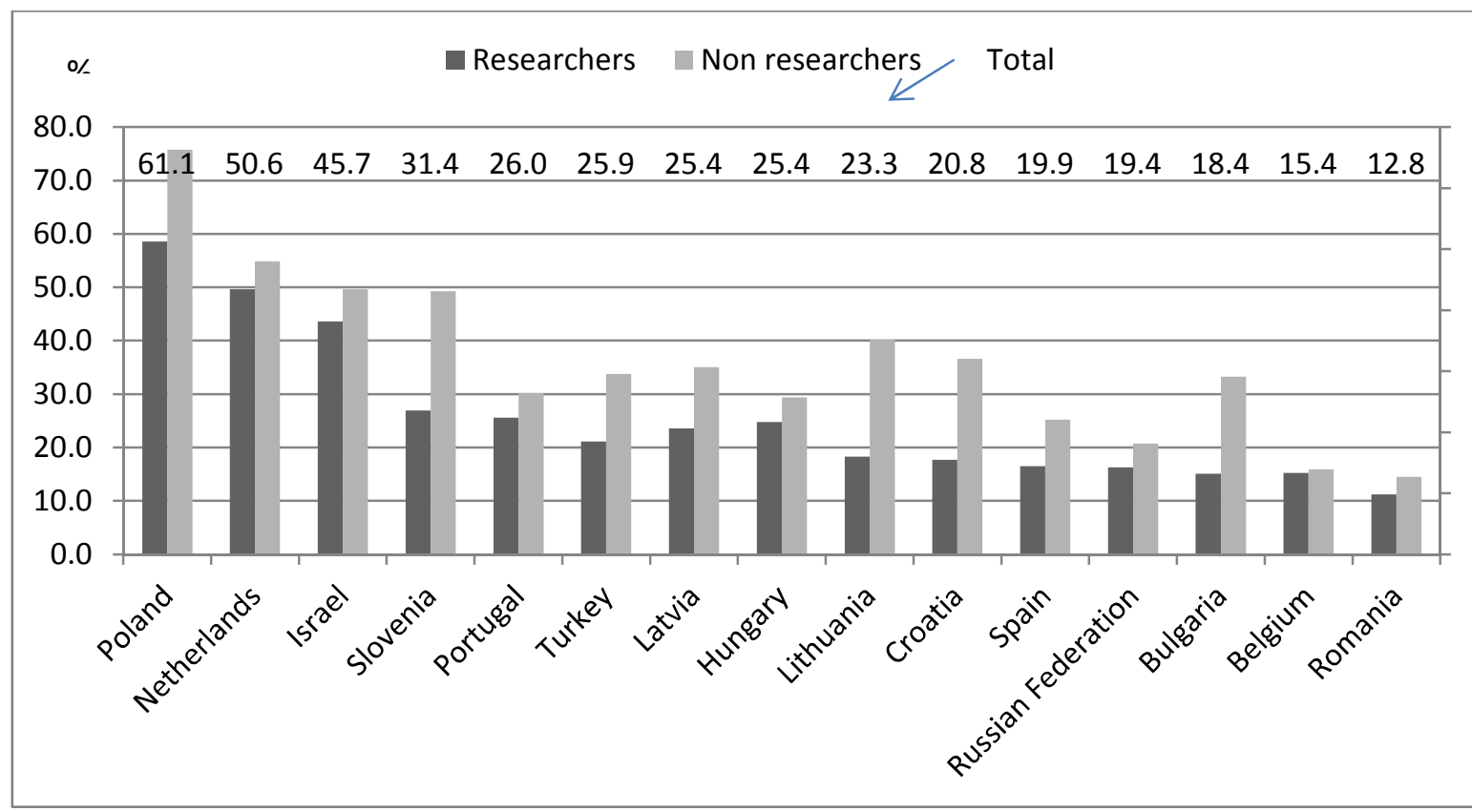

Notes

*Data for Belgium, Germany, Hungary, the Netherlands and Spain refer to graduation years 1990 onwards.

*For the Russian Federation, data relate only to those doctoral graduates employed as researchers and teachers.

*For Spain, there is limited coverage of doctorate holders for the years 2007 to 2009.

*Data for Turkey exclude foreign citizens.

Source: OECD, based on OECD/UNESCO Institute for Statistics/Eurostat data collection on careers of doctorate holders 2010.

50. The question of knowledge transfer between university and industry is of particular interest to policy makers and may be gauged through the mobility of doctorate holders from higher education to enterprises. Such mobility, however, remains moderate: the shares of doctorate holders involved are highest for Slovenia: $20.7 \%$ of those working as researchers and $15.6 \%$ of those not working as researchers. The flows are also relatively high among doctorate holders working as researchers in the Netherlands and among doctorate holders not employed as researchers in Croatia, representing respectively 9.5 and $10.4 \%$ of total mobility flows of the respective populations. Elsewhere, the share of flows involved does not exceed 5\% of total mobility, except in Belgium, Latvia and Lithuania.

51. Interestingly, mobility is more prominent the other way around, i.e. from the business sector towards higher education. Among doctorate holders working as researchers, the flows involved reach $21.0 \%$ in Latvia, $20.7 \%$ in Portugal and $16.1 \%$ in Romania and with the exception of Belgium, the Netherlands and Russia represent at least $5 \%$ in the other countries.

52. Other noticeable types of flows are most probably related to the organisation of the research, labor market or economic systems of the countries involved. For example, mobility flows of doctorate holders are relatively important between the government and higher education sectors in Portugal $(30.1 \%$ of those working as researchers and $14.1 \%$ of those non researchers), in Hungary $(13.2 \%$ of total researcher mobility both ways) and, among those who do not work as researchers, from the government to the business sector (17.5\%) in Turkey, as well as inside the private non-profit sector in the Netherlands (13.3\%). 
53. Additional tabulations produced as part of the KNOWINNO-CDH micro data work will give additional insights on mobility according to field of specialisation and across different occupations, as well as on the influence of gender and type of contracts.

54. Another important aspect of mobility is its international dimension and this is discussed in the next section.

\section{International mobility and the competition for talent}

55. A recent OECD report (Widmaier and Dumont, 2011) reveals that one third of all recent immigrants to the OECD were tertiary educated. This is an effect of the overall expansion of higher education worldwide and of the consequent up-skilling of the population combined with increasing migration flows.

56. Furthermore, the globalisation of the education and research systems associated with policies aimed at attracting the best talents has a boosting effect on the international mobility of the most highly skilled. In a previous paper (Auriol, 2010), we could show that the share of foreign born among doctorate holders is higher than for other tertiary level graduates. In a world in which research is carried out on a truly global basis and personal transport is more affordable than ever, it might be expected that most researcher doctorates should have been exposed to an episode of international mobility in order to draw upon expertise in leading research organisations.

57. The $2009 \mathrm{CDH}$ figures reveal that in the countries for which data is available, an average of $14 \%$ of national citizens with a doctorate have been internationally mobile in the previous 10 years. (Figure 28) This is a low estimate since the data are based on the declarations of returnees and do not take into account those who are currently and may remain abroad. Individuals in countries that host world-leading research organisations may perceive a lesser need to move abroad. However, a number of barriers, including economic and personal costs, language differences and lack incentives may also explain this apparently low mobility rate. Most of the reporting countries are European and the data show that Europe is the main destination region. However, the United States systematically appears among the three first destination countries (Annex table 4). Likewise, the three largest European countries (France, Germany and the United Kingdom) appear among the favourite destinations as well as those countries that have strong historical, cultural or linguistic links with the reporting country. 
Figure 28. International mobility of doctorate holders, by last destination, 2009

Percentage of national citizens with a doctorate who lived/stayed abroad in the past ten years

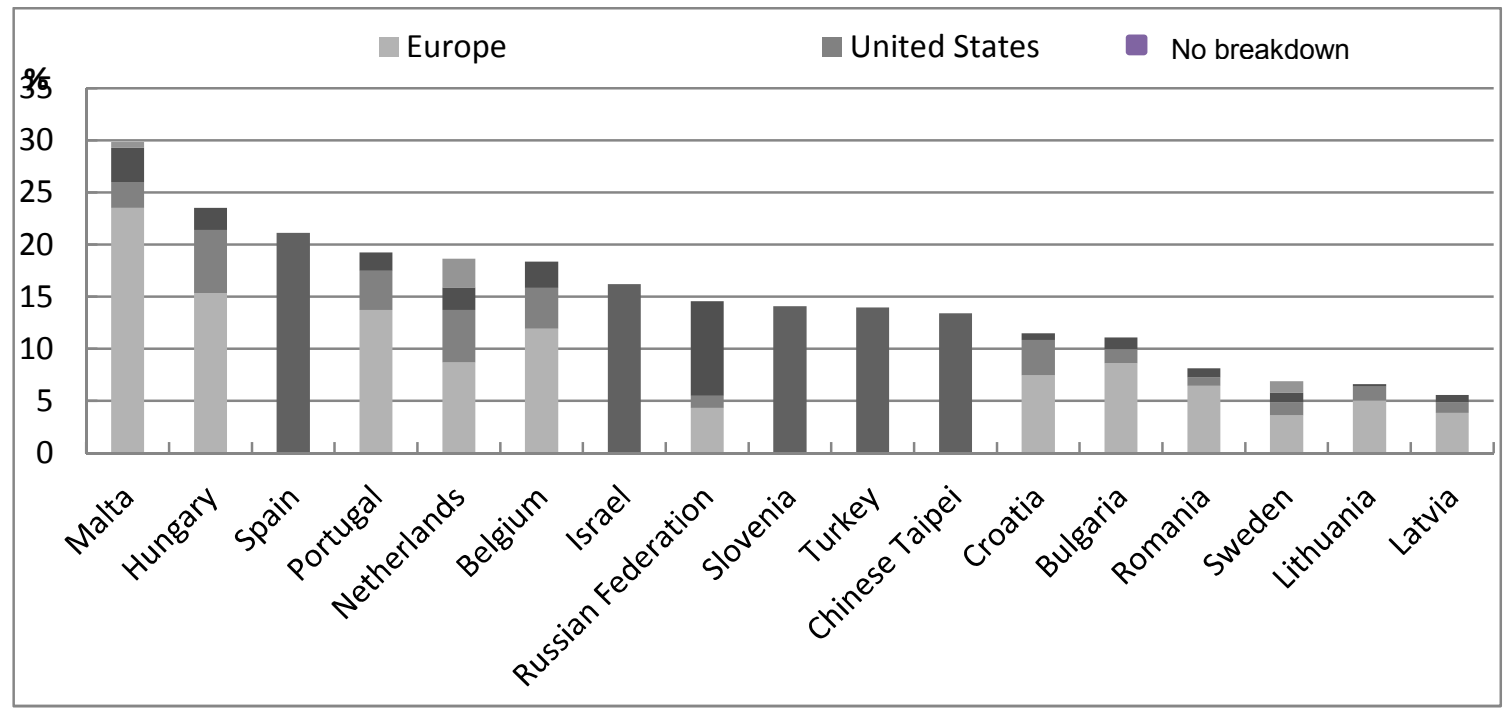

Notes:

*Data for Belgium, Hungary, the Netherlands and Spain refer to graduation years 1990 onwards.

*For Bulgaria, Hungary, Latvia, Malta, Poland, Portugal and Romania, the reporting gap is caused by rounding.

*For the Netherlands and Sweden, the reporting gap is due to data that have not been disclosed for national citizens at the individual country level and respondents that have not been assigned to countries or classified as unknown.

*For the Russian Federation, data relate only to those doctoral graduates employed as researchers and teachers.

*For Spain, there is limited coverage of doctorate holders for the years 2007 to 2009.

*Data for Turkey exclude foreign citizens.

*"Other economies" refer to those located in Africa, America (excluding the United States), Asia, Europe and Oceania.

Source: OECD, based on OECD/UNESCO Institute for Statistics/Eurostat data collection on careers of doctorate holders 2010.

58. At least $60 \%$ of these returnees have been mobile only once during the ten years under review (Figure 29). However, in Hungary, Bulgaria, Romania, Spain and Malta, at least 30\% went abroad between two and four times. In terms of length of stay, the picture is more heterogeneous. With the exception of Hungary, at least $30 \%$ of national citizens with a doctorate spent less than a year abroad over the previous ten years (Figure 30 ). However, in half of the countries, at least $20 \%$ spent one to two years abroad while in Spain, Portugal and Malta, 30\% at least were mobile for a cumulative length of time comprised between two and less than five years.

59. These indicators show the temporary aspect of mobility since they are based, as mentioned above, on the declarations of returnees. They reveal that international mobility is in many cases a one-off and short-term one, although a non negligible share of the population also seems to travel abroad on a more frequent basis and for longer time periods. Such mobility may take place in the context of research exchange programmes between universities: we will see below that academic reasons play an important role in the decision to go abroad. The preliminary results of the KNOWINNO-CDH micro data work also reveal that those doctorate holders who work as researchers as well as those who work in the higher education sector are more mobile than the others.

60. The $\mathrm{CDH}$ data also informs on intentions to move out of the country in the following year. For 11 countries out of 13 , the percentage of those with such intentions is above $5 \%$ and reaches $10.9 \%$ in Portugal, $13.2 \%$ in Hungary and $16.2 \%$ in Turkey. 
Figure 29. Distribution of mobile national doctorate holders by number of stays abroad, 2009

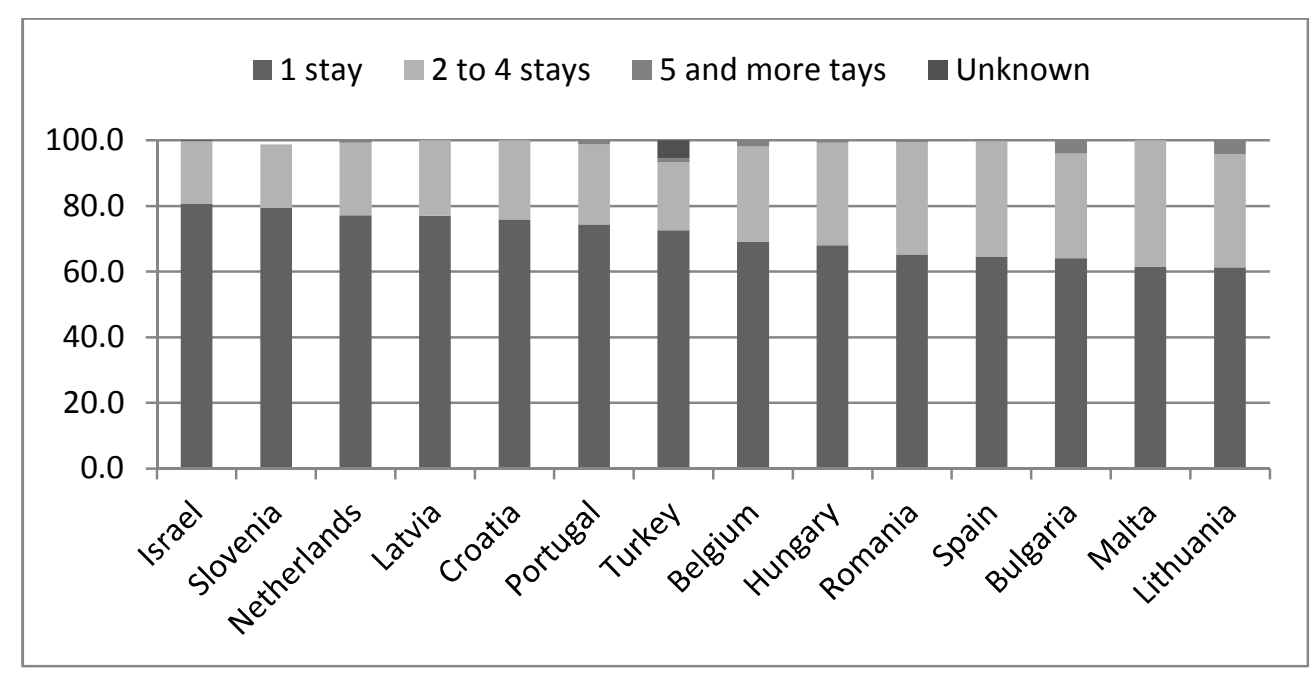

Notes:

*Data for Belgium, Hungary, the Netherlands and Spain refer to graduation years 1990 onwards.

*For the Bulgaria, Hungary, Latvia, Malta, Poland, Portugal and Romania, the reporting gap is caused by rounding.

*For the Netherlands and Sweden, the reporting gap is due to data that have not been disclosed for national citizens at the individual country level and respondents that have not been assigned to countries or classified as unknown.

*"Other economies" refer to those located in Africa, America (excluding the United States), Asia, Europe and Oceania.

*For the Russian Federation, data relate only to those doctoral graduates employed as researchers and teachers.

*For Spain, there is limited coverage of doctorate holders for the years 2007 to 2009.

*Data for Turkey exclude foreign citizens.

Source: OECD, based on OECD/UNESCO Institute for Statistics/Eurostat data collection on careers of doctorate holders 2010.

Figure 30. Distribution of mobile national doctorate holders by length of stay abroad, 2009

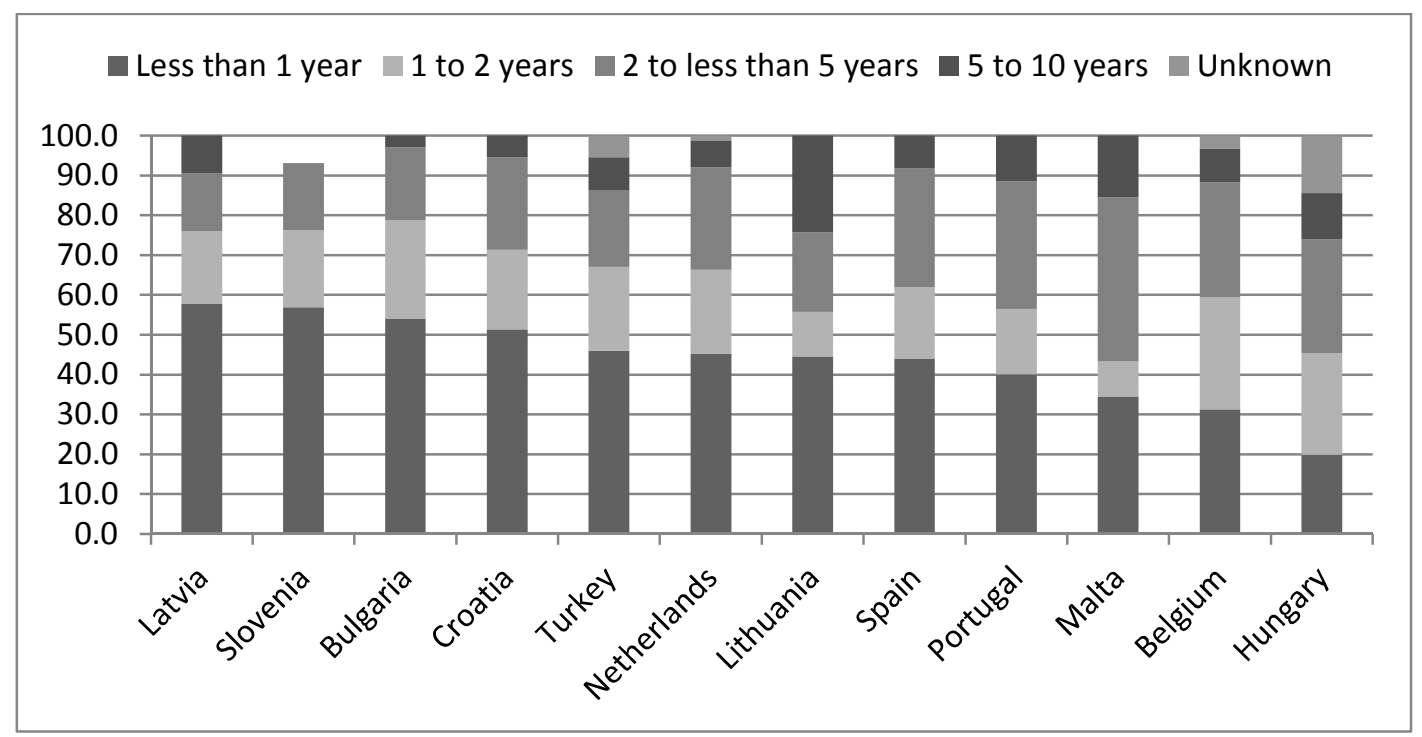

Notes:

*Data for Belgium, Hungary, the Netherlands and Spain refer to graduation years 1990 onwards.

*For the Bulgaria, Hungary, Latvia, Malta, Poland, Portugal and Romania, the reporting gap is caused by rounding.

*For the Netherlands and Sweden, the reporting gap is due to data that have not been disclosed for national citizens at the individual country level and respondents that have not been assigned to countries or classified as unknown.

*"Other economies" refer to those located in Africa, America (excluding the United States), Asia, Europe and Oceania.

*For the Russian Federation, data relate only to those doctoral graduates employed as researchers and teachers.

*For Spain, there is limited coverage of doctorate holders for the years 2007 to 2009.

*Data for Turkey exclude foreign citizens.

Source: OECD, based on OECD/UNESCO Institute for Statistics/Eurostat data collection on careers of doctorate holders 2010. 


\section{DSTI/DOC(2013)4}

61. What are the motivations for international mobility? Three types of reasons can be identified as being prominent in the decision to move: academic factors as mentioned above, other job related or economic factors and family or personal reasons. Their importance is not the same depending on if mobility is inward or outward. Academic factors intervene in the decision of $43.9 \%$ of those doctorate holders with intentions to go abroad in the next year, other job related or economic factors for $30.9 \%$ and family or personal reasons for $15 \%$. For those returning, the equivalent percentages are respectively $27.5 \%, 23.6 \%$ and 20.6\% (Figure 31). There are of course differences across countries and academic reasons seem to be play an important role in the decision to go abroad for those doctorate holders from Portugal (64.1\%), Turkey (57.1\%) and Spain (54.1\%). See more country details in annex tables 5 and 6.

\section{Figure 31. Reasons given by national citizens with a doctorate for going abroad or returning to the home} country, percent, 2009

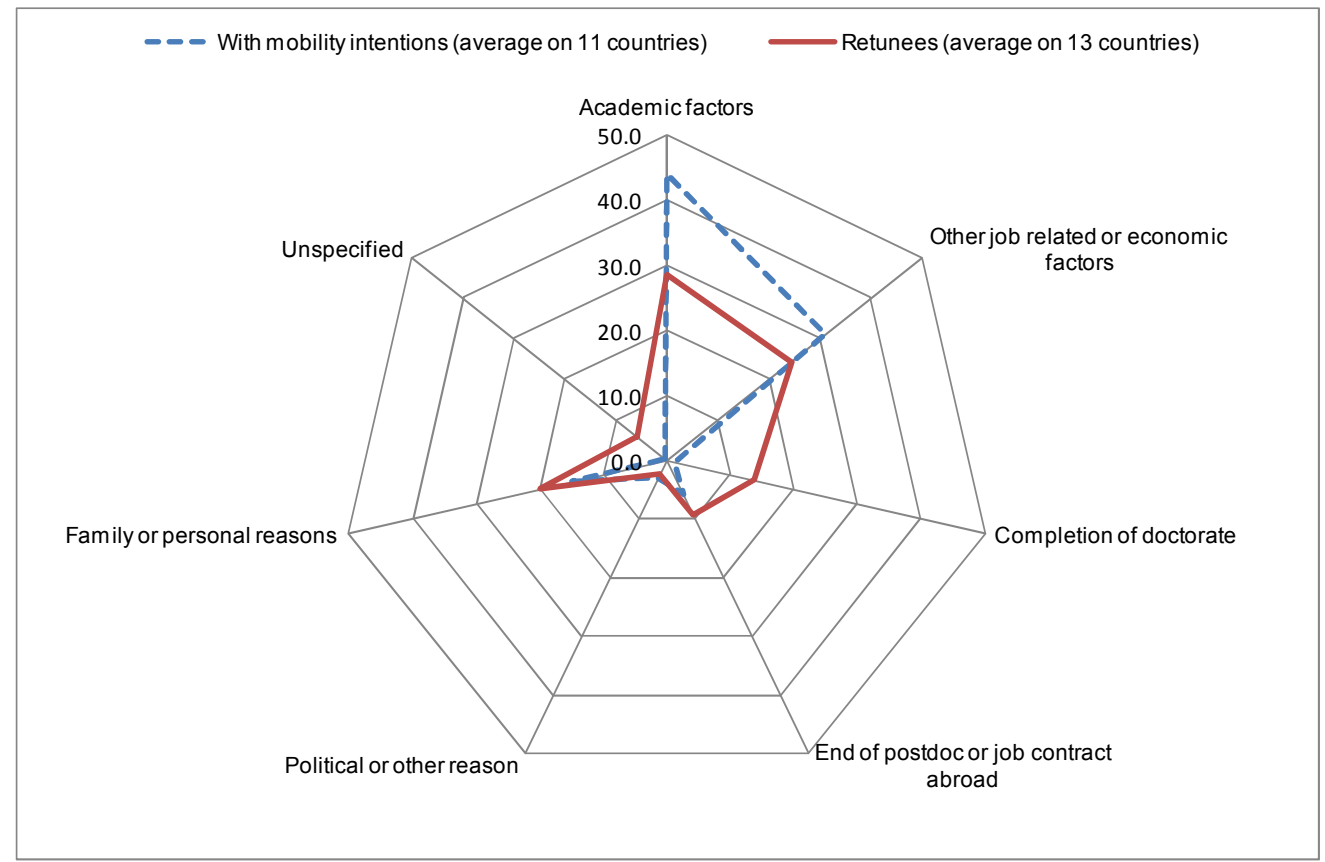

Source: OECD, based on OECD/UNESCO Institute for Statistics/Eurostat data collection on careers of doctorate holders 2010.

62. The KNOWINNO-CDH micro data work will further inform on international mobility patterns according to age, sex, sector of employment, field of science, type of contract, seniority as a researcher as well as involvement in collaboration and networking activities.

63. The above indicators give interesting information on international mobility but do not inform on the migration patterns and possible brain drain of doctorate holders. The data at hand are too sparse and not sufficiently robust to allow such analysis (see methodological information in annex 1). The Database on Immigrants in OECD Countries (DIOC) may however be used to look at migration patterns of doctorate holders in a limited number of OECD countries for which data on individuals having received a doctoral degree are available. 


\section{Box 3. The Database on Immigrants in OECD Countries}

The Database on Immigrants in OECD Countries (DIOC) provides comprehensive and comparative information on a broad range of demographic and labour market characteristics of immigrants living in OECD countries. The database has been compiled in collaboration with OECD national statistical offices. The main sources of data are population censuses and population registers, sometimes supplemented by labour force surveys (http://www.oecd.org/migration/dioc).

A first version of the database was compiled using data from the round of censuses circa 2000. This exercise will be repeated with the census round circa 2010. In the meantime a quinquennial update for 2005/06 was recently made available drawing on existing quinquennial censuses, registers and labour force surveys.

In the 2000/01 version, data on the migrant population having received a degree at the ISCED 6 level was available for two thirds of the OECD countries. In the 2005/06 version, because of the increased used of non census data, in particular labour force surveys for which the sample of doctorate holders might be too limited in size, data for the population at the ISCED 6 level is available for only seven countries, i.e. those countries having quinquennial census or well established population registers: Australia, Canada, Denmark, Finland, Ireland, Sweden, United States. For the latter country, because of the discontinuation of the decennial longer form, the data source used is the American Community Survey (ACS) for which an average of data collected from January 1 , 2007 to December 31, 2009 has been calculated.

The advantage of using this database is that, for some of the above countries, it ensures a full coverage of the foreign and migrant populations compared to the $\mathrm{CDH}$ data. For example, in the case of the United States, those doctorate holders who have received their doctoral degree in a non-US university are covered as well as those who have a doctorate in the humanities. The numbers between the two data sources are therefore different. In the case of the DIOC, the population also covers all individual aged 15 or above in contrast to the CDH data source which covers only individuals below 70 .

For these reasons, the DIOC database provides an interesting and homogenous dataset that can be used to look at the migration patterns of the doctoral population.

64. The recent update of the DIOC reveals that the migrant population - defined as the foreign born population - in the OECD (25 countries) increased by 16.9 million (23\%) between 2000 and 2005/06 (Widmaier and Dumont, 2011). During the same period, the share of the highly educated population living in the OECD countries, increased by 3 percentage points for the native-born and by 5 percentage points for the foreign-born. In 2005/06, about 26 million immigrants holding a university degree were living in the OECD countries. Furthermore, migration of highly educated women increased significantly.

65. In the case of doctorate holders, the data are available for six countries and show a higher growth rate for the foreign-born doctorate holders than for the native-born in four countries: in Denmark there were 1056 foreign born doctorate holders in 2005-06 against 637 in $2000(+65.8 \%)$, in Finland 1928 against $1080(+78.5 \%)$, in Ireland 5392 against $3699(+45.8 \%)$ and in the United States 610056 against $442323(+37.9)$. This is not the case in Australia and Canada although the foreign-born population has also increased significantly: 44589 in 2005-06 against 31279 in $2000(+42.6 \%)$ and 92400 against 69125 $(33.7 \%)$ respectively. The only country that has seen its foreign-born doctoral population decrease is Sweden; from 13420 to $13245(-1.3 \%)$ although the trend has been positive for females from 4775 to 4 $845(+1.5 \%)$. More generally, the growth of the female doctoral population has been much higher than that of its male counterpart for both the native and the foreign-born (see Figure 32). 
Figure 32. Percent change in the number of native-born and foreign-born doctorate holders in seven OECD countries between 2000 and 2005/06

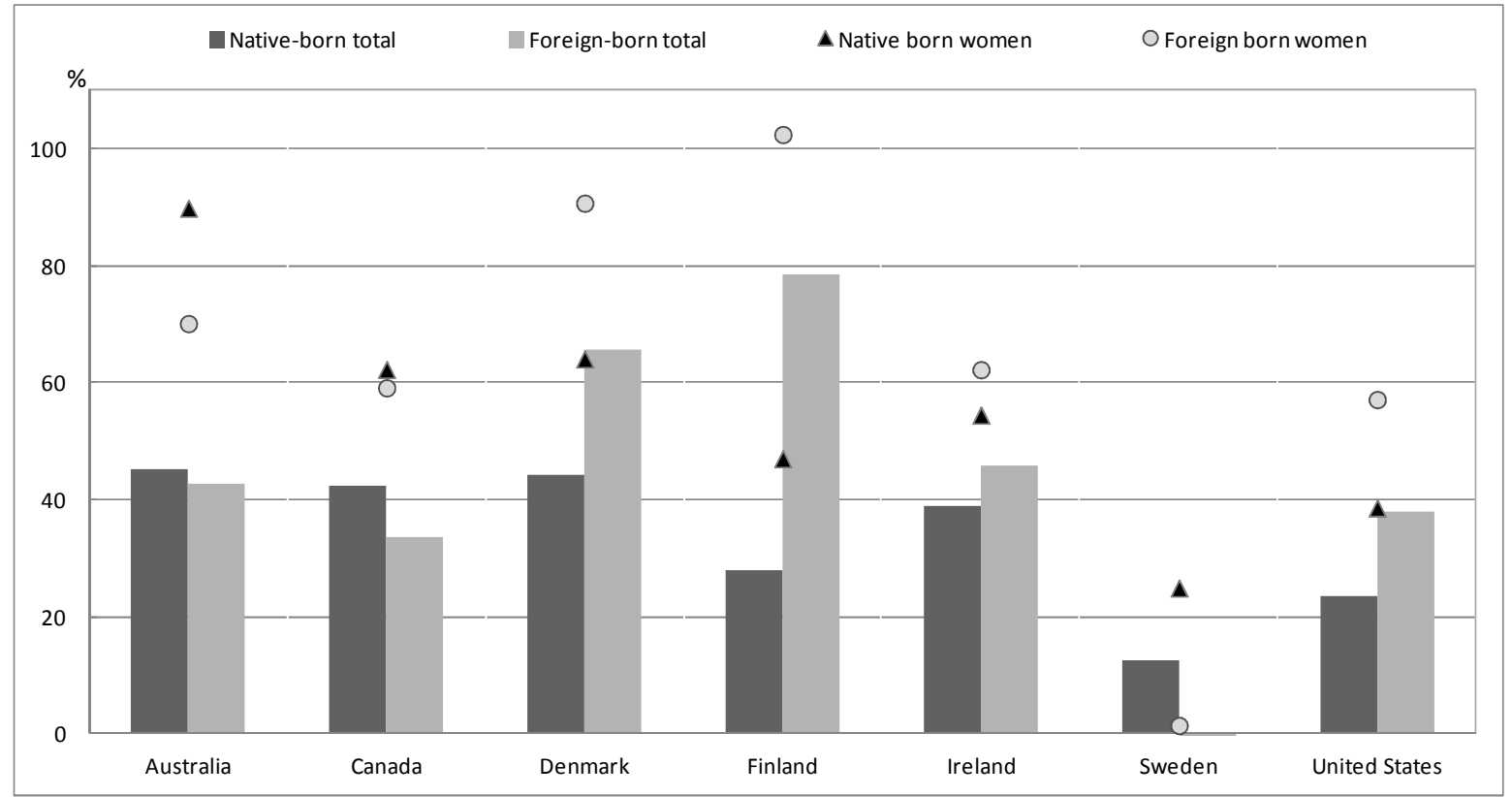

Source: OECD, Database on immigrants in the OECD countries, 2012.

\section{Mobility and emigration of doctorate holders to the United States}

66. Since the end of the second world war, the United States has been a magnet for the research community in Europe and elsewhere in the world, offering particularly attractive infrastructure and working conditions.

67. The DIOC provides for the first time a full picture of the migration trends of the doctoral population to the United States over the period comprised between 2000 and 2005-2009 ${ }^{9}$. There were around 610000 foreign-born doctorate holders in the United States in 2005-2009 representing 27\% of the total population of doctorate holders in this country and an increase of $38 \%$ compared to 2000 . This figure represents the volume or stock of foreign-born doctorate holders, which is the outcome of successive waves of migration or mobility. Some of these individuals may have entered the country a long time ago while others have arrived more recently. Half of these were born in Asia and 28\% in Europe.

68. Close to 100000 doctorate holders were born in China, of which $40 \%$ have US citizenship (annex table 7). ${ }^{10}$ The equivalent numbers for India are 64000 and 54\%. South Korea the United Kingdom, Germany, Canada and Chinese Taipei form a group of economies that each have between 20000 and 30 000 native born doctoral graduates residing in the United States ; the Russian Federation, Mexico, Japan and France between 10000 and 20 000. Not all of these doctorate holders have acquired US citizenship and a non-negligible share may only be in the United States on a temporary basis or short-term visit. Interestingly, many of the above cited countries have also large numbers of doctoral graduates. Some foreign born may however have received their doctoral degree in the United States, but others may have

9. The data are based on the US census for 2000 and on an average from the American Community Survey results over the period 2005-2009 (see Box 3).

10. Most were probably Chinese citizens when they first arrived in the US who subsequently aquired US citizenship although this figure may incude a limited number of US citizens who were born in China. 
come for academic or job related reasons and may also return to their home country as we have seen above.

Figure 33. Share of foreign born doctorate holders with US citizenship by country of birth - Change in percentage points between 2000/01 and 2005/09

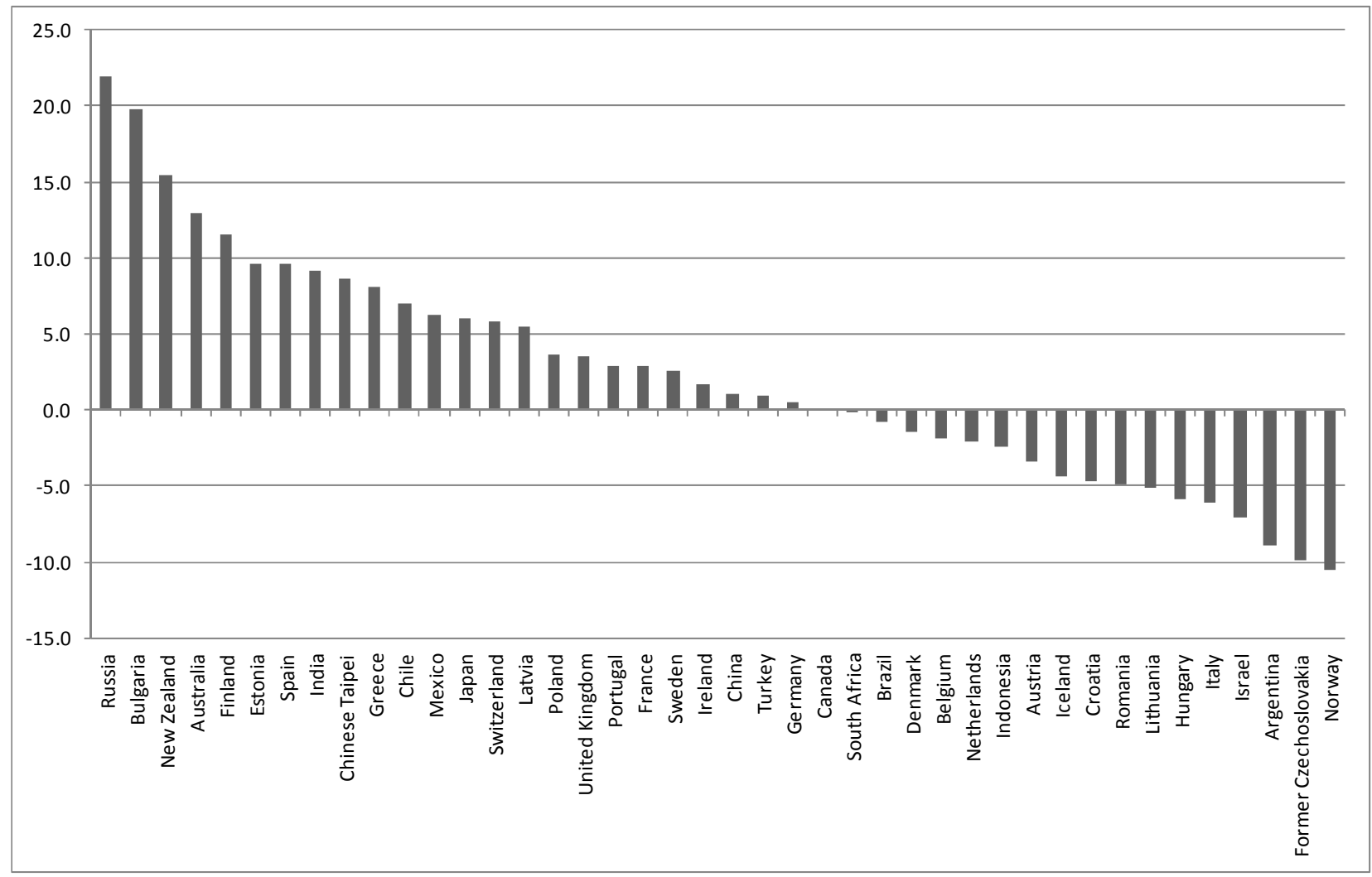

Source: OECD, Database on immigrants in the OECD countries, 2012.

69. Annex table 7 gives the number of foreign-born doctorate holders and share of those having acquired US citizenship, as well as the change in time over the period between 2000 and 2005-2009, for about 45 countries representing $75 \%$ of all foreign-born doctorate holders in the United States. This gives an indicator of brain drain. Figure 33 reveals that the countries for which the progression in the acquisition of US citizenship among doctorate holders has been most steady are the Russian Federation, Bulgaria, Australia and New Zealand, each having seen double their number of natives acquiring US citizenship. The share of native-born who acquired US citizenship has remained stable for Canada, Germany and South Africa and has decreased for two out of five countries, probably indicating that doctorate holders come more for mobility reasons than with the intention to migrate. There may however be a non-negligible share of foreign-born who, without acquiring the US citizenship, will settle in the United States for a long time.

70. These numbers should be compared with the total stock of doctorate holders in the origin country. This is done in Figure 34 using as a denominator data from DIOC where available and data from $\mathrm{CDH}$ for the other countries. The data show that for countries like Australia, Germany and the Russian Federation, the share of native doctorate holders residing in the United States does not exceed 5\% of those in the country while it is three times higher for Ireland, Canada and Israel and exceeds $20 \%$ in smaller countries like Iceland, Slovenia and Latvia. 
Figure 34. Number of foreign born doctorate holders residing in the United States as a percentage of total doctorate holders in the country of birth, 2005-2009

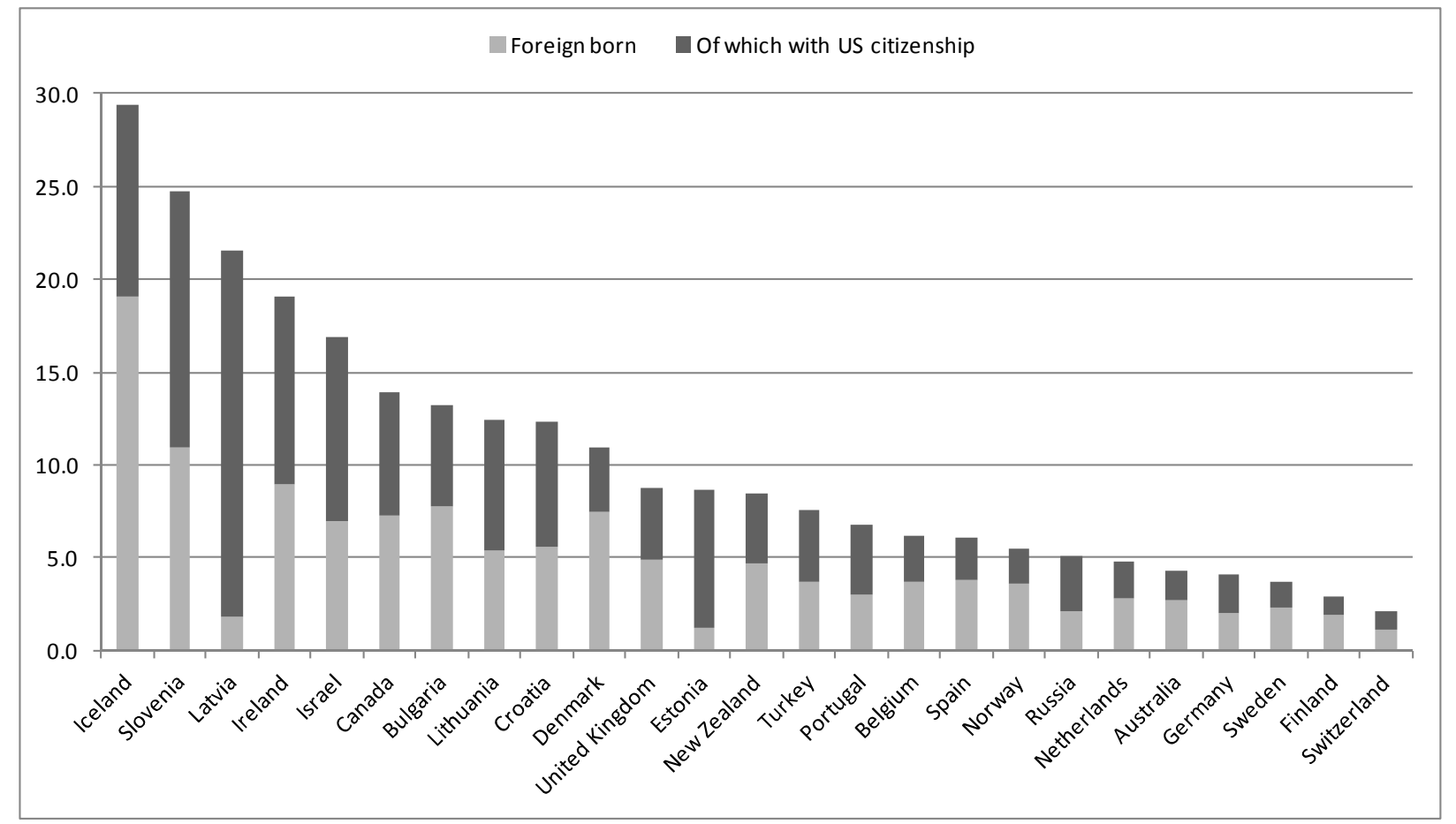

Source: OECD estimates based on the database on immigrants in the OECD countries 2012 and the OECD/UNESCO Institute for Statistics/Eurostat data collection on careers of doctorate holders 2010.

71. This analysis has shown that both international mobility and migration of doctorate holders have increased over the past decade. However, while the United-States has continued attracting many foreign born among doctoral graduates since 2000, a variety of indicators, of which the number of visa deliveries, point to a decline in the immigration of foreign scientists and engineers during the recent economic downturn according to the recent findings from the National Science Board 2012 S\&E indicators (NSB, 2012). It will be interesting to see how this involves in the future.

\section{Conclusions}

72. The $\mathrm{CDH}$ initiative has been continuously evolving and learning from previous experiences over its relatively short history. The present analysis has at the same time confirmed a number of findings from the previous $\mathrm{CDH}$ data collection and shed light on new ones. Most importantly, the results presented in this document showcase the potential of $\mathrm{CDH}$ data to inform policy questions that bear on the labour market and careers of doctorate holders and researchers. Throughout the project, a number of topics have raised particular interest among the participating research teams, pointing to future areas of survey development for testing. Indeed, the changing economic environment, the increasing diversity of career patterns and the changes in the organisation of the research landscape may require the use of a different and broader set of skills. This dimension needs to be measured and analysed with the appropriate tools. The revised methodological guidelines and model questionnaire include proposals for capturing information that is relevant to these questions. $\mathrm{CDH}$ data can also provide a useful tool for analysing the contribution of doctorate holders to entrepreneurship. There is increase interest in the phenomenon of academic entrepreneurship; and observers have also noted the importance of doctorate training for individuals who started, but never completed their doctoral studies as they chose to develop their inventions by starting up new businesses. The next data collection efforts should help shedding light on these new areas of interest. 


\section{REFERENCES}

Auriol, L. (2010), "Careers of Doctorate Holders: Employment and Mobility Patterns", OECD Science, Technology and Industry Working Papers, 2010/04, OECD Publishing. http://dx.doi.org/10.1787/5kmh8phxvvf5-en

Calmand and Vera (2011), Insertion des sortants du supérieur : les effets contrastés de la professionnalisation, Bref du CEREQ, $\mathrm{n}^{\circ}$ 294-2, 2011, 4 p.

EC (2007), Remuneration of Researchers in the Public and Private sectors by CARSA, European Commisson (2007)

Harfi and Auriol (2010), the Employability Problems of doctorate Holders: Explaining a "French Exception", La note d'analyse numéro 189, Centre d'Analyse Stratégique.

Institut de France (2008), Institut de France, Académie des sciences, "Report: Attractiveness of careers in research" (2008).

NISTEP (2011), NISTEP Research Material No. 202, "Survey on Postdoctoral Fellows regarding employment and moving-out situations (FY2009)", 2011.

NISTEP (2008), NISTEP Research Material No. 161, "Investigative Survey on the Research Activities and Awareness of Postdoctoral Fellows: Analysis on Career Choices of Postdoctoral ScholarsInvestigative Survey on the Research Activities and Awareness of Postdoctoral Fellows" (2008).

NSB 2012, National Science Board, 2012 S\&E indicators.

OECD (2008), Paulo Santiago, Karine Tremblay, Ester Basri and Elena Arnal, "Tertiary Education for the Knowledge Society", Vol. 2, OECD, Paris, 2008.

OECD (2010), Skills for Innovation and Research, OECD Innovation Strategy, OECD 2010

OECD (2011), Education at a glance 2011: OECD indicators, OECD, Paris.

OECD (2011b), OECD Science, Technology and Industry Scoreboard 2011, OECD, Paris.

OECD (2012), Transferable Skills Training for Researchers: Supporting Career Development and Research, OECD, Paris, forthcoming.

OSTP (2004), President's council of advisors on science and technology, "Sustaining the Nation's Innovation Ecosystem: Maintaining the Strength of Our Science \& Engineering Capabilities" (2004).

Science (2012), A Stellar Opportunity By Beryl Lieff Benderly by Beryl Lieff Benderly, July 06, 2012, http://sciencecareers.sciencemag.org/career_magazine/previous_issues/articles/2012_07_06/caredit.a 1200075

Widmaier, and Dumont (2011), "Are recent immigrants different? A new profile of immigrants in the OECD based on DIOC 2005/06", OECD Social, Employment and Migration Working Papers No. 126, Directorate for Employment, Labour and Social Affairs, OECD Publishing, http://dx.doi.org/10.1787/5kg3ml17nps4-en 


\section{ANNEX 1 \\ THE CAREERS OF DOCTORATE HOLDERS PROJECT (CDH): DESCRIPTION AND METHODOLOGY}

\section{Background}

With a view to better understand the labour market, career path and mobility of a population, which is seen as being key to the production and diffusion of knowledge and innovation, the OECD, in coordination with the UNESCO Institute for Statistics and Eurostat launched in 2004 a specific project on the Careers of Doctorate Holders $(\mathrm{CDH})$. The two first years of the project were devoted to the methodological developments and a pilot data collection. A network of experts formed of official statisticians was built and worked at identifying the various data sources that could be utilized at national level to build registers of doctoral graduates or produce statistical data. The Expert Group also worked with the three intergovernmental organizations to develop the three components of the technical guidelines: a model survey questionnaire, methodological guidelines and a set of output tables for the collecting data at the international level.

A pilot data collection was organized in 2005 in which seven countries - Argentina, Australia, Canada, Germany, Portugal, Switzerland and the United States -- participated. The results of this first data collection were presented in the OECD working paper DSTI/DOC(2007)2 (Auriol, 2007) and were used to improve the methodology and guidelines of the project described above. ${ }^{11 .}$

A first large-scale data collection was then launched in November 2007 in which some 25 countries participated, most of them European and benefitting from financial support by Eurostat. ${ }^{12}$. This collection provided a rich set of data and metadata, the results of which were extensively discussed in a workshop and expert group meeting in December 2008. A database was built and a first set of indicators were released on the OECD dedicated Web site (www.oecd.org/sti/cdh). The data were further analyzed in a working paper DSTI/DOC(2010)4 (Auriol, 2010) and the technical guidelines revised in DSTI/DOC(2010)1 (Auriol, Felix, Schaaper, 2010). ${ }^{13}$

11. See http://www.oecd.org/dataoecd/17/57/38055153.pdf

12. Australia, Austria, Belgium, Bulgaria, Canada, Croatia, Czech Republic, Cyprus, Denmark, Estonia, Finland, Germany, Iceland, Latvia, Lithuania, Netherlands, Norway, Poland, Portugal, Romania, Slovakia, Spain, Sweden, Switzerland, United States.

13. See http://www.oecd.org/dataoecd/46/43/44893058.pdf and http://www.oecd.org/dataoecd/46/43/44893058.pdf. 


\section{The 2010 CDH data collection}

The second large scale data collection also benefitted from the participation of 25 countries. ${ }^{14}$. The data to be reported by the participating countries were on the situation of doctorate holders as of 1 December 2009. In this section we describe the methodological approach adopted by the reporting countries and how some differences in the data sources and coverage of the target population may affect the comparability of the data. Country details are found in table A at the end of this annex.

\section{Main data sources used to report $\mathrm{CDH}$ data}

One of the most difficult challenges in the CDH exercise is for each country to find the best way to build a directory of its doctoral graduate population. Some recommendations are given in the methodological guidelines on how to do this.

We can distinguish two types of different approaches and eventually two different groups of countries:

1. Those using already existing surveys and/or registers (or administrative data) to report CDH data

2. Those using the $\mathrm{CDH}$ model survey questionnaire and hence having built a specific register of doctorate holders.

In the first group, we find two economies that have used their labour force survey to report CDH data (Germany and Switzerland), those relying on their population registers (Denmark, Finland, Norway and Sweden) and one using an already existing database (i.e Chinese Taipei). ${ }^{15}$ All the other countries have conducted a $\mathrm{CDH}$ dedicated survey as recommended in the methodological guidelines.

The United States however represent a case in point in the sense that it uses data derived from long and well established surveys on which the $\mathrm{CDH}$ survey is to a great extent inspired.

The use of these different data sources has an impact on both the coverage of the target population and the coverage of the variables to be reported as explained below.

\section{Differences in coverage}

The target population as defined in the $\mathrm{CDH}$ methodological guidelines is: 'all individuals having an education at ISCED 6 level (doctorates) obtained anywhere in the world, and being resident (permanent or non-permanent) within the national borders of the surveying countries'. The main challenge in making this definition operational has to do with the coverage of foreign citizens and those with a doctoral degree obtained abroad.

This challenge is less problematic in those countries relying on labour force surveys (or censuses) and such register data (although part of the foreign doctoral graduates may not be fully registered in those latter

14. Belgium, Bulgaria, Croatia, Denmark, Finland, Germany, Hungary, Iceland, Israel, Latvia, Lithuania, Malta, Netherlands, Norway, Poland, Portugal, Romania, Russian Federation, Slovenia, Spain, Sweden, Switzerland, Chinese Taipei, Turkey, United States.

15. Germany however has decided to move to a dedicated survey that will be conducted in 2012 . This survey will not only cover doctorate holders, but also other higher education graduates. 
administrative sources). ${ }^{16}$ For those countries having dedicated $\mathrm{CDH}$ surveys, foreign citizens or graduates who obtained their doctorate abroad are in most cases under-covered.

In the case of the United States, the sample of doctorate holders is updated with foreign citizens and those with non-US doctoral degrees at the time of the decennial census. Else the target population only covers those graduates with doctoral degrees obtained in the United States.

It may also be challenging to achieve full coverage of other segments of the target population, e.g those who received their doctoral degrees many years ago, those who are not active or who are unemployed. Furthermore, once constructed, keeping a register of doctorate holders updated with the new graduates is difficult in certain countries. In such cases, there are a few other limitations as regards the coverage of the target population in some countries:

- Data for Belgium, Germany, the Netherlands and Spain refer only to graduation years from 1990 and onwards.

- For Romania, unemployed and inactive doctorate holders are underestimated.

- For the Russian Federation, data relate only to those doctoral graduates employed as researchers and teachers.

- For Spain, there is limited coverage of doctorate holders for the years 2007 to 2009.

- Data for the United States exclude doctorate holders in the humanities

It is also worth mentioning that while those countries that use labour force survey and register data achieve a better coverage of the target population, they can report only for a limited number of variables that have to do with the main population, labour force and employment characteristics of doctorate holders and not for those specific $\mathrm{CDH}$ variables regarding e.g. perception of the employment situation or international mobility.

Countries using labour force surveys are also limited by the sample size of the doctorate holder population for reporting on certain variables.

Other less important limitations are signalled in the notes attached to the graphs and tables of this paper and further methodological information is available in the Eurostat document 'Evaluation of the CDH 2009 data collection exercise' (Doc.Eurostat/F4/CDH/2011/2/Rev.1).

16. In the previous data collection, as well as probably in the future, some countries also used their census to report $\mathrm{CDH}$ data or build their directory of doctorate holders. 
DSTI/DOC(2013)4

Table A. Main characteristics of the national CDH primary data sources and surveys - 2010 data collection

\begin{tabular}{|c|c|c|c|c|c|c|}
\hline Country & $\begin{array}{l}\text { Primary data } \\
\text { source }\end{array}$ & Reference year(s) & Web based survey & $\begin{array}{c}\text { Sample or census } \\
\text { size (value) and/or } \\
\text { sample rate (\%) }\end{array}$ & Sampling method & $\begin{array}{l}\text { Response } \\
\text { rate }\end{array}$ \\
\hline Belgium & $\begin{array}{l}\text { CDH dedicated } \\
\text { sample survey }\end{array}$ & 2009 & Yes & -- & Stratified sampling & $28 \%$ \\
\hline Bulgaria & $\begin{array}{l}\text { CDH dedicated } \\
\text { sample survey }\end{array}$ & 2009 & No & $2,000 / 13 \%$ & $\begin{array}{l}\text { Stratified sampling } \\
\text { by region }\end{array}$ & $55 \%$ \\
\hline Croatia & $\begin{array}{l}\text { CDH dedicated } \\
\text { sample survey }\end{array}$ & 2009 & $\begin{array}{l}\text { On-line } \\
\text { questionnaire } \\
\text { available on the } \\
\text { website of CBS } \\
\text { Croatia and paper } \\
\text { questionnaire } \\
\end{array}$ & 2,502 / $28 \%$ & $\begin{array}{l}\text { Stratified sampling } \\
\text { by age, sex and } \\
\text { fields of science }\end{array}$ & $43 \%$ \\
\hline Denmark & Register data & $2008 / 2009$ & -- & -- & -- & -- \\
\hline Finland & Register data & 2008 & -- & - & -- & -- \\
\hline Germany & Labour force survey & 2009 & - & - & - & - \\
\hline Hungary & $\begin{array}{l}\text { CDH dedicated } \\
\text { census }\end{array}$ & 2009 & $\begin{array}{l}\text { Electronic and } \\
\text { paper } \\
\text { questionnaires }\end{array}$ & -- & -- & $23 \%$ \\
\hline Iceland & $\begin{array}{l}\text { CDH dedicated } \\
\text { census }\end{array}$ & 2009 & $\begin{array}{l}\text { Internet survey. } \\
\text { The respondents } \\
\text { were sent a } \\
\text { username and } \\
\text { password with a } \\
\text { paper letter. }\end{array}$ & $600 / 30 \%$ & Random sampling & $61 \%$ \\
\hline Israel & $\begin{array}{l}\text { CDH dedicated } \\
\text { sample survey }\end{array}$ & 2009 & $\begin{array}{l}\text { Paper } \\
\text { questionnaire sent } \\
\text { by mail, internet } \\
\text { questionnaire and } \\
\text { CATI (Computer- } \\
\text { Assisted Telephone } \\
\text { Interviewing). }\end{array}$ & $7 \%$ & $\begin{array}{l}\text { Stratified sampling } \\
\text { by sex, age and } \\
\text { economic } \\
\text { branch/occupation }\end{array}$ & $82 \%$ \\
\hline Latvia & $\begin{array}{l}\text { CDH dedicated } \\
\text { sample survey }\end{array}$ & 2009 & $\begin{array}{l}\text { Computer assisted } \\
\text { face-to-face or } \\
\text { telephone } \\
\text { interviews and by } \\
\text { e-mail }\end{array}$ & $43 \%$ & -- & $65 \%$ \\
\hline Lithuania & $\begin{array}{l}\text { CDH dedicated } \\
\text { sample survey }\end{array}$ & 2009 & $\begin{array}{l}\text { Paper } \\
\text { questionnaire only }\end{array}$ & $1,408 / 25.7 \%$ & $\begin{array}{l}\text { Stratified sampling } \\
\text { by age and fields of } \\
\text { science }\end{array}$ & $57 \%$ \\
\hline Malta & $\begin{array}{l}\mathrm{CDH} \text { dedicated } \\
\text { census }\end{array}$ & 2009 & Paper postal survey & 556 & -- & $75 \%$ \\
\hline Netherlands & $\begin{array}{l}\mathrm{CDH} \text { dedicated } \\
\text { sample survey }\end{array}$ & 2009 & $\begin{array}{l}\text { Internet survey } \\
(\mathrm{CAWI})\end{array}$ & $43 \%$ & -- & $54 \%$ \\
\hline Norway & Register data & & & & -- & \\
\hline Poland & $\begin{array}{l}\text { CDH dedicated } \\
\text { sample survey }\end{array}$ & 2008 & $\begin{array}{l}\mathrm{CDH} \text { e- } \\
\text { questionnaire }\end{array}$ & $40 \%$ & -- & $7 \%$ \\
\hline Portugal & $\begin{array}{l}\text { CDH dedicated } \\
\text { sample survey }\end{array}$ & 2009 & $\begin{array}{l}\text { Web and paper } \\
\text { questionnaires }\end{array}$ & $30 \%$ & $\begin{array}{l}\text { Stratified sampling } \\
\text { by sex, age class, } \\
\text { field of science and } \\
\text { year of doctorate } \\
\text { awarded }\end{array}$ & $71 \%$ \\
\hline Romania & $\begin{array}{l}\mathrm{CDH} \text { dedicated } \\
\text { sample survey }\end{array}$ & 2008 & -- & 15,215 & -- & $49 \%$ \\
\hline $\begin{array}{l}\text { Russian } \\
\text { Federation }\end{array}$ & $\begin{array}{l}\text { CDH dedicated } \\
\text { sample survey }\end{array}$ & 2009 & -- & $3,450 / 1 \%$ & $\begin{array}{l}\text { Stratified sampling } \\
\text { by region, age and } \\
\text { fields of science }\end{array}$ & -- \\
\hline Slovenia & $\begin{array}{l}\text { CDH dedicated } \\
\text { sample survey }\end{array}$ & 2009 & $\begin{array}{l}\text { Postal and } \\
\text { telephone } \\
\text { questionnaire }\end{array}$ & $2,114 / 28.5 \%$ & $\begin{array}{l}\text { Statified sampling } \\
\text { by sex, age groups, } \\
\text { doctorate holders } \\
\text { and main fields of } \\
\text { science }\end{array}$ & $66 \%$ \\
\hline
\end{tabular}


DSTI/DOC(2013)4

\begin{tabular}{|c|c|c|c|c|c|c|}
\hline Country & $\begin{array}{l}\text { Primary data } \\
\text { source }\end{array}$ & Reference year(s) & Web based survey & $\begin{array}{c}\text { Sample or census } \\
\text { size (value) and/or } \\
\text { sample rate (\%) }\end{array}$ & Sampling method & $\begin{array}{l}\text { Response } \\
\text { rate }\end{array}$ \\
\hline Spain & $\begin{array}{l}\text { CDH dedicated } \\
\text { sample survey }\end{array}$ & 2009 & $\begin{array}{l}\text { Yes }+ \text { paper }+ \\
\text { interviews }\end{array}$ & 6,000 & $\begin{array}{l}\text { Stratified sampling } \\
\text { by region and age }\end{array}$ & $69 \%$ \\
\hline Sweden & Register data & 2009 & & & & \\
\hline Switzerland & Labour force survey & 2009 & -- & -- & -- & - \\
\hline Chinese Taipei & $\begin{array}{l}\text { Administrative } \\
\text { sources }\end{array}$ & 2009 & & & & \\
\hline Turkey & $\begin{array}{l}\text { CDH dedicated } \\
\text { sample survey }\end{array}$ & 2009 & $\begin{array}{l}\text { Combination of } \\
\text { face-to-face, web- } \\
\text { based and postal } \\
\text { survey }\end{array}$ & $10,433 / 10 \%$ & $\begin{array}{l}\text { Stratified sampling } \\
\text { by sex and age } \\
\text { group }\end{array}$ & $78 \%$ \\
\hline United States & $\begin{array}{l}\text { CDH dedicated } \\
\text { sample survey }\end{array}$ & $2003 / 2008$ & $\begin{array}{l}\text { Paper } \\
\text { questionnaire, } \\
\text { online } \\
\text { questionnaire, } \\
\text { computer assisted } \\
\text { telephone interview }\end{array}$ & $40,000 / 6 \%$ & $\begin{array}{l}\text { Stratified sampling } \\
\text { by citizenship, } \\
\text { race/ethnicity, } \\
\text { disability status, } \\
\text { gender, degree } \\
\text { field }\end{array}$ & $81 \%$ \\
\hline
\end{tabular}

Source: OECD, OECD/UNESCO Institute for Statistics/Eurostat data collection on careers of doctorate holders 2010. 
DSTI/DOC(2013)4

ANNEX 2

ANNEX TABLES 


\section{Annex table 1. Total doctorate holders, by labour force status, 2009}

\begin{tabular}{|c|c|c|c|c|c|c|c|c|c|c|c|c|c|c|c|c|c|c|c|}
\hline & \multirow{2}{*}{$\begin{array}{c}\text { Refere } \\
\text { nce } \\
\text { year }\end{array}$} & \multicolumn{4}{|c|}{ Total employed } & \multicolumn{3}{|c|}{ Unemployed } & \multicolumn{4}{|c|}{ Inactive } & \multicolumn{4}{|c|}{ Unspecified situation } & \multicolumn{3}{|c|}{ Total } \\
\hline & & Men & Women & Unknown & Total & Men & Women & Total & Men & Women & Unknown & Total & Men & Women & Unknown & Total & Men & Women & Total \\
\hline Belgium & 2009 & 94.8 & 93.8 & 87.5 & 94.5 & 1.1 & 2.0 & 1.4 & 1.1 & 2.0 & 6.3 & 1.4 & 2.9 & 2.2 & 6.3 & 2.7 & 100.0 & 100.0 & 100.0 \\
\hline Bulgaria & 2009 & 93.5 & 94.3 &.. & 93.8 & 1.0 & 0.3 & 0.7 & 5.5 & 5.3 &.. & 5.4 &.. &.. & .. & .. & 100.0 & 100.0 & 100.0 \\
\hline Croatia & 2009 & 93.7 & 93.4 &.. & 93.6 & 0.8 & 0.6 & 0.7 & 5.4 & 5.9 &.. & 5.6 &.. &.. &.. &.. & 100.0 & 100.0 & 100.0 \\
\hline Denmark & 2008 & 95.3 & 94.2 &.. & 94.9 & 0.4 & 0.6 & 0.5 & 4.2 & 5.2 &.. & 4.6 & .. &.. &.. &.. & 100.0 & 100.0 & 100.0 \\
\hline Finland & 2008 & 85.3 & 87.0 &.. & 86.0 & 1.9 & 2.4 & 2.1 & 12.8 & 10.6 &.. & 11.9 &.. &.. &.. &.. & 100.0 & 100.0 & 100.0 \\
\hline Germany & 2009 & 96.6 & 88.5 &.. & 93.7 & 1.5 & 2.5 & 1.8 & 1.9 & 9.1 &.. & 4.5 &.. &.. &.. & .. & 100.0 & 100.0 & 100.0 \\
\hline Hungary & 2009 & 94.8 & 89.8 &.. & 93.2 & 0.9 & 0.7 & 0.9 & 3.6 & 8.1 &.. & 5.0 & 0.7 & 1.4 &.. & 0.9 & 100.0 & 100.0 & 100.0 \\
\hline Israel & 2009 & 89.1 & 85.7 &.. & 87.8 & 1.4 & 3.0 & 2.0 & 8.0 & 10.3 &.. & 8.9 & 1.5 & 1.0 &. & 1.3 & 100.0 & 100.0 & 100.0 \\
\hline Latvia & 2009 & 89.8 & 88.3 &.. & 89.1 & 1.9 & 1.2 & 1.6 & 8.3 & 10.5 &.. & 9.4 &.. &.. &.. & .. & 100.0 & 100.0 & 100.0 \\
\hline Lithuania & 2009 & 97.2 & 93.8 &.. & 95.7 & 0.3 & 0.5 & 0.4 & 2.6 & 5.7 &.. & 3.9 &.. &.. &.. &.. & 100.0 & 100.0 & 100.0 \\
\hline Malta & 2009 & 90.8 & 96.5 &.. & 92.1 & 1.2 & .. & 0.9 & 8.0 & 3.5 &.. & 7.0 &.. &.. &.. &.. & 100.0 & 100.0 & 100.0 \\
\hline Netherlands & 2009 & 95.8 & 93.9 &.. & 95.2 & 1.4 & 1.3 & 1.4 & 2.7 & 4.8 &.. & 3.4 &.. &.. &.. &.. & 100.0 & 100.0 & 100.0 \\
\hline Norway & 2009 & 94.2 & 92.6 &.. & 93.7 & 1.1 & 1.5 & 1.2 & 4.7 & 6.0 &.. & 5.1 &.. &.. &.. &.. & 100.0 & 100.0 & 100.0 \\
\hline Poland & 2008 & 98.7 & 97.8 &.. & 98.3 & 1.1 & 1.6 & 1.3 & 0.2 & 0.6 &.. & 0.4 &.. &.. &.. &.. & 100.0 & 100.0 & 100.0 \\
\hline Slovenia & 2009 & 92.5 & 92.3 &.. & 92.4 & 1.1 & 1.3 & 1.2 & 6.4 & 6.4 &.. & 6.4 &.. &.. & .. &.. & 100.0 & 100.0 & 100.0 \\
\hline Spain & 2009 & 96.3 & 95.9 &.. & 96.1 & 1.7 & 2.6 & 2.1 & 2.1 & 1.5 &.. & 1.8 &.. &.. &.. &.. & 100.0 & 100.0 & 100.0 \\
\hline $\begin{array}{l}\text { Chinese } \\
\text { Taipei } \\
\end{array}$ & 2009 & 94.5 & 96.3 & .. & 94.9 & 1.2 & 0.7 & 1.1 & .. & .. & .. & 4.0 & 4.3 & 3.1 &.. & 0.0 & 100.0 & 100.0 & 100.0 \\
\hline Turkey & 2009 & 93.6 & 91.7 &.. & 93.0 & 0.8 & 1.0 & 0.9 & 5.4 & 7.2 &.. & 6.0 & 0.1 & 0.2 & .. & 0.2 & 100.0 & 100.0 & 100.0 \\
\hline United States & 2008 & 89.9 & 89.4 &.. & 89.8 & 1.4 & 1.7 & 1.5 & 8.7 & 8.9 &.. & 8.7 &.. &.. &.. &.. & 100.0 & 100.0 & 100.0 \\
\hline
\end{tabular}

Notes:

*Data for Belgium, Germany, Hungary, the Netherlands and Spain refer to graduation years 1990 onwards.

*For Belgium and Malta, data for the 65-69 age class include doctorate holders aged 70 years and above.

*For Spain, there is limited coverage of doctorate holders for the years 2007 to 2009.

*Data for Turkey exclude foreign citizens.

${ }^{*}$ For the United States, data exclude doctorate holders who received their degree abroad and who received a doctorate in humanities.

Source: OECD, OECD/UNESCO Institute for Statistics/Eurostat data collection on careers of doctorate holders 2010. 
Annex table 2. Unemployment rates of doctorate holders, by field of study, 2009

\begin{tabular}{|c|c|c|c|c|c|c|c|c|c|}
\hline & $\begin{array}{l}\text { Referenc } \\
\text { e year }\end{array}$ & $\begin{array}{l}\text { Natural } \\
\text { sciences }\end{array}$ & $\begin{array}{l}\text { Engineerin } \\
\mathrm{g}\end{array}$ & $\begin{array}{l}\text { Medical } \\
\text { sciences }\end{array}$ & $\begin{array}{l}\text { Agricultur } \\
\text { al } \\
\text { Sciences }\end{array}$ & $\begin{array}{l}\text { Social } \\
\text { sciences }\end{array}$ & Humanities & $\begin{array}{l}\text { Unknow } \\
\text { n }\end{array}$ & Total \\
\hline Belgium & 2009 & 1.4 & 0.9 & 0.7 & 0.7 & 1.9 & 3.7 & 2.5 & 1.4 \\
\hline Croatia & 2009 & 0.4 & 0.0 & 1.5 & 1.0 & 1.1 & 0.5 & .. & 0.7 \\
\hline Denmark & 2008 & 0.6 & 0.1 & 0.4 & 1.0 & 0.4 & 1.1 &.. & 0.5 \\
\hline Finland & 2008 & 3.1 & 1.4 & 0.8 & 3.4 & 2.3 & 3.6 & 8.8 & 2.1 \\
\hline Hungary & 2009 & 0.5 & 0.9 & 1.1 & 0.0 & 0.0 & 2.8 & 5.6 & 0.9 \\
\hline Israel & 2009 & 2.2 &.. & 2.4 & 9.9 & 1.0 & 3.7 &.. & 2.0 \\
\hline Latvia & 2009 & 1.8 & 0.7 & 1.3 & 2.8 & 1.5 & 2.4 &.. & 1.6 \\
\hline Lithuania & 2009 & 0.2 & 0.3 & 0.6 & 0.0 & 0.3 & 0.7 &.. & 0.4 \\
\hline Malta & 2009 & 1.4 & 1.9 & 1.6 & 0.0 & 0.9 & 0.0 & .. & 0.9 \\
\hline Netherlands & 2009 & 1.7 & 1.3 & 0.6 & 1.7 & 1.3 & 3.9 &.. & 1.4 \\
\hline Spain & 2009 & 2.8 & 1.5 & 1.2 & 4.6 & 1.4 & 2.4 &.. & 2.1 \\
\hline Chinese Taipei & 2009 & 1.7 & 0.9 & 0.8 & 2.5 & 0.7 & 1.0 & 2.3 & 1.1 \\
\hline Turkey & 2009 & 0.7 & 0.8 & 0.8 & 1.7 & 1.2 & 0.2 &.. & 0.9 \\
\hline United States & 2008 & 1.7 & 1.6 & 1.5 & 1.6 & 1.1 &.. &.. & 1.5 \\
\hline
\end{tabular}

Notes:

${ }^{*}$ Data for Belgium, Germany, Hungary, the Netherlands and Spain refer to graduation years 1990 onwards.

*For Belgium and Malta, data for the 65-69 age class include doctorate holders aged 70 years and above.

*For Spain, there is limited coverage of doctorate holders for the years 2007 to 2009.

*Data for Turkey exclude foreign citizens.

${ }^{*}$ For the United States, data exclude doctorate holders who received their degree abroad and who received a doctorate in humanities.

Source: OECD, OECD/UNESCO Institute for Statistics/Eurostat data collection on careers of doctorate holders 2010. 
Annex table 3. Doctorate holders having changed jobs in the last 10 years by origin and destination sectors, 2009

\begin{tabular}{|c|c|c|c|c|c|c|c|c|c|c|c|c|c|c|}
\hline & \multirow[b]{2}{*}{$\begin{array}{l}\text { Previous } \\
\text { sector: }\end{array}$} & \multicolumn{6}{|c|}{ Employed as researchers in: } & \multicolumn{7}{|c|}{ Employed not as researchers in: } \\
\hline & & $\begin{array}{l}\text { Business } \\
\text { enterprises }\end{array}$ & Government & $\begin{array}{l}\text { Higher } \\
\text { education }\end{array}$ & $\begin{array}{l}\text { Private } \\
\text { non-profit }\end{array}$ & Unknown & Total & $\begin{array}{l}\text { Business } \\
\text { enterprises }\end{array}$ & Government & $\begin{array}{l}\text { Higher } \\
\text { education }\end{array}$ & $\begin{array}{c}\text { Private } \\
\text { non-profit }\end{array}$ & $\begin{array}{c}\text { other } \\
\text { education }\end{array}$ & Unknown & Total \\
\hline \multirow[t]{7}{*}{ Belgium } & BES & 22.1 & 1.4 & 4.1 & 1.6 & 0.7 & 29.8 & 29.5 & 5.5 & 2.7 & 4.9 & 1.6 & 0.5 & 44.8 \\
\hline & GOV & 1.4 & 3.2 & 1.4 & 0.5 & 0.0 & 6.3 & 2.2 & 7.1 & 0.5 & 0.5 & 0.5 & 0.0 & 10.9 \\
\hline & HES & 5.4 & 3.8 & 42.9 & 2.0 & 0.9 & 55.1 & 5.5 & 4.4 & 13.1 & 2.7 & 1.1 & 0.0 & 26.8 \\
\hline & PNP & 0.9 & 1.6 & 0.9 & 2.3 & 0.2 & 5.9 & 1.1 & 2.2 & 0.0 & 6.0 & 0.0 & 0.0 & 9.3 \\
\hline & Other educ. & 0.5 & 0.0 & 0.7 & 0.0 & 0.2 & 1.4 & 0.5 & 1.1 & 2.7 & 0.0 & 2.7 & 0.0 & 7.1 \\
\hline & Unknown & 0.0 & 0.0 & 1.6 & 0.0 & 0.0 & 1.6 & 0.5 & 0.0 & 0.0 & 0.5 & 0.0 & 0.0 & 1.1 \\
\hline & Total sectors & 30.2 & 9.9 & 51.5 & 6.3 & 2.0 & 100.0 & 39.3 & 20.2 & 19.1 & 14.8 & 6.0 & 0.5 & 100.0 \\
\hline \multirow[t]{7}{*}{ Bulgaria } & BES & 0.2 & 0.3 & 9.5 & 3.9 & 0.0 & 13.9 & 17.5 & 4.7 & 4.9 & 10.0 & 0.0 & 0.0 & 37.0 \\
\hline & GOV & 1.1 & 18.8 & 14.5 & 2.4 & 0.0 & 36.8 & 9.9 & 9.5 & 9.7 & 4.1 & 0.0 & 0.6 & 33.8 \\
\hline & HES & 1.3 & 5.8 & 26.3 & 0.0 & 0.0 & 35.6 & 0.0 & 0.0 & 2.7 & 3.4 & 0.0 & 1.5 & 7.6 \\
\hline & PNP & 0.0 & 1.1 & 1.6 & 1.4 & 0.0 & 4.2 & 3.4 & 2.6 & 5.3 & 4.7 & 0.0 & 0.0 & 16.1 \\
\hline & Other educ. & 2.2 & 0.0 & 6.8 & 0.0 & 0.0 & 9.0 & 0.0 & 0.0 & 0.0 & 0.0 & 2.8 & 0.0 & 2.8 \\
\hline & Unknown & 0.0 & 0.2 & 0.3 & 0.0 & 0.0 & 0.5 & 0.0 & 0.0 & 0.0 & 0.0 & 0.0 & 2.5 & 2.5 \\
\hline & Total sectors & 4.8 & 26.3 & 59.0 & 7.7 & 2.2 & 100.0 & 30.8 & 16.8 & 22.6 & 22.2 & 2.8 & 4.7 & 100.0 \\
\hline \multirow[t]{7}{*}{ Croatia } & BES & 1.5 & 4.0 & 14.1 & 0.0 & 0.0 & 19.6 & 25.4 & 1.5 & 9.5 & 0.0 & 0.0 & 0.0 & 36.7 \\
\hline & GOV & 2.2 & 11.6 & 19.4 & 0.0 & 0.0 & 33.2 & 10.4 & 18.4 & 10.0 & 4.7 & 1.7 & 0.0 & 44.9 \\
\hline & HES & 3.9 & 9.5 & 21.9 & 0.5 & 0.0 & 35.9 & 10.0 & 1.5 & 1.1 & 0.0 & 0.0 & 0.0 & 12.7 \\
\hline & PNP & 0.0 & 0.0 & 3.1 & 0.0 & 0.0 & 3.1 & 0.0 & 1.3 & 0.0 & 0.0 & 0.0 & 0.0 & 1.3 \\
\hline & Other educ. & 0.0 & 1.1 & 7.0 & 0.0 & 0.0 & 8.3 & 0.0 & 1.5 & 3.0 & 0.0 & 0.0 & 0.0 & 4.4 \\
\hline & Unknown & 0.0 & 0.0 & 0.0 & 0.0 & 0.0 & 0.0 & 0.0 & 0.0 & 0.0 & 0.0 & 0.0 & 0.0 & 0.0 \\
\hline & Total sectors & 7.5 & 26.3 & 65.6 & 0.5 & 0.1 & 100.0 & 45.8 & 24.2 & 23.5 & 4.7 & 1.7 & 0.0 & 100.0 \\
\hline \multirow[t]{7}{*}{ Hungary } & BES & 4.6 & 2.9 & 8.6 & 0.3 & 0.0 & 16.3 & 30.4 & 1.4 & 7.2 & 1.4 & 1.4 & 0.0 & 42.0 \\
\hline & GOV & 4.0 & 13.5 & 13.2 & 1.1 & 0.0 & 31.8 & 5.8 & 10.1 & 7.2 & 0.0 & 0.0 & 0.0 & 23.2 \\
\hline & HES & 3.4 & 13.2 & 27.8 & 1.1 & 0.0 & 45.6 & 5.8 & 5.8 & 11.6 & 1.4 & 0.0 & 0.0 & 24.6 \\
\hline & PNP & 0.3 & 0.3 & 1.4 & 0.3 & 0.0 & 2.3 & 0.0 & 0.0 & 1.4 & 4.3 & 0.0 & 0.0 & 5.8 \\
\hline & Other educ. & 0.0 & 0.3 & 3.7 & 0.0 & 0.0 & 4.0 & 0.0 & 1.4 & 2.9 & 0.0 & 0.0 & 0.0 & 4.3 \\
\hline & Unknown & 0.0 & 0.0 & 0.0 & 0.0 & 0.0 & 0.0 & 0.0 & 0.0 & 0.0 & 0.0 & 0.0 & 0.0 & 0.0 \\
\hline & Total sectors & 12.3 & 30.1 & 54.7 & 2.9 & 0.0 & 100.0 & 42.0 & 18.8 & 30.4 & 7.2 & 1.4 & 0.0 & 100.0 \\
\hline
\end{tabular}


DSTI/DOC(2013)4

\begin{tabular}{|c|c|c|c|c|c|c|c|c|c|c|c|c|c|c|}
\hline & \multirow[b]{2}{*}{$\begin{array}{l}\text { Previous } \\
\text { sector: }\end{array}$} & \multicolumn{6}{|c|}{ Employed as researchers in: } & \multicolumn{7}{|c|}{ Not employed as researchers in: } \\
\hline & & $\begin{array}{l}\text { Business } \\
\text { enterprises }\end{array}$ & Government & $\begin{array}{c}\text { Higher } \\
\text { education }\end{array}$ & $\begin{array}{c}\text { Private } \\
\text { non-profit }\end{array}$ & Unknown & Total & $\begin{array}{l}\text { Business } \\
\text { enterprises }\end{array}$ & Government & $\begin{array}{c}\text { Higher } \\
\text { education }\end{array}$ & $\begin{array}{c}\text { Private } \\
\text { non-profit }\end{array}$ & $\begin{array}{c}\text { other } \\
\text { education }\end{array}$ & Unknown & Total \\
\hline \multirow[t]{6}{*}{ Latvia } & BES & 7.5 & 3.1 & 21.0 & 0.0 & 0.0 & 31.6 & 32.8 & 1.7 & 2.3 & 0.0 & 0.0 & 0.0 & 36.8 \\
\hline & HES & 5.6 & 5.9 & 21.8 & 0.0 & 0.0 & 33.8 & 3.4 & 6.3 & 11.5 & 0.0 & 0.0 & 0.0 & 21.3 \\
\hline & PNP & 0.0 & 0.5 & 0.7 & 0.0 & 0.0 & 1.1 & 0.0 & 0.0 & 2.3 & 0.0 & 0.0 & 0.0 & 2.3 \\
\hline & Other educ. & 0.0 & 0.0 & 3.3 & 0.0 & 0.0 & 4.4 & 2.3 & 0.0 & 1.7 & 0.0 & 0.0 & 0.0 & 4.0 \\
\hline & Unknown & 0.0 & 0.0 & 0.0 & 0.0 & 0.0 & 0.0 & 0.0 & 0.0 & 0.0 & 0.0 & 0.0 & 0.0 & 0.0 \\
\hline & Total sectors & 15.6 & 22.5 & 59.8 & 0.5 & 1.6 & 100.0 & 51.1 & 25.3 & 23.6 & 0.0 & 0.0 & 0.0 & 100.0 \\
\hline \multirow[t]{7}{*}{ Lithuania } & BES & 7.8 & 2.6 & 12.9 & 0.0 & 0.0 & 23.3 & 23.6 & 4.9 & 6.1 & 0.0 & 1.2 & 0.0 & 35.8 \\
\hline & GOV & 4.2 & 9.9 & 17.9 & 0.0 & 0.0 & 32.0 & 6.9 & 15.8 & 3.7 & 0.0 & 0.0 & 0.0 & 26.4 \\
\hline & HES & 3.6 & 4.6 & 25.4 & 0.0 & 0.0 & 33.5 & 8.6 & 9.2 & 7.3 & 0.0 & 2.8 & 0.0 & 27.8 \\
\hline & PNP & 0.0 & 0.0 & 2.3 & 0.0 & 0.0 & 2.3 & 0.0 & 0.0 & 1.2 & 0.0 & 0.0 & 0.0 & 1.2 \\
\hline & Other educ. & 0.7 & 1.0 & 7.1 & 0.0 & 0.0 & 8.9 & 3.8 & 1.7 & 2.5 & 0.0 & 0.8 & 0.0 & 8.8 \\
\hline & Unknown & 0.0 & 0.0 & 0.0 & 0.0 & 0.0 & 0.0 & 0.0 & 0.0 & 0.0 & 0.0 & 0.0 & 0.0 & 0.0 \\
\hline & Total sectors & 16.3 & 18.1 & 65.6 & 0.0 & 0.0 & 100.0 & 42.9 & 31.7 & 20.7 & 0.0 & 4.7 & 0.0 & 100.0 \\
\hline \multirow{6}{*}{$\begin{array}{l}\text { Netherla } \\
\text { nds }\end{array}$} & GOV & 2.4 & 7.1 & 2.4 & 1.6 & 0.0 & 13.5 & 3.7 & 8.5 & 1.2 & 2.4 & 0.0 & 0.0 & 14.6 \\
\hline & HES & 9.5 & 4.0 & 23.8 & 5.6 & 0.0 & 43.7 & 7.3 & 3.7 & 7.3 & 3.7 & 1.2 & 0.0 & 23.2 \\
\hline & PNP & 3.2 & 2.4 & 3.2 & 7.1 & 0.0 & 16.7 & 2.4 & 2.4 & 1.2 & 13.4 & 0.0 & 0.0 & 20.7 \\
\hline & Other educ. & 0.0 & 0.0 & 0.8 & 0.0 & 0.8 & 2.4 & 0.0 & 1.2 & 0.0 & 0.0 & 2.4 & 0.0 & 4.9 \\
\hline & Unknown & 0.0 & 0.0 & 0.0 & 0.0 & 0.0 & 0.0 & 0.0 & 0.0 & 0.0 & 0.0 & 0.0 & 0.0 & 0.0 \\
\hline & Total sectors & 30.2 & 15.1 & 34.9 & 17.5 & 2.4 & 100.0 & 42.7 & 18.3 & 11.0 & 23.2 & 4.9 & 0.0 & 100.0 \\
\hline \multirow[t]{7}{*}{ Portugal } & BES & 2.0 & 1.3 & 20.7 & 0.4 & 0.0 & 24.3 & 3.4 & 2.9 & 18.9 & 0.8 & 0.0 & 0.0 & 26.0 \\
\hline & GOV & 0.3 & 4.3 & 30.1 & 1.0 & 0.0 & 35.8 & 0.0 & 0.7 & 14.1 & 0.0 & 3.5 & 0.0 & 18.3 \\
\hline & HES & 1.2 & 2.9 & 27.1 & 1.8 & 0.0 & 33.0 & 1.9 & 0.9 & 26.9 & 1.3 & 0.0 & 0.0 & 30.9 \\
\hline & PNP & 0.1 & 0.0 & 6.1 & 0.7 & 0.0 & 6.9 & 0.0 & 0.0 & 6.3 & 2.4 & 0.0 & 0.0 & 8.7 \\
\hline & Other educ. & 0.0 & 0.0 & 0.0 & 0.0 & 0.0 & 0.0 & 0.0 & 0.3 & 14.9 & 0.8 & 0.0 & 0.0 & 16.0 \\
\hline & Unknown & 0.0 & 0.0 & 0.0 & 0.0 & 0.0 & 0.0 & 0.0 & 0.0 & 0.0 & 0.0 & 0.0 & 0.0 & 0.0 \\
\hline & Total sectors & 3.7 & 8.5 & 83.9 & 3.9 & 0.0 & 100.0 & 5.3 & 4.8 & 81.1 & 5.4 & 3.5 & 0.0 & 100.0 \\
\hline
\end{tabular}




\begin{tabular}{|c|c|c|c|c|c|c|c|c|c|c|c|c|c|c|}
\hline & \multirow[b]{2}{*}{$\begin{array}{l}\text { Previous } \\
\text { sector: }\end{array}$} & \multicolumn{6}{|c|}{ Employed as researchers in: } & \multicolumn{7}{|c|}{ Not employed as researchers in: } \\
\hline & & $\begin{array}{l}\text { Business } \\
\text { enterprises }\end{array}$ & Government & $\begin{array}{c}\text { Higher } \\
\text { education }\end{array}$ & $\begin{array}{c}\text { Private } \\
\text { non-profit }\end{array}$ & Unknown & Total & $\begin{array}{l}\text { Business } \\
\text { enterprises }\end{array}$ & Government & $\begin{array}{c}\text { Higher } \\
\text { education }\end{array}$ & $\begin{array}{c}\text { Private } \\
\text { non-profit }\end{array}$ & $\begin{array}{c}\text { other } \\
\text { education }\end{array}$ & Unknown & Total \\
\hline \multirow[t]{7}{*}{ Romania } & BES & 4.3 & 3.3 & 16.1 & 0.0 & 0.0 & 23.7 & 11.3 & 5.2 & 7.7 & 0.6 & 1.5 & 0.0 & 26.3 \\
\hline & GOV & 0.9 & 7.9 & 14.3 & 0.0 & 0.0 & 23.1 & 2.7 & 15.6 & 7.3 & 0.5 & 0.6 & 0.0 & 26.6 \\
\hline & HES & 1.2 & 5.3 & 31.0 & 0.0 & 0.0 & 37.6 & 2.2 & 5.7 & 13.0 & 0.3 & 1.5 & 0.0 & 22.7 \\
\hline & PNP & 0.3 & 0.6 & 1.4 & 0.9 & 0.0 & 3.2 & 0.3 & 1.3 & 2.0 & 0.2 & 0.2 & 0.0 & 4.0 \\
\hline & Other educ. & 0.3 & 2.2 & 10.0 & 0.0 & 0.0 & 12.5 & 0.3 & 2.2 & 8.4 & 0.5 & 9.1 & 0.0 & 20.5 \\
\hline & Unknown & 0.0 & 0.0 & 0.0 & 0.0 & 0.0 & 0.0 & 0.0 & 0.0 & 0.0 & 0.0 & 0.0 & 0.0 & 0.0 \\
\hline & Total sectors & 7.1 & 19.3 & 72.7 & 0.9 & 0.0 & 100.0 & 16.8 & 30.0 & 38.4 & 2.0 & 12.9 & 0.0 & 100.0 \\
\hline \multirow{6}{*}{ Russia } & BES & 7.9 & 15.2 & 2.4 & 0.0 & 1.2 & 26.8 & 12.3 & 0.0 & 11.5 & 0.0 & 0.4 & 0.0 & 24.2 \\
\hline & GOV & 4.3 & 25.6 & 3.0 & 0.0 & 0.0 & 32.9 & 3.9 & 0.0 & 9.9 & 0.0 & 0.0 & 0.2 & 14.0 \\
\hline & HES & 1.8 & 11.0 & 6.1 & 0.0 & 0.6 & 19.5 & 5.1 & 0.0 & 34.5 & 0.0 & 0.0 & 0.0 & 39.6 \\
\hline & PNP & 0.0 & 1.8 & 0.0 & 0.0 & 0.0 & 1.8 & 0.2 & 0.0 & 0.8 & 0.0 & 0.0 & 0.0 & 1.0 \\
\hline & Other educ. & 0.0 & 3.7 & 0.0 & 0.0 & 0.0 & 3.7 & 0.8 & 0.0 & 8.4 & 0.0 & 0.4 & 0.0 & 9.7 \\
\hline & Unknown & 1.8 & 12.8 & 0.6 & 0.0 & 0.0 & 15.2 & 2.1 & 0.0 & 9.2 & 0.0 & 0.2 & 0.0 & 11.5 \\
\hline \multirow[t]{7}{*}{ Slovenia } & BES & 3.1 & 1.6 & 8.8 & 0.9 & 0.0 & 14.4 & 19.0 & 5.1 & 2.9 & 1.9 & 0.8 & 0.0 & 29.9 \\
\hline & GOV & 3.8 & 2.3 & 15.6 & 0.8 & 0.0 & 22.5 & 6.3 & 19.4 & 3.9 & 2.0 & 0.0 & 0.0 & 31.6 \\
\hline & HES & 20.7 & 9.6 & 23.4 & 0.9 & 0.0 & 55.6 & 15.6 & 11.4 & 4.9 & 0.8 & 1.2 & 0.0 & 34.0 \\
\hline & PNP & 1.1 & 0.8 & 1.6 & 0.0 & 0.0 & 3.5 & 0.0 & 0.0 & 0.0 & 0.0 & 0.0 & 0.0 & 0.0 \\
\hline & Other educ. & 0.0 & 0.0 & 3.3 & 0.0 & 0.0 & 3.3 & 1.7 & 0.8 & 0.8 & 0.0 & 1.2 & 0.0 & 4.6 \\
\hline & Unknown & 0.4 & 0.4 & 0.0 & 0.0 & 0.0 & 0.8 & 0.0 & 0.0 & 0.0 & 0.0 & 0.0 & 0.0 & 0.0 \\
\hline & Total sectors & 29.2 & 14.7 & 52.7 & 2.7 & 0.8 & 100.0 & 42.6 & 36.7 & 12.7 & 4.8 & 3.1 & 0.0 & 100.0 \\
\hline \multirow[t]{7}{*}{ Spain } & BES & 5.3 & 6.0 & 10.9 & 1.3 & 0.0 & 23.6 & 18.5 & 13.8 & 5.1 & 0.8 & 0.0 & 0.0 & 38.2 \\
\hline & GOV & 1.8 & 16.9 & 10.6 & 2.5 & 0.0 & 31.9 & 8.1 & 21.7 & 2.3 & 0.6 & 0.0 & 0.0 & 32.8 \\
\hline & HES & 2.7 & 8.4 & 22.0 & 1.4 & 0.0 & 34.6 & 6.0 & 11.8 & 4.6 & 1.3 & 0.0 & 0.0 & 23.8 \\
\hline & PNP & 1.2 & 3.8 & 3.4 & 1.5 & 0.0 & 9.9 & 1.7 & 2.1 & 0.7 & 0.8 & 0.0 & 0.0 & 5.2 \\
\hline & Other educ. & 0.0 & 0.0 & 0.0 & 0.0 & 0.0 & 0.0 & 0.0 & 0.0 & 0.0 & 0.0 & 0.0 & 0.0 & 0.0 \\
\hline & Unknown & 0.0 & 0.0 & 0.0 & 0.0 & 0.0 & 0.0 & 0.0 & 0.0 & 0.0 & 0.0 & 0.0 & 0.0 & 0.0 \\
\hline & Total sectors & 11.1 & 35.2 & 47.0 & 6.8 & 0.0 & 100.0 & 34.4 & 49.4 & 12.7 & 3.5 & 0.0 & 0.0 & 100.0 \\
\hline
\end{tabular}


DSTI/DOC(2013)4

\begin{tabular}{|c|c|c|c|c|c|c|c|c|c|c|c|c|c|c|}
\hline & \multirow[b]{2}{*}{$\begin{array}{l}\text { Previous } \\
\text { sector: }\end{array}$} & \multicolumn{6}{|c|}{ Employed as researchers in: } & \multicolumn{7}{|c|}{ Not employed as researchers in: } \\
\hline & & $\begin{array}{l}\text { Business } \\
\text { enterprises }\end{array}$ & Government & $\begin{array}{c}\text { Higher } \\
\text { education }\end{array}$ & $\begin{array}{c}\text { Private } \\
\text { non-profit }\end{array}$ & Unknown & Total & $\begin{array}{l}\text { Business } \\
\text { enterprises }\end{array}$ & Government & $\begin{array}{c}\text { Higher } \\
\text { education }\end{array}$ & $\begin{array}{c}\text { Private } \\
\text { non-profit }\end{array}$ & $\begin{array}{l}\text { other } \\
\text { education }\end{array}$ & Unknown & Total \\
\hline \multirow[t]{6}{*}{ Turkey } & BES & 3.8 & 0.7 & 14.4 & 0.0 & 0.0 & 18.9 & 19.7 & 3.8 & 6.0 & 0.4 & 0.5 & 0.0 & 30.3 \\
\hline & GOV & 1.7 & 4.9 & 23.9 & 0.1 & 0.0 & 30.7 & 17.5 & 14.4 & 9.3 & 0.1 & 0.2 & 0.0 & 41.5 \\
\hline & HES & 1.9 & 2.2 & 38.0 & 0.0 & 0.0 & 42.2 & 4.9 & 5.2 & 13.9 & 0.2 & 0.3 & 0.0 & 24.5 \\
\hline & PNP & 0.0 & 0.0 & 0.6 & 0.0 & 0.0 & 0.6 & 0.4 & 0.5 & 1.0 & 0.0 & 0.3 & 0.0 & 2.2 \\
\hline & Unknown & 0.0 & 0.0 & 0.0 & 0.0 & 0.0 & 0.0 & 0.0 & 0.0 & 0.0 & 0.0 & 0.0 & 0.0 & 0.0 \\
\hline & Total sectors & 7.4 & 8.6 & 83.8 & 0.1 & 0.0 & 100.0 & 43.3 & 23.9 & 30.6 & 0.9 & 1.2 & 0.0 & 100.0 \\
\hline
\end{tabular}

Notes:

*Data for Belgium, Hungary, the Netherlands and Spain refer to graduation years 1990 onwards

*For Belgium and the Russian Federation, data for the 65-69 age class include doctorate holders aged 70 years and above.

*For Romania, unemployed and inactive doctorate holders are underestimated.

${ }^{*}$ For the Russian Federation, data relate only to those doctoral graduates employed as researchers and teachers.

*For Spain, there is limited coverage of doctorate holders for the years 2007 to 2009.

*Data for Turkey exclude foreign citizens.

Source: OECD, OECD/UNESCO Institute for Statistics/Eurostat data collection on careers of doctorate holders 2010. 


\section{DSTI/DOC(2013)4}

Annex table 4. Ten top destination countries of national citizens with a doctorate having lived/stayed abroad in the past ten years, 2009

\begin{tabular}{|c|c|c|c|c|c|c|c|}
\hline & Belgium & Bulgaria & Croatia & Hungary & Israel & Lithuania & Latvia \\
\hline 1 & USA & DEU & USA & USA & USA & USA & USA \\
\hline 2 & FRA & USA & DEU & DEU & GBR & SWE & DEU \\
\hline 3 & GBR & FRA & ITA & GBR & FRA & DEU & SWE \\
\hline 4 & NLD & GBR & AUT & FRA & CAN & BEL & FRA \\
\hline 5 & DEU & AUT & GBR & NLD & AUS & POL & GBR \\
\hline 6 & CAN & GRC & FRA & AUT & ITA & GBR & JPN \\
\hline 7 & $\mathrm{CHE}$ & BEL & CHE & CHE & DEU & FIN & EST \\
\hline 8 & AUS & ESP & AUS & ITA & CHE & DNK & AUT \\
\hline 9 & ITA & RUS & ISR & BEL & NLD & LVA & BEL \\
\hline \multirow[t]{2}{*}{10} & ESP & ITA & RUS & CAN & RUS & CZE & ESP \\
\hline & Malta & Netherlands & Poland & Portugal & Romania & Slovenia & Sweden \\
\hline 1 & GBR & USA & DEU & GBR & FRA & USA & USA \\
\hline 2 & ITA & GBR & USA & USA & DEU & DEU & GBR \\
\hline 3 & USA & DEU & GBR & ESP & USA & GBR & DNK \\
\hline 4 & DEU & AUS & ITA & FRA & ITA & ITA & NOR \\
\hline 5 & CAN & BEL & FRA & DEU & GBR & AUT & DEU \\
\hline 6 & BEL & CAN & SWE & NLD & BEL & FRA & RUS \\
\hline 7 & AUS & $\mathrm{CHE}$ & BEL & ITA & ESP & CHE & FRA \\
\hline 8 & FRA & FRA & CAN & $\mathrm{CHE}$ & JPN & NLD & IRQ \\
\hline 9 & NLD & ITA & JPN & BRA & CHE & ESP & CHE \\
\hline 10 & $\mathrm{CHE}$ & SWE & AUT & SWE & NLD & BEL & FIN \\
\hline
\end{tabular}

Notes:

"Data for Belgium, Hungary and the Netherlands refer to graduation years 1990 onwards.

*For Romania, unemployed and inactive doctorate holders are underestimated.

*For the Russian Federation, data relate only to those doctoral graduates employed as researchers and teachers.

${ }^{*}$ For Sweden, the population includes employed doctorate holders only.

Source: OECD, OECD/UNESCO Institute for Statistics/Eurostat data collection on careers of doctorate holders 2010. 
Annex table 5. Reasons given by national citizens with a doctorate for returning to the home country, 2009

\begin{tabular}{|c|c|c|c|c|c|c|c|c|c|}
\hline & $\begin{array}{c}\text { Reference } \\
\text { year }\end{array}$ & $\begin{array}{c}\text { Completion } \\
\text { of } \\
\text { doctorate }\end{array}$ & $\begin{array}{c}\text { End of } \\
\text { postdoc or job } \\
\text { contract } \\
\text { abroad }\end{array}$ & $\begin{array}{l}\text { Other job } \\
\text { related or } \\
\text { economic } \\
\text { factors }\end{array}$ & $\begin{array}{l}\text { Academic } \\
\text { factors }\end{array}$ & $\begin{array}{l}\text { Family or } \\
\text { personal } \\
\text { reasons }\end{array}$ & $\begin{array}{l}\text { Political or } \\
\text { other reason }\end{array}$ & Unspecified & Total \\
\hline Belgium & 2009 & 5.2 & 16.6 & 24.7 & 19.3 & 33.6 & 0.6 & .. & 100.0 \\
\hline Bulgaria & 2009 & 7.9 & 0.0 & 24.1 & 58.7 & 6.9 & 1.7 & 0.8 & 100.0 \\
\hline Croatia & 2009 & 20.7 & 3.6 & 18.3 & 26.7 & 30.7 & .. & .. & 100.0 \\
\hline Hungary & 2009 & 12.7 & 2.1 & 34.4 & 39.0 & 9.9 & 1.0 & 0.8 & 100.0 \\
\hline Israel & 2009 & 5.5 & 1.0 & 24.3 & 55.7 & 12.0 & 0.0 & 1.5 & 100.0 \\
\hline Latvia & 2009 & 8.0 & 32.8 & 22.4 & 11.0 & 24.7 & 1.0 & .. & 100.0 \\
\hline Lithuania & 2009 & 12.7 & 1.7 & 40.9 & 37.0 & 6.6 & 1.2 & .. & 100.0 \\
\hline Malta & 2009 & 34.9 & 4.6 & 22.0 & 5.5 & 32.1 & 0.9 & .. & 100.0 \\
\hline Netherlands & 2009 & 8.1 & 14.9 & 28.5 & 25.7 & 22.2 & 0.6 & .. & 100.0 \\
\hline Portugal & 2009 & 18.0 & 3.0 & 24.9 & 39.1 & 13.4 & 1.5 & .. & 100.0 \\
\hline Romania & 2008 & 23.6 & 15.8 & 21.3 & 14.1 & 23.4 & 1.8 & .. & 100.0 \\
\hline Spain & 2009 & 11.1 & 15.1 & 21.8 & 13.2 & 27.9 & 10.9 &.. & 100.0 \\
\hline Turkey & 2009 & 11.6 & 10.6 & 8.8 & 26.1 & 14.6 & 7.5 & 20.8 & 100.0 \\
\hline
\end{tabular}

Notes:

*Data for Belgium, Hungary, the Netherlands and Spain refer to graduation years 1990 onwards.

*For Belgium and Malta, data for the 65-69 age class include doctorate holders aged 70 years and above.

*For Romania, unemployed and inactive doctorate holders are underestimated.

*For Spain, there is limited coverage of doctorate holders for the years 2007 to 2009.

Source: OECD, OECD/UNESCO Institute for Statistics/Eurostat data collection on careers of doctorate holders 2010. 
Annex table 6. Reasons given by national citizens with a doctorate for intended mobility abroad, 2009

\begin{tabular}{|c|c|c|c|c|c|c|c|c|c|}
\hline & $\begin{array}{l}\text { Reference } \\
\text { year }\end{array}$ & $\begin{array}{l}\text { Completion } \\
\text { of doctorate }\end{array}$ & $\begin{array}{c}\text { End of } \\
\text { postdoc or job } \\
\text { contract } \\
\text { abroad } \\
\end{array}$ & $\begin{array}{c}\text { Other job } \\
\text { related or } \\
\text { economic } \\
\text { factors } \\
\end{array}$ & $\begin{array}{l}\text { Academic } \\
\text { factors }\end{array}$ & $\begin{array}{c}\text { Family or } \\
\text { personal } \\
\text { reasons }\end{array}$ & $\begin{array}{l}\text { Political or } \\
\text { other } \\
\text { reason }\end{array}$ & Unspecified & Total \\
\hline Belgium & 2009 & 1.0 & 11.1 & 35.2 & 38.0 & 13.4 & 1.3 & 0.0 & 100.0 \\
\hline Bulgaria & 2009 & 0.1 & 1.7 & 34.9 & 37.3 & 18.0 & 6.8 & 1.1 & 100.0 \\
\hline Hungary & 2009 & 3.9 & 0.0 & 36.4 & 45.3 & 11.8 & 1.3 & 1.3 & 100.0 \\
\hline Latvia & 2009 & 0.0 & 10.7 & 39.5 & 28.2 & 21.7 & 0.0 & 0.0 & 100.0 \\
\hline Lithuania & 2009 & 3.6 & 1.1 & 47.3 & 33.7 & 13.8 & 0.5 & 0.0 & 100.0 \\
\hline Malta & 2009 & 0.0 & 0.0 & 34.5 & 46.6 & 19.0 & 0.0 & 0.0 & 100.0 \\
\hline Netherlands & 2009 & 0.0 & 10.5 & 31.6 & 42.1 & 15.8 & 0.0 & 0.0 & 100.0 \\
\hline Portugal & 2009 & 0.3 & 6.3 & 19.1 & 64.1 & 9.8 & 0.4 & 0.0 & 100.0 \\
\hline Romania & 2008 & 4.2 & 2.4 & 34.2 & 36.9 & 19.7 & 2.7 & 0.0 & 100.0 \\
\hline Spain & 2009 & 0.0 & 10.0 & 16.0 & 54.1 & 9.3 & 10.6 & 0.0 & 100.0 \\
\hline Turkey & 2009 & 0.0 & 8.6 & 11.6 & 57.1 & 13.3 & 9.4 & 0.0 & 100.0 \\
\hline
\end{tabular}

Notes:

*Data for Belgium, Hungary, the Netherlands and Spain refer to graduation years 1990 onwards.

*For Belgium, data for the 65-69 age class include doctorate holders aged 70 years and above.

*For Romania, unemployed and inactive doctorate holders are underestimated.

*For Spain, there is limited coverage of doctorate holders for the years 2007 to 2009

Source: OECD, OECD/UNESCO Institute for Statistics/Eurostat data collection on careers of doctorate holders 2010 
Annex table 7. Number of foreign born doctorate holders residing in the United States by country of birth and citizenship, 2000 Census and 2005-2009 American Community Survey

\begin{tabular}{|c|c|c|c|c|}
\hline \multirow[b]{2}{*}{ Country of birth } & \multicolumn{2}{|c|}{2000 Census } & \multicolumn{2}{|c|}{$\begin{array}{c}\text { American Community } \\
\text { Survey (2005-2009 } \\
\text { average) }\end{array}$} \\
\hline & $\begin{array}{l}\text { Number of } \\
\text { foreign born }\end{array}$ & $\begin{array}{l}\text { of which: } \\
\text { with US } \\
\text { citizenship }\end{array}$ & $\begin{array}{l}\text { Number of } \\
\text { foreign born }\end{array}$ & $\begin{array}{l}\text { of which: } \\
\text { with US } \\
\text { citizenship }\end{array}$ \\
\hline Argentina & 3896 & 2068 & 5950 & 2628 \\
\hline Australia & 3201 & 726 & 4233 & 1507 \\
\hline Austria & 3119 & 1980 & 3243 & 1948 \\
\hline Belgium & 1569 & 651 & 2514 & 996 \\
\hline Brazil & 3105 & 900 & 4730 & 1334 \\
\hline Bulgaria & 1543 & 335 & 1905 & 791 \\
\hline Canada & 19485 & 9355 & 24660 & 11843 \\
\hline Chile & 1608 & 855 & 1817 & 1093 \\
\hline China & 63283 & 25143 & 97891 & 39937 \\
\hline Croatia & 753 & 448 & 899 & 493 \\
\hline Czech Republic & .. & .. & 1331 & 611 \\
\hline Denmark & 860 & 282 & 1357 & 425 \\
\hline Estonia & 346 & 264 & 242 & 208 \\
\hline $\begin{array}{l}\text { Finland } \\
\text { Former }\end{array}$ & 745 & 173 & 875 & 304 \\
\hline Czechoslovakia & 2696 & 1799 & 3021 & 1718 \\
\hline France & 7935 & 2801 & 10752 & 4104 \\
\hline Germany & 22333 & 11208 & 26829 & 13589 \\
\hline Greece & 3772 & 2177 & 4812 & 3164 \\
\hline Hungary & 3395 & 2516 & 3263 & 2227 \\
\hline Iceland & 226 & 89 & 365 & 128 \\
\hline India & 46886 & 21201 & 63964 & 34817 \\
\hline Indonesia & 1094 & 661 & 1369 & 794 \\
\hline Ireland & 2535 & 1305 & 2821 & 1501 \\
\hline Israel & 4220 & 2766 & 5686 & 3327 \\
\hline Italy & 7061 & 3801 & 8309 & 3964 \\
\hline Japan & 8835 & 2591 & 11616 & 4103 \\
\hline Latvia & 746 & 642 & 777 & 711 \\
\hline Lithuania & 677 & 418 & 1178 & 667 \\
\hline Mexico & 8812 & 3707 & 11924 & 5761 \\
\hline Netherlands & 3814 & 1637 & 3849 & 1572 \\
\hline New Zealand & 1080 & 316 & 1421 & 636 \\
\hline Norway & 846 & 388 & 833 & 294 \\
\hline Poland & 7008 & 4509 & 7776 & 5283 \\
\hline Portugal & 677 & 361 & 902 & 507 \\
\hline Romania & 3045 & 1747 & 5342 & 2804 \\
\hline Russia & 13124 & 4734 & 17763 & 10298 \\
\hline Slovak Republic & .. & .. & 668 & 179 \\
\hline Slovenia & .. & .. & 1604 & 894 \\
\hline South Africa & 2202 & 1228 & 3452 & 1922 \\
\hline South Korea & 16634 & 7159 & 28796 & .. \\
\hline Spain & 3766 & 1032 & 5054 & 1870 \\
\hline Sweden & 1803 & 655 & 2104 & 819 \\
\hline Switzerland & 2578 & 1074 & 2723 & 1293 \\
\hline Chinese Taipei & 18915 & 12525 & 22155 & 16581 \\
\hline Turkey & 3273 & 1650 & 5849 & 3002 \\
\hline United Kingdom & 23652 & 9717 & 28122 & 12545 \\
\hline Total above & 327153 & 149594 & 444747 & 204402 \\
\hline Grand total & 442323 & & 600813 & \\
\hline
\end{tabular}

Source: OECD, Database on immigrants in the OECD countries, 2012. 